Ismael Souza

\title{
Cristão secularizado: contribuições de Hans Küng para viver a fé cristã no mundo de secularização
}

\section{Dissertação de Mestrado}

Dissertação apresentada como requisito parcial para obtenção do grau de Mestre pelo Programa de Pós-graduação em Teologia do Departamento de Teologia da PUC-Rio.

Orientador: Prof. Joel Portella Amado

Rio de Janeiro Setembro de 2008 
Ismael Souza

Cristão secularizado: contribuições de Hans Küng para vivencia da fé cristã no mundo de secularização

Dissertação apresentada como requisito parcial para obtenção do grau de Mestre pelo Programa de Pós-graduação em Teologia do Centro de Teologia e Ciências Humanas da PUC-Rio. Aprovada pela Comissão Examinadora abaixo assinada.

\author{
Prof. Joel Portella Amado \\ Orientador \\ Departamento de Teologia - PUC-Rio
}

Prof. Abimar Oliveira de Moraes Departamento de Teologia - PUC-Rio

Prof. Marcus Barbosa Guimarães

Seminário Paulo VI

Profa. Denise Berruezo Portinari Coordenadora Setorial de Pós-Graduação e Pesquisa do Centro de Teologia e Ciências Humanas - PUC-Rio.

Rio de Janeiro, 03 de setembro de 2012 
Todos os direitos reservados. É proibida a reprodução total ou parcial do trabalho sem a autorização da universidade, do autor e do orientador.

\section{Ismael Souza}

Bacharel em Teologia. Licenciatura e Especialização em Filosofia. Licenciatura Plena em Educação Física. Atua na área da pastoral, no diálogo ecumênico, interreligioso e da teologia cristã com a Modernidade. Apresentou artigos em diversos congressos na área de experiência religiosa, ciência e religião.

Ficha Catalográfica

Souza, Ismael

Cristão secularizado: contribuições de Hans Kung para viver a fé cristã no mundo de secularização / Ismael Souza ; orientador: Joel Portella Amado. - 2012. $167 \mathrm{f}$. ; $30 \mathrm{~cm}$

Dissertação (mestrado)-Pontifícia Universidade Católica do Rio de Janeiro, Departamento de Teologia, 2012.

Inclui bibliografia

1. Teologia - Teses. 2. Ateísmo. 3. Ciência. 4. Cristianismo. 5. Küng, Hans. 6. Modernidade. 7. Razão. 8. Pastoral. 9. Secularização. I. Amado, Joel Portella. II. Pontifícia Universidade Católica do Rio de Janeiro. Departamento de Teologia. III. Título.

CDD: 200 
Para minha esposa Verônica, meus filhos Maria Clara e Antônio Pedro, Pelo apoio, carinho e confiança. 


\section{Agradecimentos}

A Deus pelo fôlego de vida.

Ao meu orientador Professor Joel Portella Amado pelo estímulo e parceria para a realização deste trabalho.

Ao CAPES e à PUC-Rio, pelos auxílios concedidos, sem os quais este trabalho não poderia ter sido realizado.

Ao coordenador do Departamento, Abimar Oliveira Moraes, por toda atenção e dedicação.

Aos amigos do departamento de teologia Sérgio Albuquerque Damião e Jussara Maria de Oliveira, pela disponibilidade.

Aos meus colegas da PUC-Rio.

Aos professores que participaram da Comissão examinadora.

A todos os professores e funcionários do Departamento pelos ensinamentos e pela ajuda.

A todos os amigos e familiares que de uma forma ou de outra me estimularam ou me ajudaram. 


\section{Resumo}

Souza, Ismael; Amado, Joel Portella. Cristão secularizado: contribuições de Hans Küng para viver a fé cristã no mundo de secularização. Rio de Janeiro, 2012. 167p. Dissertação de Mestrado - Departamento de Teologia, Pontifícia Universidade Católica do Rio de Janeiro.

O processo de secularização do mundo ocidental trouxe, em sua esteira, diversas implicações teológico-pastorais para o cristianismo. Diante desta realidade, as Igrejas cristãs e cristãos necessitam de articulação para apresentar à seus contemporâneos a mensagem de Jesus de Nazaré de forma contextualizada. Com o objetivo de encontrar um caminho lúcido para responder às interpelações da sociedade secularizada, esta pesquisa recorreu às reflexões do teólogo Hans Küng, que permitiu responder as implicações e firmar a convicção à fé cristã e, sua relevância na atualidade e futuro.

\section{Palavras-chave}

Teologia; Ateísmo; Ciência; Cristianismo; Küng, Hans; Modernidade; Razão; Pastoral; Secularização. 


\section{Abstract}

Souza, Ismael; Amado, Joel Portella (Advisor). Secularized Christian: Contributions of Hans Kung to live a the Christian faith in a world of secularization. Rio de Janeiro, 2012. 167p. MSc. Dissertation Departamento de Teologia, Pontifícia Universidade Católica do Rio de Janeiro.

The process of secularization in the Western World brought, in its wake, several pastoral theological implications for Christianity. Faced by this reality, the Christian churches need to be articulated to be able to show the message of Jesus Christ from Nazareth in a coherent, mature and contextualized manner to their contemporaries. In order to find a lucid path to answer the questioning of a secularized society, this research made use of contributions by Hans Kung the theologian, allowing to clear up the Christian faith nowadays. Following this will be possible to find a good reflection about the secularization and current religious effervescence allowing the extreme conviction of a necessary and relevant Christian message in the modern world. Closing this exposure with pastoral theological proposals to the present time and a very soon explanation about the future of Christianity.

\section{Keywords}

Theology; Atheism; sciency; cristianism; Küng, Hans; Modernity; reason; pastoral; sécularisation. 


\section{Sumário}

1. Introdução 10

2. Secularização: da genealogia às implicações teológico-pastorais 14

2.1. Genealogia, panorama histórico e significado

2.2. Os paradigmas da sociologia da religião e as condições de crença em Hervieu-Léger

2.3. Charles Taylor: o complexo processo da secularização 45

2.4. Um olhar panorâmico $\quad 55$

2.5. Implicações teológico-pastorais $\quad 57$

2.5.1. Ciência versus religião: imanência versus transcendência 58

2.5.2. Razão versus fé: oposição ser humano versus Deus 59

2.5.3. A repressão da religião e da expressão religiosa 61

2.5.4. Modos pós-modernos de crítica 61

2.5.5. Posturas intrínsecas do ser cristão e suas instituições 62

2.5.6. O grande desafio: uma proposta de orientação cristã 65

2.5.7. A necessidade do diálogo ecumênico inter-religioso 66

2.5.8. A emergência de um ethos mundial para justiça e paz 66

3. Hans Küng: trajetória e reflexões de um teólogo ecumênico 68

3.1. Traços biográficos 68

3.2. A visão integral do ser humano: determinismo versus liberdade 74

$\begin{array}{ll}\text { 3.3. A religião na atualidade } & 76\end{array}$

3.4. O ethos fundamental 78

$\begin{array}{ll}\text { 3.5. Um olhar para o ateísmo moderno } & 79\end{array}$

3.6. A escatologia em Hans Küng 84 


\section{Sumário}

3.6.1. Morte, eternidade e o céu da fé: sentido e significado 84

3.6.2. As representações bíblicas e científicas do fim 92

3.6.3. O destino da alma 94

3.6.4. A ressurreição do corpo e a ascensão de Cristo 96

37. Críticas e defesas a Hans Küng 100

4. Hans Küng: contribuições para vivência da fé cristã no mundo de secularização

4.1. A legitimação do cristianismo no mundo secular 106

$\begin{array}{ll}\text { 4.2. Considerações pastorais } & 108\end{array}$

4.3. Respostas e interpelações às implicações teológico-pastorais 110

4.3.1. Contributos à ciência versus religião: abertura dialógica 110

4.3.2 Contributos à razão versus fé: o ser humano e Deus 122

4.3.3. Resposta à repressão da religião e das expressões religiosas 128

4.4. Interpelação aos modos pós-modernos de críticas 131

4.5. Contributos ao ser cristão e suas instituições 132

4.6. A proposta de orientação básica cristã para a sociedade 139

4.7. O estabelecimento do diálogo ecumênico e inter-religioso 142

4.8. O ethos mundial para justiça e paz 146

4.9. Hans Küng e a América Latina 149

5. Conclusão 152

6. Referências Bibliográficas 162

7. Sites Web apresentados 167 


\section{Introdução}

$\mathrm{Na}$ contemporaneidade é notória a observação dos processos de globalização, secularização e queda das utopias, principalmente no mundo ocidental. Cada um destes fenômenos, com suas características, influenciam o ser humano em seus ideais, pensamentos, aspirações e ações.

Com o desdobramento destes e outros processos, nada fica de fora de possíveis transformações. E neste terreno instável encontram-se também a religião, as experiências e as expressões religiosas.

Desta realidade infere-se a necessidade de conhecer as características do nosso tempo. Sendo, geralmente, necessário para uma compreensão consciente, reflexiva e elucidativa. Podendo ser imprescindível um regressar, o quanto e quando possível, até a origem de tais características. Quando essa dimensão investigativa de passado e presente se torna possível, nas mais brandas das hipóteses, será possível a conscientização para não empreendermos os mesmos erros do passado, em busca de um salutar presente e futuro.

Hoje, para ser ter uma compreensão adequada da época em que se vive e seu impacto na sociedade, devem-se ler os sinais do tempo, que poderá possibilitar perceber em que direção se move a nova orientação cognitiva fundamental do homem diante da radical revolução de padrões da civilização ocidental. $^{1}$

É necessário observar que "ler os sinais do tempo não é uma questão de olhar para o mundo a partir de fora, como se não fizéssemos parte dele. Nós estamos inseparavelmente integrados na sua rede de relações (...)"2. Esta questão se torna complexa devido aos condicionamentos já atingidos pela atual cosmovisão.

Segundo Nolan, os sinais do tempo são extremamente complexos, pois estão em constantes mutações, até um olhar de relance, hoje, permitirá ver que são, no mínimo, assustadores. São ambíguos, parecendo mover-se em várias direções ao mesmo tempo. São indicadores do futuro, não como clareza e

\footnotetext{
${ }^{1}$ Cf. BOLAN, Valmor. Sociologia da Secularização: a composição de um novo modelo cultural. Petrópolis: Vozes, 1972, p. 11.

${ }^{2}$ NOLAN, Albert. Jesus hoje: uma espiritualidade de liberdade radical. São Paulo: Paulinas, 2008, p. 17.
} 
definição para onde vamos, mas pelo fato de serem desafiadores. ${ }^{3} \mathrm{O}$ que devemos evitar nesta leitura hodierna "é a imposição de nossas ideias preconcebidas sobre a realidade de hoje. O nosso objetivo deve ser enfrentar a verdade em relação àquilo que está verdadeiramente acontecendo... quer isso nos agrade, quer não"4.

Um dos sinais do nosso tempo que ocupará esta pesquisa será o fenômeno da secularização do Ocidente. Tal escolha justifica-se devido ao fato do mundo ocidental sentir "com profundidade e certa perplexidade e angústia o crescente fenômeno da secularização, que se manifesta, às vezes, com força conflitiva nas estruturas tradicionais da organização humana" ${ }^{, 5}$. Principalmente no seu impacto "no tradicional relacionamento da civilização com o que convencionou-se chamar de "regime de cristandade""6.

Compreender o que significa secularização é crucial. A realidade da secularização se impôs de tal forma, que atinge com seus resultados diversas áreas da atividade humana. A cultura, educação, economia, política, tecnologia e diversas outras apresentam hoje em sua constituição reflexos desta realidade, não ficando de fora, mas intimamente relacionada a religião.

A relevância da compreensão do tema secularização continua ainda pertinente para o diálogo entre a Igreja e sua pastoral com a sociedade contemporânea, já que muitas características de uma sociedade secularizada trazem consigo profundas implicações teológico-pastorais.

Desde seu surgimento a fé cristã, levando em consideração cada período da história, foi e continua a ser interpelada. Esta fé necessita responder de forma coerente e significativa àqueles (as) que a ela perguntam. Desta forma, conhecer o seu próprio tempo é necessário para que o cristão possa apresentar a fé em Jesus Cristo de forma contextualizada e coerente para seus contemporâneos. Porém, esta postura da fé cristã torna-se mais complexa e desafiadora devido às transformações que ocorreram e ainda ocorrem oriundas do processo de secularização do Ocidente.

Esta pesquisa abordará a secularização a partir da modernidade, partindo do contexto Europeu, já que, no mundo Latino Americano, a religião ainda possui

\footnotetext{
${ }^{3}$ Cf. Ibid., p. 23.

${ }^{4}$ Ibid., p. 23.

${ }^{5}$ BOLAN, Valmor, op. cit., p. 17.

${ }^{6}$ Ibid, p. 23.
} 
sua representação na sociedade. No entanto, mesmo que a realidade latina americana seja diferente, os efeitos da secularização já se fazem presentes em nosso espaço de vida na contemporaneidade.

Não há dúvida que hoje se vive numa época secular. O que se coloca em discussão é o processo histórico de sua origem, a demarcação de seus limites e a extensão de seus resultados. Observando esta complexidade, há cerca de 40 anos, Comblin esclarece que o "conceito de secularização é relativamente nebuloso. Suas fronteiras não são bem delimitadas"7.

Hoje, o "tema secularização se impôs de maneira surpreendente à reflexão cristã. Bastaram alguns anos para transformá-lo em uma espécie de encruzilhada para a qual convergem os mais agudos problemas da atualidade cristã" ${ }^{\prime 8}$. Assim, na compreensão de Comblin, "se tornou impossível fazer teologia sem falar de secularização"9.

Devido esta complexidade, será necessário esclarecer em que consiste, o mais especificamente possível, o processo de secularização e responder as implicações teológico-pastorais advindas de sua esteira, utilizando-se para isso as reflexões de Hans Küng.

Para este propósito, será necessário, no segundo capítulo, verificar a genealogia da secularização, seus significados no desenrolar da história e a legitimação deste termo. Examinar os paradigmas da sociologia da religião e as condições de crença na contemporaneidade em Danièle Hervieu-Léger. Elucidar, utilizando-se de Charles Taylor, com sua análise histórico-descritiva do complexo processo da secularização do mundo ocidental, que este processo não pode ser explicado unicamente pela tese da secularização que enfatiza o fenômeno apenas pelo declínio do religioso. Apresentar algumas descrições das implicações teológico-pastorais que interpelam o cristianismo, advindas do processo estudado. Implicações que serão interpeladas e respondidas no capítulo quatro.

O terceiro capítulo apresentará os traços biográficos, o pensamento e teologia de Hans Küng. Possibilitando uma compreensão global das reflexões deste teólogo em relação a temas fundamentais referentes ao ser humano, a religião, a ética, um breve olhar para emersão das diversas formas de ateísmo

\footnotetext{
${ }^{7}$ COMBLIN, José. Mitos e realidade da secularização. São Paulo: Herder, 1970, p. 6-7

${ }^{8}$ Ibid., p. 1.

${ }^{9}$ Ibid., p. 1.
} 
oriundos da Modernidade e ainda presentes na atualidade, sua escatologia e as possíveis críticas e defesas a este teólogo.

O quarto capítulo apresentará contribuições de Hans Küng para a vivência da fé cristã no mundo de secularização. Utilizando reflexões deste teólogo para interpelar e responder as implicações teológico-pastorais, que foram levantadas no primeiro capítulo. Principalmente, enfatizando o debate entre ciência e religião, entre razão e fé, a repressão da religião e das expressões religiosas pela psicanálise, psicologia e psicoterapia. Após interpelar os modos de críticas pósmodernos, se apresentará propostas para a estrutura interna das Igrejas cristãs e para o ser cristão individualmente, uma proposta de orientação básica cristã para a sociedade e a necessidade do estabelecimento do diálogo ecumênico. Em seguida será apresentada a necessidade do estabelecimento de um ethos mundial para justiça e paz entre as religiões e nações, encerrando com uma aproximação de Hans Küng com a América Latina.

O objetivo final será proporcionar, através das contribuições de Hans Küng, um esclarecimento para a fundamentação e vivência da fé cristã na atual sociedade, e apresentar o significado de ser cristão secularizado.

No decorrer destas incumbências acadêmicas, foi percebida a possibilidade das lacunas que esta pesquisa poderá apresentar. Fato identificado durante a elaboração, onde foi necessário firmar escolhas diante da movediça e multiplicidade de visões que se empenham no esclarecimento das questões abordadas. Porém, creio na relevância desta abordagem para esclarecimento da complexa relação entre cristianismo e secularização, mesmo que este propósito de elucidação não tenha alcançado a profundidade e extensão requerida pela temática. 


\section{2 \\ Secularização: da genealogia às implicações}

Sobre a secularização da nossa era não está em jogo a sua realidade, que se faz notória e aceita por muitos, o que se encontra em jogo é em que consiste este fenômeno. Para possibilitar melhor entendimento, é justo investigar seu processo histórico, sua origem, a demarcação de seus limites e a extensão de seus resultados. Desta forma, será possível interpelar e responder as implicações teológico-pastorais, advindas do processo de secularização, que se apresentam diante do cristianismo.

\section{1 \\ Genealogia, panorama histórico e significado}

Na busca de uma compreensão adequada, será necessário esclarecer em que consiste, o mais especificamente possível, o processo de secularização. Para atingir este objetivo de forma adequada, serão apresentadas as seguintes temáticas: 1) a genealogia da secularização em Giacomo Marramao; 2) panorama histórico por Gibelline; 3) a revelação judaico-cristã e as raízes da secularização; 4) a ética protestante: impulso para abertura secular; 5) Max Weber: entre o desencantamento e a secularização; 6) o secretariado para os não-crentes: uma postura equilibrada.

1. A genealogia da secularização em Giacomo Marramao. Sua abordagem é de extrema importância. Apresenta importantes esclarecimentos sobre a genealogia e o significado do termo A secularização é uma das expressões-chave do debate político, ético e filosófico da contemporaneidade. O percurso será necessário devido ao caráter ubiguitário e dos múltiplos atributos semânticos que o termo foi progressivamente assumindo no desenrolar da história ocidental. ${ }^{10} \mathrm{O}$ que faz Marramao enfatizar que o termo secularização é metafórico em sua natureza, alegando que Santo Mazarino, historiador do mundo clássico, ao analisar a raiz do termo, observara que consistia numa metamorfose. Esclarece que o significado do termo saeculum (século) indica o divórcio que contrapõe Céu

\footnotetext{
${ }^{10}$ Cf. MARRAMAO, Giacomo. Céu e terra: genealogia da secularização. São Paulo: UNESP, 1997, p. 9-10. Marramao indica que Max Weber foi o primeiro a usar o sintagma "processo de secularização", "Säkularisations-prozess" (Cf. Ibid., p. 47).
} 
e Terra, eterno e secular, atemporal e temporal, sagrado e profano, imanente e transcendente.

Ela é a tradução protocristã da natureza 'seminal' e generativa de saeculum (termo que - etimologicamente associado ao verbo sero: 'seminar'. Plantar, ou, em sentido metafórico, 'procriar' - originariamente significa justamente 'geração', implicando por isso a ideia de duração, de um tempo que 'cresce') em polaridade profana contraposta ao eterno, que porta em si todo peso da cisão e do dualismo entre Céu e Terra. ${ }^{11}$

Apresenta a controvérsia de quando e onde o termo secularização teria sido empregado pela primeira vez. Há algumas décadas, entendia-se que teria sido utilizado pela primeira vez na cidade de Münster, durante as negociações voltadas para elaboração do tratado de paz de Westphalia, em 1646, que tinha como objetivo por termo as guerras civis e religiosas que assolavam a Europa. Como resultado destas negociações, o delegado francês Longueville utilizou o termo séculariser, termo até então desconhecido, para se referir à expropriação de bens eclesiásticos em favor dos príncipes ou das igrejas nacionais reformadas. Como, também, era entendido o confisco e a incameração dos bens eclesiásticos durante a Revolução Francesa e na época napoleônica, isto é, num sentido estritamente jurídico. ${ }^{12}$ A interpretação oriunda da utilização do termo, nesta concepção, indicava a submissão do poder espiritual à esfera do poder temporal, tomada historicamente como um vislumbrar do período de transição para o Estado moderno:

Uma visão tal possuía seu poder indubitável de fascínio na conexão, simultaneamente cronológica e simbólica, que instituía entre a gênese do novo lema e nascimento do Estado moderno, cuja soberania "intramundana" (como a teria definido Max Weber, numa expressão destinada a torna-se clássica) vinha por um ponto final no longo e sanguinoso capítulo das guerras civis de religião na Europa. ${ }^{13}$

Porém, esse sentido já consistia num neologismo do termo, constituindo um equívoco etimológico, ainda que possa ser usada neste sentido em nossos dias. $\mathrm{Na}$

\footnotetext{
${ }^{11}$ Ibid., p. 10.

${ }^{12}$ Cf. Ibid., p. 16-17. Alguns léxicos, como o respeitado Wörtrbuch der philosophischen Bergriffe, de Holfmeister, publicado em 1955, sustentavam esta tese.

${ }^{12}$ Cf. Ibid., p. 17. Marramao esclarece que esta convicção - cuja única base filológica limitava-se a uma indicação dada por Johann Gottfried von Maiern em sua edição de 1734 (das) Acta Pacis Westphalia Publica - era errônea.

${ }^{13}$ Ibid., p. 17.
} 
realidade, o termo foi utilizado anteriormente com sentido diferente. Marramao esclarece que "do ponto de vista de uma história conceitual rigorosamente entendida, é preciso constatar que o termo possui um núcleo institucionalmente inequívoco na saecularisatio do Codex Juris Canonic"14. E prossegue:

$\mathrm{Na}$ verdade a referência, a referência a saecularisatio aparece já a partir dos últimos decênios do século XVI nas disputas canônicas francesas (particularmente entre juristas como Jean Papon e Pierre Gégoire), porém com um significado completamente diverso: o de um transitus de regularis a canonicus, ou seja, a passagem de um religioso 'regular' ao estado 'secular', ou de um modo mais geral, como documentam outros estudos, 'de redução à vida laica' de quem recebeu ordens religiosas ou vive segundo regra conventual. ${ }^{15}$

Observando que:

Desde os seus primórdios, o termo secularização mostra-se já marcado por um esquema antitético: o do dualismo de regular e secular que já contém em si, embora apenas virtualmente, a metamorfose moderna dos pares "paulinos" celeste/terreno, contemplativo/ativo, espiritual/mundano. ${ }^{16}$

A extensão semântica ainda pode ser compreendida em termos de dois paradoxos. No primeiro, a secularização se apresenta como a soberania intramundana que se estabelece como um "efeito perverso" e resultado inesperado, induzido pelas pretensões de monopólio do sagrado conforme pretendido pela Igreja. No segundo, implica na burocratização da Igreja e na absorção de características religiosas pelo poder Estatal em suas diretrizes. No entanto, o sentido do termo configura-se, sendo consensualmente aceito, na oposição entre espiritual e secular, sagrado e profano, isto é, mundano. Marramao salienta que a doutrina agostiniana das duas civitates, a Cidade de Deus e a cidade terrena, apresenta a oposição entre espiritual e secular, lançando luz sobre esta antítese que, apesar das metamorfoses, estruturou a cultura ocidental medieval e moderna. No entanto, no século XVIII, o termo passa a ser utilizado desvinculado, de forma específica, do direito canônico e jurídico. Passando à conexão do conceito unitário de tempo histórico, isto é, tempo secular, designando à oposição ou tensão, entre transcendente e imanente. No século XIX, o termo impregnado

\footnotetext{
${ }^{14}$ Ibid., p. 17.

${ }^{15}$ Ibid., p. 17.

${ }^{16}$ Ibid., p. 17-18.
} 
das noções pós-iluministas, ganha o significado de ruptura com o mundo espiritual, recebendo plenamente o sentido do que é mundano. ${ }^{17}$

No decorrer da história ocidental, os termos secularizar e secularização "estiveram relacionados ao lento e tormentoso processo de afirmação de uma jurisdição secular - isto é, laica, estatal - sobre amplos setores da vida social até então sob o comando da Igreja" $" 18$.

Apesar do caráter ubiguitário e a elasticidade dos atributos semânticos, o termo secularização "ascendeu gradualmente ao status de categoria genealógica capaz de sintetizar ou expressar unitariamente o desenvolvimento histórico da sociedade ocidental moderna, a partir de suas raízes (judaico-) cristãs" ${ }^{\text {"19 }}$. Conforme pode ser percebido:

No âmbito ético-político é usualmente utilizada para denotar a perda dos modelos tradicionais de valor e de autoridade, isto é, o fenômeno sociocultural de vasta dimensão que, a partir da Reforma Protestante, consistiu na ruptura do monopólio da interpretação. Já no debate filosófico, ele figura - seja na corrente analítica que na hermenêutica - como sinônimo da progressiva erosão dos fundamentos teológico-metafísicos e da abertura à "contingência": e, portanto, abertura à dimensão da escolha, da responsabilidade e do agir humanos no mundo. ${ }^{20}$

A partir as observações de Weber, a secularização como laicidade seria o destino inexorável do Ocidente, ${ }^{21}$ como "o reconhecimento da realidade do movimento [do progresso] rumo à racionalização do mundo permanece a única e iniludível condição da escolha e do agir do indivíduo moderno"22.

2. Panorama histórico por Gibelline. Apresenta um panorama histórico da postura de diversos estudiosos que se debruçaram sobre o fenômeno. A secularização no sentido cultural possui dois momentos: o de descontinuidade, indicando a emancipação do mundo moderno da tutela do cristianismo; e o momento de continuidade, indicando a contribuição do cristianismo para o mundo moderno e a permanência de impulsos cristãos no mesmo. Devido à complexidade e extensão de suas implicações, o tema da secularização deve ser posto numa

\footnotetext{
${ }^{17}$ Cf. Ibid., p. 22-23

${ }^{18}$ Ibid., p. 19.

${ }^{19}$ Ibid., p. 15

${ }^{20}$ Ibid., p. 10.

${ }^{21}$ Cf. Ibid., p. 50.

${ }^{22}$ Ibid., p. 34.
} 
questão global do lugar da fé cristã, do cristianismo e da Igreja no mundo moderno. ${ }^{23}$

Gogarten $^{24}$ observa três soluções possíveis diante deste fenômeno: a) a recusa da secularização, por poder decompor e destruir a fé cristã, posição que ele vê na crítica de Kierkegaard ao mundo moderno; b) a negação do cristianismo, por não suportar a autonomia do indivíduo moderno que se torna senhor do mundo e de si mesmo, posição que ele vê na crítica de Nietzsche; c) a busca de uma abordagem diferenciada entre fé cristã e secularização, caminho seguido por Gogarten. Nesta abordagem, afirma que a secularização fundamenta-se na essência da fé cristã, sendo consequência legítima da mesma, e identifica com o termo secularismo uma degeneração da secularização. ${ }^{25}$

Em Gogarten, a fé cristã justifica o ser humano, seculariza o mundo, que é entregue à autonomia e responsabilidade humana. $\mathrm{O}$ mundo não é divino, mas criado por Deus. O mundo é mundo, o mundo é mundano. Esta mesma fé realizou a mundanização do mundo, isto é, a fé cristã secularizou o mundo. Logo, o ser humano em sua autonomia está longe da veneração religiosa do mundo, deixando de ser heterônomo para ser autônomo. O mundo mítico se torna mundo histórico pelo processo de historicização dos seres humanos e do mundo. Mesmo sendo pós-bultmanniano na questão do Jesus histórico, Gogarten aceita, relaciona e aplica o programa de demitização de Bultmann à mensagem neotestamentária, alegando ser a demitização a hermenêutica mais apropriada para compreensão neotestamentária numa perspectiva de historicidade. Relaciona o fenômeno da secularização a dois tipos de ateísmo: a) o ateísmo que recusa a veneração religiosa do mundo e da religião, sem se opor à fé cristã; b) o teísmo que recusa também a fé cristã, sendo fruto do secularismo, ou seja, de uma secularização

\footnotetext{
${ }^{23}$ GIBELLINI, Rosino. A teologia do século XX. 2. ed. São Paulo: Loyola, 2002, p. 123.

${ }^{24}$ Considerado o primeiro a tentar legitimar o fenômeno da secularização no âmbito do Cristianismo refletindo do ponto de vista puramente teológico, pondo-o como tema da teologia,culminando na obra: GOGARTEN, Friedrich. Verhängnis und Hoffnung der Neuzit. Die Säkularisierung als theologisches Problem. Muenchem/Hamburg: Siebenstern Tascchenbuch Verlag, 1966. Publicada primeiramente em 1953. O movimento da teologia dialética, a que pertencia Gogarten, já descortinava algumas intuições fundamentas que seriam retomadas, principalmente, por ele em suas pesquisas para valorizar a secularização em nome da fé bíblica Gogarten diferenciava secularização de secularismo, sendo, este último, uma forma anárquica da secularização, uma espécie de sucedâneo da religião, uma forma pejorativa. Ainda hoje o termo secularismo é utilizado por muitos neste sentido, e por outros como expressão quase sinônima de ateísmo.

${ }^{25}$ Cf. GIBELLINE, Rosino, op. cit., p. 123; 130.
} 
incompleta. Alega que a secularização não é alheia nem contraposta à fé cristã, mas tem início com esta fé. Logo, a secularização é um fenômeno pós-cristão. No entanto, a esperança é que a secularização não se degenere em secularismo e que a Igreja não tente cristianizar ou clericalizar o mundo. ${ }^{26}$

Gibellini salienta que a tese de Gogarten, apesar de referencial no debate sobre a secularização nos anos 60, está longe de ser universalmente partilhada, como exemplo, cita a oposição do escritor italiano Romano Guardini e do filósofo alemão Hans Blumenberg. Estas posições divergentes podem ser sintetizadas da forma que segue:

O mapa das interpretações parece completo: ilegitimidade da secularização como processo histórico anticristão (Guardini); no polo oposto, legitimidade da secularização como processo histórico anticristão (Blumenberg); legitimidade cristã da secularização como processo histórico posto em ato pela fé cristã, mas, ao mesmo tempo, ilegitimidade do secularismo como degeneração da secularização (Gogarten). A primeira interpretação e a segunda estão de acordo ao considerar a secularização um fenômeno anticristão, mas o teólogo deduz daí sua ilegitimidade, ao passo que o filósofo reivindica sua legitimidade como ruptura com a Idade Média. $^{27}$

A posição de Gogarten parece mais diversificada por introduzir uma reflexão crítica sobre a secularização, avaliando suas positividades e ambiguidades, sua legitimidade cristã e seus desvios como secularismo, sem observar este fenômeno apenas como processo de descristianização. No entanto, Gogarten não fala em teologia da secularização em sua obra, apenas indica com o subtítulo: secularização como tema da teologia. Porém, com a difusão do debate sobre a secularização nos anos 60 , o termo "teologia da secularização" passa a ser amplamente utilizado. ${ }^{28}$

$\mathrm{Na}$ esteira de reinterpretar a fé para atual sociedade moderna, secular e científica, o bispo anglicano John A.T Robinson publica, em 1963 o texto Honest to God, desencadeando um violento debate. Propunha uma audaciosa síntese dos programas da demitização de Bultmann, do conceito de dimensão e profundidade de Tillich e do projeto de cristianismo a-religioso de Bonhoeffer. Gibellini salienta que Edward Schillebeeckx conceitua o texto de Robinson como uma

\footnotetext{
${ }^{26}$ Cf. Ibid., p. 130-134.

${ }^{27}$ Ibid., p. 137. Apesar das teses de Guardini poderem ser resumidas na expressão "ilegitimidade da secularização", o mesmo não usa o termo secularização em seus escritos (Cf. Ibid., p. 136).

${ }^{28}$ Cf. Ibid., p. 137.
} 
análise lúcida, com apresentações concretas dos problemas teológicos e pastorais da reinterpretação da fé no contexto da secularização. ${ }^{29}$

Em novembro de 1963, o teólogo episcopaliano Paul van Buren publica " $O$ significado secular do evangelho", se perguntando, inspirado em Bonhoeffer: como um cristão secular pode compreender o evangelho de maneira secular? Buscando a resposta faz uma redução do discurso teológico ao cristológico, para em seguida transcrever a confissão cristológica em termos puramente históricos e éticos. Para Gibelline, esta abordagem analítico-secular dos registros neotestamentários não permite afirmar o fato da ressurreição, levando a concluir de forma redutiva que a mensagem do Evangelho significa que a liberdade de Jesus contagiou e se tornou a liberdade dos discípulos. Esta conclusão derivou-se da compreensão de que não é Deus que está morto, mas a palavra de Deus, como qualquer outra palavra que aponta para o transcendente. Posteriormente, Buren abandona esta tese, reconhecendo que a palavra pode articular a linguagem religiosa. Abandona também a teologia da secularização, retornando a compreensão de uma transcendência radical que interpela o ser humano exigindo resposta, onde a teologia é vista a serviço da palavra de Deus na situação humana, que iluminada pela transcendência radical conscientiza-se de seu compromisso na concretude da história. ${ }^{30}$

A secularização retorna ao cenário com o teólogo Harvey $\operatorname{Cox}^{31}$ com o livro $A$ cidade secular, 1965, onde o mundo é visto como tarefa e responsabilidade humana e a secularização designa a emancipação humana, que acontece e se enfatiza dentro do contexto da urbanização. Cox compartilha, semelhante a Gogarten, a ideia de que a secularidade é consequência histórica da fé bíblica e com a distinção entre secularização e secularismo. No entanto, se afasta de Gogarten, ligando secularização à urbanização, onde este ambiente é dominado pela diversidade e desintegração das sociedades tradicionais. Com o intento de elaborar uma "teologia da mudança social" aceita com otimismo as transformações sociais em andamento na sociedade na qual a Igreja terá sua

\footnotetext{
${ }^{29}$ Cf. Ibid., p. 137-138.

${ }^{30}$ Cf. Ibid., p. 138-139.

${ }^{31}$ Um dos primeiros a buscar oferecer uma interpretação sociológica da secularização por meio de digressões teológicas. Retomando a ideia de Gogarten tanto nas raízes judaico-cristãs da secularização, quanto na diferenciação entre secularização e secularismo. Sendo o secularismo uma visão fechada de mundo com função semelhante a religião. Uma breve análise de Cox, apresentando coerência e incoerências se encontram em: BOLAN, Valmor, op. cit., p.18-21.
} 
missão, o que lhe renderá muitas críticas. Após vinte anos, submete $A$ cidade secular à revisão crítica e integração na obra A religião na cidade secular, 1984, reconhecendo que não houve o declínio esperado do religioso e do sagrado, mas sim o despertar destas formas. No entanto, acredita que a mensagem de 1965 não se tornou antiquada.

Gibelline acrescenta que a crítica contestou o desaparecimento da religião em Cox, e também observou o erro de Bonhoeffer sobre o advento de uma era pós-religiosa. Cox passou a se dedicar à emergência do religioso na América do Norte até as comunidades de base na América Latina, identificando nestes contextos os vetores religiosos capazes de renovação e futuro, além das perspectivas da libertação e da solidariedade no contexto latino americano. Acreditando que será a partir da base e da periferia latina que virá a corrente profética para o futuro da religião. Posteriormente, em Cox é superada a teologia da secularização por um cristianismo político e militante, na esteira da teologia política europeia e da libertação, unificando mística e política. ${ }^{32}$

No debate sobre a secularização, a senda católica não registrou a radicalização da senda protestante, principalmente a americana. Karl Rahner enfatizou a necessidade de conscientização para considerar superada a época teocrática da cristandade. A Igreja não deve buscar instaurar uma teocracia, mas reconhecer que o cristianismo tradicional e hereditário passa a ser uma questão de decisão pessoal. Neste novo contexto, a Igreja se encontra em diáspora, no entanto, esta condição pode ser a legitimidade da presença universal da mesma. ${ }^{33}$

$\mathrm{Na}$ linha de Rahner se encontra Marie-Dominique Chenu com seu ensaio $O$ fim da era constantiniana, 1961, enfatizando que a missão da Igreja no mundo profano obrigou a mesma a retornar ao seu caráter essencialmente missionário, que acontecerá num contexto de ausência da opulência da Igreja da época da cristandade. $^{34}$

Nas análises de Rahner e Chenu são utilizados os termos "diáspora" e "fim da era constantiniana", respectivamente, e não especificamente secularização. Porém, caminham para o conceito usual do termo. Este será usado,

\footnotetext{
${ }^{32}$ Cf. GIBELLINE, Rosino, op. cit., p. 139-141.

${ }^{33}$ Cf. Ibid., p. 145.

${ }^{34}$ Cf. Ibid., p. 146.
} 
explicitamente, apenas na segunda metade dos anos 60 pela teologia católica, que inicia uma confrontação ao fenômeno. ${ }^{35}$

Em suas considerações sobre a secularização, 1967, Rahner alerta que a Igreja não pode conduzir o mundo de maneira integrista, isto é, o mantendo sobre sua tutela, e apresenta dois motivos cruciais para esta compreensão: em primeiro lugar, a Igreja não recebeu tal incumbência; em segundo lugar, a Igreja não possui instrumental para guiar o mundo em todas as suas esferas e aspectos. No entanto, a Igreja tem uma missão profética e deve também co-determinar o caminho do mundo secular, porém, sem intenção integrista e sem intenção doutrinária. ${ }^{36}$

Enquanto por um lado, Rahner e Chenu abordam o fenômeno da secularização numa postura dialogal, por outro, divergem desta abordagem Jean Daniélou e Von Balthasar. Daniélou atribui legitimidade do projeto constantiniano, que deveria inspirar a Igreja para uma estratégia na atualidade de laicidade que abarca a liberdade religiosa, mesmo reconhecendo que a Igreja não se encontra mais no contexto de um estado confessional. Hans Urs Von Balthasar, em alguns artigos, 1964-1965, contesta que o processo da secularização seja consequência da fé bíblica, não aceitando também que este processo deva ser avaliado positivamente à proporção que ofereça novas possibilidades à fé cristã, afirmando radicalmente que a atitude de avaliar o mundo mundano positivamente, se iguala a golpear a imanência de Deus no mundo e ultrapassar a demitização de Bultmann. ${ }^{37}$

Gibelline descreve Johann Baptista Metz como aquele que representa a corrente mais avançada de uma avaliação positiva do processo de secularização pela senda católica. Em seus artigos, 1961-1967, reunidos na obra Sobre a teologia do mundo, 1968, Metz acolhe e supera a obra de Gogarten. Enquanto, este último, utiliza o termo secularização, Metz utiliza "mundanização do mundo" e "mundanidade do mundo", salientando que esta realidade que "de-mitiza", "desmagiza" e "des-encanta" emerge no processo da construção da Modernidade, sendo originariamente um acontecimento cristão que no ocidente assume a forma da secularização. Enquanto Gogarten formula sua tese utilizando-se da distinção luterana entre lei e Evangelho, Metz fundamenta-se na encarnação, sendo esta a

\footnotetext{
${ }^{35}$ Cf. Ibid., p. 146-147.

${ }^{36}$ Cf. Ibid., p. 147.

${ }^{37}$ Cf. Ibid., p. 147-148.
} 
aceitação definitiva e escatológica do mundo, tornando-o autônomo e campo da atuação responsável dos seres humanos. Metz mantêm a distinção de Gogarten entre secularização e secularismo, reconhecendo as ambiguidades deste processo e salientando que a mundanização do mundo deve ser legítima como força histórica do cristianismo, e não como um processo que implica em impotência ou indiferença do cristianismo diante deste mundo. Logo, não se pode invocar o fim da época moderna que Metz leva em consideração para mover a sua "teologia do mundo", em três eixos: a) cristológico, a aceitação do mundo na encarnação por parte de Deus; b) antropológico, o mundo é um mundo em devir e que confirma a responsabilidade humana; c) político-escatológico, onde a teologia deve desenvolver as dimensões públicas e sociais da mensagem escatológica cristã, tornando-se teologia política. Gibelline lembra que Metz escreve à seus críticos em A teologia política em discussão, 1969, enfatizando que a teologia não deve permanecer na tese abstrata da secularização, mas avançar nos ideais inseridos no conceito de teologia política. Sintetiza, em 1977, a teologia política em $A$ fé, na história e na sociedade, indicando que para evitar equívocos na emissão de juízo entre fé e secularização e entre cristianismo e modernidade, a "tese da secularização" deve ser superada e integrada criticamente numa "teologia política". Neste contexto, Gibelline indica que, para Moltmann, a teologia não pode ser pura teoria, mas deve tornar-se prática, devendo ser necessariamente "teologia política". A teologia política assumiu o ideário da teologia da secularização na linha de Bonhoeffer-Gogarten-Cox, onde fez confluir um novo programa teológico que enfrenta o mundo secular reconhecendo a mundanidade do mundo, que nada mais é do que reconhecer sua historicidade e o primado da práxis sobre o conhecimento. ${ }^{38}$

O panorama histórico permite observar, apesar de existir divergências, alguns olhares que atribuem as raízes da secularização à fé judaico-cristã como, ainda que de forma embrionária, crucial para o desenvolvimento do Ocidente. ${ }^{39}$

3. A revelação judaico-cristã e as raízes da secularização. Em Gogarten, a secularização encontra suas raízes na revelação judaico-cristã. No Gênesis, o

\footnotetext{
${ }^{38}$ Cf. Ibid., p. 148-150.

${ }^{39}$ Algumas análises interessantes sobre este ponto crucial podem ser encontradas em: BRAGUE, Rémi. La Sagesse du Monde. Paris: Fayard, 1999, p. 219-239; traduzido em: A sabedoria do mundo. São Paulo: Instituto Piaget, 2000; OAKLEY. Francis. Kingship. Oxford: Blackwell, 2000, p. $56-57$.
} 
homem já se conscientiza que é colocado entre Deus e o mundo, sendo exorcizadas todas as potências tenebrosas que o paganismo era tentado a ver. Marramao cita a relação entre fé e secularização em Gogarten:

A relação entre secularização e fé mostra-se aqui de tal modo íntima que não pode haver fé sem secularização do crente para com o mundo. Em outros termos: longe de representar um obstáculo ou impedimento à fé, a secularização na verdade representa sua premissa necessária, o seu imprescindível pressuposto. ${ }^{40}$

Cox, na esteira de Gogarten, identifica as raízes da secularização nas narrativas fundantes da fé de Israel como, por exemplo, “o episódio do Sinai quando Deus destrói os ídolos, relativizando os valores humanos e na proibição de atribuir valores absolutos a tudo que for obra humana"41. Após identificar as raízes da secularização no episódio do Sinai, Cox compreende que as mesmas são potencializadas no episódio da encanação do Verbo, sendo o ápice das raízes da secularização encontrada nas palavras de Jesus: "dai (devolvei) a César o que é de César e a Deus o que é de Deus" ${ }^{\text {42 }}$. Cox prossegue:

Em Jesus, Deus não esmaga a humanidade e seu mundo; pela união hipostática, Ele provoca a plena libertação da humanidade e lhe dá sua autonomia: Jesus não é puro instrumento passivo da divindade. É toda a humanidade e seu mundo que são assumidos por Jesus. Isto seria a libertação do mundo, seu acesso à sua especificidade (a mundaneidade e a profanidade) e à sua autenticidade. ${ }^{43}$

Coadunado com este raciocínio, Thils afirma que:

A concepção hebraica da criação assinala uma saída do círculo fechado da história subjugada à cosmogonia, a sociedade à natureza e o tempo ao espaço; tanto Deus como o ser humano era parte da natureza. E essa concepção estabelece a separação entre natureza e Deus, enquanto a criação e o Criador, tendo o dogma da criação uma importância considerável, para a significação do mundo criado, o que leva alguns a considerar o início da história da salvação com a criação. ${ }^{44}$

Para Berger, o protestantismo foi decisivo historicamente para o fenômeno da secularização, qualquer que tenha sido a importância de outros fatores. No entanto, também concorda que as raízes secularizadoras do mundo podem ser encontradas no Antigo Testamento. A formulação da fé judaica configura-se como

\footnotetext{
${ }^{40}$ MARRAMAO, Giacomo, op. cit., p. 71.

${ }^{41}$ COX, Harvey. A cidade do homem. Rio de Janeiro: Paz e Terra, 1971, p. 32-33.

${ }^{42}$ Cf. Mateus 22, 21.

${ }^{43}$ COX, Harvey, op. cit., p. 32-33.

${ }^{44}$ THILS, Gustave. Cristianismo sem religião? Petrópolis: Vozes, 1969, p. 65-66.
} 
um processo de desencantamento. Por outro lado, alega que a formação social da Igreja cristã influenciou de forma substancial o processo de secularização do mundo ocidental, ainda que de forma involuntária. ${ }^{45}$

Para Vattimo, a secularização não se choca com a mensagem do cristianismo sendo, pelo contrário, um aspecto constitutivo do mesmo. $\mathrm{O}$ episódio da encarnação, kenosis, é entendido pelo autor como um arquétipo de secularização. Isto é, para ele, a raiz da secularização remonta ao cristianismo que se constitui fundamentalmente no esvaziamento da transcendência de Deus. ${ }^{46}$

Porém vale ressaltar, para Taylor, é um equívoco identificar a secularização com desencantamento, presumindo um declínio da fé cristã ou judaica. Este argumento não se sustenta pelo fato do próprio judaísmo e o cristianismo terem promovido, em diferentes épocas, várias modalidades de desencantamento. ${ }^{47}$

4. A ética protestante: impulso para abertura secular. Existe um consenso em situar historicamente a Reforma Protestante como ponto paradigmático para compreensão da secularização. Sendo a obra clássica de Max Weber, A ética protestante e o espírito do capitalismo, uma das primeiras a lançar luz sobre a questão, correlacionando o moderno ethos econômico e a ética racional do protestantismo ascético. $^{48}$

Para Weber, a implantação do ethos do capitalismo moderno para se concretizar necessitaria que o trabalho fosse considerado como um fim em si mesmo, isto é, como vocação. O poderoso aliado para esta realização foi a ética racional do protestantismo. Esta ética racional se inicia com o conceito de Lutero, de vocação, como hoje é entendido. Esta compreensão valorizava a atividade

\footnotetext{
${ }^{45}$ Cf. BERGER, Peter. O dossel sagrado: elementos para uma teoria sociológica da religião. São Paulo: Paulinas, 1985, p. 125; 135. Para Berger, o protestantismo aboliu a maior parte das mediações para o transcendente. Desta forma cortou o cordão umbilical entre o céu e a terra atirando o homem de volta a si mesmo, fato sem precedentes na história. Reduzindo o canal do ser humano com o sagrado, estreitando excessivamente ao canal chamado a palavra de Deus (Cf. Ibid., p. 123-125). Vale enfatizar que a religião possui a dimensão sagrada e a dimensão institucional como aspectos essenciais da mesma. Sem a interação destas duas dimensões não se pode compreender a religião em sua integralidade. Para este aprofundamento: DURKHEIM, Émile. As formas elementares da vida religiosa. São Paulo: Martins Fontes, 2003; ELIADE, Mircea. O sagrado e o profano. São Paulo: Martins Fontes, 1992.

${ }^{46}$ Cf. VATIMMO, Gianni. Depois da cristandade: por um cristianismo não religioso. Rio de Janeiro: Record, 2004, p. 86.

${ }^{47}$ Cf. TAYLOR, Charles. Uma era secular. São Leopoldo: UNISINOS, 2010, p. 498-499. Taylor cita que, a perspectiva de identificação de secularização com desencantamento é apresentada em: GAUCHET, Marcel. Le désenchantement du monde. Paris: Gallimard,1985.

${ }^{48}$ Cf. WEBER, Max. A ética protestante e o espírito do capitalismo. São Paulo: Pioneira, 1999, p. 12.
} 
secular como cumprimento do dever no mais alto grau da atividade moral do indivíduo, atribuindo pela primeira vez um significado religioso ao trabalho secular cotidiano. Sendo esta nova ideia o dogma central de todos os ramos do protestantismo. Logo, viver de forma aceitável a Deus não mais se constituiria na ascese monástica, mas no cumprimento das tarefas seculares cotidianas. No entanto esta concepção em Lutero, inicialmente era tida como neutra, na esteira tomista. Mesmo sujeita as múltiplas interpretações e em contraste com a concepção tradicionalista católica, aumentou a ênfase moral e o prêmio religioso para as atividades seculares e profissionais. Pelo fato desta concepção em Lutero ter permanecido tradicionalista de caráter providencialista não causou impacto no ethos econômico capitalista. ${ }^{49}$

Este impacto no ethos econômico aconteceria com Calvino, que estendeu e solidificou o apego ao mundo e a valorização da vida secular como dever, sendo seguido pelas correntes do puritanismo. Porém, especificamente, foi o cerne do comportamento do ethos religioso que proporcionou o desenvolvimento do moderno capitalismo. Este ethos concentrava-se na força das sanções psicológicas que, originadas da crença religiosa, orientava e prendia o indivíduo. ${ }^{50}$

A doutrina da predestinação de Calvino completa a eliminação da concepção da salvação por meio da Igreja e dos Sacramentos, que se apresentavam como uma espécie de magia. Desta forma, absoluta e decididamente, fica estabelecida a diferença entre calvinismo e catolicismo. No entanto para Weber, esse processo de eliminação da magia ${ }^{51}$ faz parte de um progresso que possui raízes anteriores a modernidade:

\footnotetext{
${ }^{49}$ Cf. Ibid., p. 40-53; 58.

${ }^{50}$ Cf. Ibid., p. 67. Para Weber, a Reforma não implicou na eliminação do controle da Igreja na vida cotidiana, mas sim na substituição por outra forma de controle, isto é, o Calvinismo que "seria, por sua vez, a forma mais insuportável de controle eclesiástico do indivíduo que até então se pode existir" (Ibid., p. 20).

${ }^{51}$ Recorrendo a Max Weber, por magia o puritanismo entendia todo conceito e prática religiosa que poderiam subtender como meios mágicos de salvação, eclipsando ou destronando os decretos divinos. Meios que eram assemelhados a superstição (Cf. WEBER, Max, op. cit., p. 72). E também, recorrendo à Taylor, entende-se por magia: noção que o mundo é permeado por forças sobrenaturais que interferem rotineiramente para o bem ou para o mal em todas as esferas da vida, isto é, o mundo dos espíritos, dos demônios e das forças morais. Onde seres animados e inanimados poderiam absorver tais poderes e transferi-lo a outrem. Onde a religião e seus espíritos estavam por toda parte. $\mathrm{O}$ mundo das bruxas, das peregrinações e dos amuletos. $\mathrm{O}$ mundo da magia branca e da magia negra. O mundo onde as mentes humanas absorviam todas estas concepções como realidades (Cf. TAYLOR, Charles, op. cit., p. 42-115).
} 
Aquele grande progresso histórico-religioso de eliminação da magia do mundo, que começara com os velhos profetas hebreus e conjuntamente com o pensamento científico helenístico, repudiou todos os meios mágicos de salvação como superstição e pecado, chega aqui à sua conclusão lógica. O puritanismo genuíno rejeitava até todos os sinais de cerimônia religiosa na sepultura e enterrava seus entes mais próximos e mais queridos sem música ou ritual, a fim de que nenhuma superstição, nenhuma crença nos efeitos de forças de salvação mágica ou sacramentais, pudesse ser estabelecida. ${ }^{52}$

Processo denominado como Entzauberung der Welt $^{53}$ desenvolvido em outros ensaios na obra Wirtschaftsethik der Weltreligionen:

Já a posição peculiar da velha ética hebraica em comparação com as éticas, a ela intimamente relacionadas, do Egito e da Babilônia, e seu desenvolvimento depois da época dos profetas repousou, como se verá nos ensaios acima citado, inteiramente neste fato fundamental: a rejeição da magia sacramental como uma via de salvação. ${ }^{54}$

A eliminação da magia associada à doutrina da predestinação, combinada com rígidas doutrinas de afirmação da transcendência de Deus e da corrupção da matéria, produziu uma enorme solidão interna no indivíduo. No puritanismo, o desdobramento de todas estas características implicava na rejeição da sensualidade, das emoções, da cultura e qualquer indício de religiosidade subjetiva. Com esta concepção, quase desaparece a confisssão auditiva nestes grupos, por possíveis más intepretações sacramentais, provocando o deslocamento da carga emocional que era descarregada na confissão auditiva para o estímulo psicológico em direção a uma atitude ética específica, proporcionando transformações e abertura necessária para a implantação e estabelecimento da secularização da sociedade. Mudanças que aboliram a descarga periódica do senso emocional do pecado. ${ }^{55}$

A partir destas transformações o mundo passa a ser compreendido como único e exclusivamente lugar para glorificação de Deus. Sendo Deus entendido

\footnotetext{
${ }^{52}$ Ibid., p. 72.

${ }^{53} \mathrm{Na}$ edição usada nesta dissertação, a expressão "eliminação da magia do mundo" é a tradução do termo Entzauberung der Welt. Traduções indicadas para melhor exprimir a ideia de Weber seriam: "desencantamento do mundo"; "desmagização do mundo" e "desmagificação do mundo". Para maiores esclarecimento sobre o termo, ver: PIERUCCI, Antônio Flávio. O desencantamento do mundo: todos os passos de um conceito. São Paulo, Editora 34, 2003. Sobre o "desencantamento do mundo", Vergote salienta que, mesmo Weber sendo agnóstico conseguiu captar com o termo "que a vida perdeu seu chame, quase no sentido do sortilégio poético e religioso que seduz o espírito e o coração", em: VERGOTE, Antoine. Modernidade e cristianismo: interrogações e críticas recíprocas. São Paulo: Loyola, 2002, p. 116.

${ }^{54}$ WEBER, Max, op. cit., p. 167, nota 20.

${ }^{55}$ Cf. Ibid., p. $72-74$.
} 
como requerendo ações e vida social organizada, trabalho especializado em vocações, com a finalidade de amar ao próximo. As atividades seculares se tornam impessoais e promotoras da glória de Deus. As fontes de caráter utilitário da ética calvinista e sua concepção de vocação fez emergir um conflito entre ética e indivíduo, porém tal dilema inexistia para o calvinismo. ${ }^{56}$

Um fator foi crucial para empurrar, com muito vigor, este sistema ético, no mínimo ambíguo, para o mundo secular como elemento do desenvolvimento econômico: a existência de um critério infalível para reconhecimento da eleição. Este critério baseava-se na condição social abençoada por intensa atividade profissional, esta atividade, por sua vez, afugentava a dúvida e certificava da graça, promovendo autoconfiança na própria salvação como eleito de Deus. ${ }^{57}$ Weber nos diz:

Em vez dos humildes pecadores, a quem Lutero prometia a graça se a Deus se confiassem em fé penitente, foram produzidos estes santos autoconfiantes, que podemos redescobrir nos rijos mercados puritanos da era heroica do capitalismo, e, em exemplos isolados, até o presente. ${ }^{58}$

Em suma, o ascetismo cristão que fugia do mundo, agora adentra a secularidade no mercado da vida, penetrando no cotidiano com meticulosidade e na tentativa de moldá-lo racionalmente. Como resultado observa-se os seguintes aspectos:

Mas, o que era ainda mais importante: a avaliação religiosa do infatigável, constante e sistemático labor vocacional secular, como o mais alto instrumento de ascese, e, ao mesmo tempo, como o mais seguro meio de preservação da redenção da fé e do homem, deve ter sido presumivelmente a mais poderosa alavanca da expressão dessa concepção de vida, que aqui apontamos como "espírito" do capitalismo (...). Combinando esta restrição do consumo com essa liberação da busca de riqueza, é óbvio o resultado que daí decorre: a acumulação capitalista através da compulsão ascética de poupança. ${ }^{59}$

Weber descreve que a prática vocacional ascética não é novidade do protestantismo. Porém, o puritano procurou profissionalizar-se e todos tiveram que segui-lo. Com a ascese intramundana foram produzidas condições de grandes

\footnotetext{
${ }^{56}$ Cf. Ibid., p. 74-76.

${ }^{57}$ Cf. Ibid., p. 76-77.

${ }^{58}$ Ibid., p. 77.

${ }^{59}$ Ibid., p. 123-124.
} 
pressões sobre o estilo de vida dos trabalhadores, onde o destino deste caminho se transformará numa prisão de ferro ${ }^{60}$.

No entanto, o capitalismo vencedor com base mecânica não necessita mais do abrigo religioso, agora seu caráter é estritamente secular. Para Weber ninguém sabe como será viver nesta prisão no futuro. Porém, poderá surgir uma petrificação mecanizada ávida por autojustificação:

Neste caso, os 'últimos homens' desse desenvolvimento cultural poderiam ser designados como 'especialistas sem espírito, sensualistas sem coração, nulidades que imaginam ter atingido um nível de civilização nunca antes alcançado' ${ }^{61}$

E assim, "o resultado geral da forma moderna de racionalizar totalmente a concepção do mundo e do modo de vida, teórica e praticamente de forma intencional, foi desviar a religião para o mundo irracional" ${ }^{, 62}$.

Sobre a racionalização apresentada por Weber e sua relação com a secularização, Mariz esclarece:

Embora não se possa identificar racionalização com secularização, pode-se dizer que o enfraquecimento da religião na modernidade foi uma das consequências da racionalização. Segundo Weber, a racionalização teria sido responsável pela diferenciação das esferas sociais, que é característica da modernidade. A religião passa a ser uma entre outras esferas sociais, perde o papel de encompassador que tinha na sociedade tradicional e se restringe a uma função específica. ${ }^{63}$

Para Moltmann, “a 'desmagização' e a racionalização do mundo e de sua história pela ciência moderna produz a irracionalidade, sem sentido, de 'relações' independentes e autônomas, que agora dominam o comportamento humano"64. A racionalização "desmagizou" o mundo, enquanto a secularização o ateizou. ${ }^{65}$

Mesmo estando ao lado da ciência, sem os valores do positivismo, mesmo não propondo o fim da religião, Weber apresenta uma concepção não imparcial da

\footnotetext{
${ }^{60}$ Ou gaiola de ferro em outras traduções.

${ }^{61}$ Ibid., p. 131.

${ }^{62}$ WEBER, Max. Rejeições religiosas do mundo e suas direções. In: Id., Ensaios de Sociologia. Rio de Janeiro: Zahar Editores, 1979, p. 324.

${ }^{63}$ MARIZ, Cecília Loreto. Mundo moderno, ciência e secularização. In: Id., ; FALCÃO, Eliane Brígida Morais (Orgs.). Fazer ciência, pensar a cultura: estudos sobre as relações entre ciência e religião. Rio de Janeiro: UFRJ, 2006, p. 116.

${ }^{64}$ MOLTMANN, Jürgen. Teologia da esperança: estudos sobre os fundamentos e as consequências de uma escatologia cristã. São Paulo: Editora Teológica, 2003, p. 282.

${ }^{65}$ Cf. Ibid., p. 368.
} 
religião, ou seja, avalia pelo viés de sua compreensão da sociedade e o lugar do religioso como papel não racional.

5. Max Weber: entre o desencantamento e a secularização. Para Pierucci ${ }^{66}$, é necessário um esclarecimento sobre Weber. Atribuem a ele uma secularização evolucionista e linear que não chegou a termo no Ocidente, tendo o mundo ocidental entrado recentemente num processo de reencantamento. No entanto, Weber não marcou a morte da religião, não havendo nele profecia a se cumprir. Mesmo diante da própria secularização do cristianismo que, culminou na razão técnico-científica e tecnocrático-funcional do Ocidente, Weber era contrário a qualquer previsão fechada, e quaisquer concepções destes gêneros atribuídas a ele pelos atuais críticos da secularização não passam de incoerência e atribuição à revelia.

No entendimento de Pierucci, o mais precioso em Weber é a compreensão de que a racionalização religiosa se desdobra no desencantamento do mundo implicando na racionalização jurídica, que produz o desencantamento da lei, a dessacralização do direito erigindo o moderno Estado laico como domínio da lei, resultando na perda do valor cultural da transcendência religiosa, o que faz Weber compreender que a secularização já ocorreu.

Outro aspecto esclarecedor nos textos de Weber se refere ao termo "desencantamento do mundo", sendo muito mais frequente que o termo "secularização". Com o termo desencantamento Weber expressa o longo processo de racionalização da religiosidade Ocidental judaico-cristã que, alcançando a sua forma eticizada desencanta o mundo e por meio do puritanismo transita até a primazia da ciência moderna.

Desencantamento e secularização não podem ser tomados por sinônimos. Em Weber, ambos os termos possuem significados diferentes, embora sutil. Por um lado, o desencantamento ocorre em relação às sociedades imersas no religioso, por outro, a secularização é uma emancipação em relação à religião configurando uma subtração para a mesma. Logo, o processo de racionalização é mais amplo

\footnotetext{
${ }^{66}$ Todo este tópico foi extraído de: PIERUCCI, Antônio Flávio. Secularização em Max Weber. Da contemporânea serventia de voltarmos a acessar aquele velho sentido. Revista Brasileira de Ciências Sociais, v. 13, n. 37, jun. 1998, p. 43-73. Trabalho apresentado no Seminário internacional Max Weber na UnB, realizado em Brasília de 22 a 27 de setembro de 1997. Utilizado nesta pesquisa em: $<$ http://www.scielo.br/scielo.php?script=sci_arttext\&pid=S010269091998000200003\&lng=pt\&nrm=iso $>$. Acessos em 29 abr. 2012.
} 
que desencantamento do mundo, enquanto este desencantamento tem duração histórica mais longa.

Enquanto o desencantamento é a luta da religião contra a magia, a secularização é a luta da modernidade cultural contra a religião, tendo como consequência o declínio da abrangência que a mesma possuía anteriormente, culminando na sua separação do Estado. Estas duas realidades, sendo assumidas no processo de modernização, possuem efeito negativo sobre a religião e seguem desencantando o mundo e operando a racionalização da dominação política laicizadora.

De acordo com Pierucci, muitos estudiosos embaralham os conceitos e atribuem a Weber o principal propositor da teoria da secularização, ou pelo menos, seu principal representante, não sendo esta atribuição correta.

As poucas aparições nas obras de Weber dos termos Säkularisation, Säkularisierung, säkularisiert e säkularisierend se referem tacitamente ao plano jurídico ou jurídico-político, onde, nesta esfera, pode-se se falar em secularização completa. Esta concepção pode ser atestada nos escritos de Marramao, Joachim Matthes e Hermann Lübbe, que apontam para este contexto, isto é, para uma legitimação do poder secular com consequentemente declínio da legitimação religiosa, como processo de secularização da lei e da normatividade jurídica geral que se configurou na construção do Estado moderno.

Dentro do significado original a secularização é um fenômeno historicamente verificável e sem controvérsia. ${ }^{67}$ Pierucci finaliza: os críticos, da teoria da secularização, deveriam ater-se a estas constatações, para estabelecer um consenso e rigor categorial mínimo, para serem vencidos ou reduzidos os equívocos sobre a temática se há ou não há secularização. Secularização ou póssecularização? Eclipse do sagrado ou eclipse da secularização? Fim da religião ou fim da secularização?

6. O secretariado para os não-crentes: uma postura equilibrada. Uma síntese do que foi apresentado, até o momento, nesta pesquisa, pode ser observada na exposição de Grumelli. Mesmo com a jornada semântica do termo secularização, é possível uma abordagem fenomenológica, entendendo como um processo de afastamento-destacamento, por parte da sociedade e da cultura, da influência das

\footnotetext{
${ }^{67}$ Para maiores informações: MARTELLI, Stefano. A religião na sociedade pós-moderna: entre secularização e dessecularização. São Paulo: Paulinas, 1996.
} 
instituições religiosas e do sagrado, em suas mais diversificadas manifestações ou concretizações. ${ }^{68}$

Devido às primeiras aparições do termo secularização estando ventilada ao sentido jurídico, por muito tempo significou a passagem (volta) de coisas ou pessoas ao século. Fato que fez o termo permanecer durante muito tempo sendo abordado num plano predominantemente fatal e descritivo, sem que lhe fossem atribuídos avaliações positivas ou negativas. As avaliações negativas lhe foram sublinhadas quando o seu significado foi ampliado além da acepção jurídica. Esta ampliação foi compreendida como um progressivo alargamento da concepção da passagem às coisas do mundo, até indicar algo muito menos complexo e característico do mundo moderno. Porém, com a ampliação do significado e pela gravidade dos problemas de fundo, a temática chamou a atenção às possibilidades de avaliações diversificadas, tanto positivas quanto negativas, principalmente a partir do Iluminismo. Grumelli acentua:

Semelhantes avaliações, tão cheias de contraste, acentuaram-se com a difusão do laicismo (e do anticlericalismo) que no decurso da era iluminista fez saudar com ênfase a libertação dos mitos e das imposições metafísicas que o processo de secularização teria realizado no mundo moderno, enquanto por outro lado se falava em descristianização e se sublinhava o conteúdo cristão desse novo modo de conceber a vida individual e social. ${ }^{69}$

Mas, seria o ateísmo o termo inexorável do processo de secularização? Deveria ser associado esse processo, necessariamente, com a difusão do laicismo e do anticlericalismo? Como trilhar um caminho de equilíbrio da relação secularização e cristianismo?

Para Marty, a secularização se apresenta como a aceitação da historicidade do mundo por parte do homem, abstraindo-se da religião, sendo um fato presente em varias esferas da vida em todos os tempos, não necessitando ser associado às revoluções anticristãs e ao ateísmo. A secularização acentuada e acelerada pela civilização moderna é um fenômeno humano como qualquer outro que se choca

\footnotetext{
${ }^{68}$ Cf. GRUMELLI, Antonio. Dimensão sociológica. In: DONDEYNE, MARLÉ, René. Panorama histórico. In: DONDEYNE, Albert; FRIES, Heinrich, et al. Ateísmo e secularização. Caxias do Sul: Paulinas, 1970, p. 37-37. Este livro contém a maior parte das relações apresentadas durante a sessão europeia do secretariado para os não-crentes, realizada em Viena, entre os dias 10 à12 de setembro de 1968. Apesar de ser uma obra de 1970, esta referência é utilizada devido a sua coerência e ainda, hoje, se encontrar contextualizada, sendo muito de suas indicações e intuições desenvolvidas em autores (as) posteriores, até a nossa época.

${ }^{69}$ Ibid., p. 36.
} 
contra diversas formas de tradições religiosas, sendo este choque uma ambiguidade da secularização a ser esclarecida. Podendo diversas sociedades de nossa civilização viver sem referência a Deus. Apresentar a sacralidade a esta sociedade poder ser um objetivo legítimo da fé. No entanto, uma sociedade secularizada não significa estar imersa na ausência do religioso. Quanto mais secularizado o mundo, mais será necessário diálogo entre crentes e não-crentes, pois a soberania de Deus cobre qualquer distinção entre sagrado e profano, não devendo o que foi secularizado ser considerado estranho à fé cristã e nem a Cristo. A secularização não significa por si só descristianização. Destas considerações, emerge a necessidade de encontrar um novo equilíbrio entre sagrado e profano no interior das sociedades. Marty reconhece que a autonomia humana e dos valores humanos não representa detrimento de Deus, não existindo concorrência entre Deus e o homem. No mundo ocidental, em seu processo de secularização, muitos progressos surgiram de contestações das formas tradicionais do cristianismo. E quando esta forma tradicional se identificou com a cultura, caindo esta, parecia cair também aquela ${ }^{70}$. A secularização não suprime a realidade de Deus, apesar de poder dificultar e tornar diversa sua abordagem. ${ }^{71}$

Retornando à Grumelli, a secularização possui seu lado subjetivo em relação às consciências, e o objetivo em relação às estruturais sociais. Levando em conta estes dois fatores, melhor se descobre suas raízes bem como os fatores que influenciam a evolução destas relações, sendo possível perceber também quais destes dois aspectos mais influenciam a sociedade. Na evolução e interação destes dois aspectos emerge um mundo mais racionalizado e pluralista, onde o sagrado é posto em discussão e a secularização configura-se pela autonomia humana, tornando o sagrado apenas um dos aspectos da vida. A tendência é confinar o sacro na esfera individual. No entanto, a secularização e sacralidade podem se combinar em qualquer tipo de sociedade, permitindo qualificar a mesma segundo a preeminência de uma destas esferas. Porém, uma das características desta configuração complexa pode dar-se na difusão do ateísmo, pois mesmo a

\footnotetext{
${ }^{70}$ Garcia nos esclarece a importância de distinguir o que é próprio da fé e o que é próprio das expressões histórico-culturais, em: GARCIA, Alfonso Rubio. A teologia da criação desafia pela visão evolucionista da vida e do cosmo. In: Id.,; AMADO, Joel Portela (Orgs). Fé cristã e pensamento evolucionista: aproximações teológico-pastorais a um tema desafiador. São Paulo Paulinas, 2012, p. 325.

${ }^{71}$ Cf. MARTY, François. Introdução. In: DONDEYNE, Albert; FRIES, Heinrich, et al. op. cit., p. $7-11$.
} 
secularização não implicando por si só em recusa da religiosidade, pode conduzir ao abandono de uma determinada religião onde a adesão psico-religosa é do tipo cultural e não pessoal. Assim, a secularização poderá conduzir indiretamente ao ateísmo, cujo conteúdo ideológico variará em função dos valores e das atitudes sociais que, majoritariamente, influirão no traduzir a separação do sagrado em recusa de Deus. Dentro deste contexto, a secularização quando se investe na euforia de progresso e na saturação da mentalidade cientifica, possui notável peso para difusão do ateísmo. Percebe-se então que, uma sociedade secularizada pode dificultar a difusão da comunicação e a manutenção da mensagem religiosa, criando obstáculos e até mesmo hostilidade à crença. A difusão da sacralidade pode servir de neutralização para os germes do ateísmo que podem estar presentes no processo da secularização. ${ }^{72}$

Por esta complexidade, pode existir um nexo extremamente variado entre secularização e ateísmo gerando implicações não raramente contraditórias. Por isso, Grumelli enfatiza a necessidade em diferenciar duas modalidades de ateísmo $^{73}$. O ateísmo cultural, podendo ser chamado também de sociológico, que seria o abandono daquela religiosidade agregada à cultura, devido ao indiferentismo religioso proporcionado pelo ambiente. Sendo o outro, o ateísmo ideológico, configurando-se enquanto escolha e convicção meditada, podendo ser chamado de interpretativo ou protestário, buscando traduzir em tom de ateísmo os motivos de protestos individuais e sociais. Justamente, por esta vasta possibilidade, propõe a existência da relação tanto de continuidade como de oposição entre secularização e ateísmo. O pluralismo e racionalização não favorecem apenas o ateísmo, mas pode, igualmente, favorecer o amadurecimento religioso, pelo fato do mundo secularizado não só diferenciar-se do ateísmo, como também lhe opor. Desta forma, o processo de secularização pode ser revelador, favorecendo uma tomada de posição religiosa mais consciente, por ser feita dialeticamente, minando tanto a raiz do ateísmo sociológico quanto do ideológico

\footnotetext{
${ }^{72}$ Cf. GRUMELLY, Antônio, op. cit., p. 37-46.

${ }^{73}$ Grumelli destaca que, apesar de não desenvolver a ideia neste texto, que secularização e ateísmo poderiam ser considerados como dois aspectos do processo único de dessacralização. Sendo a secularização um processo mais natural, e o ateísmo patológico. No plano metodológico enfatiza a necessidade de ampliar os estudos a outras religiões e culturas buscando a propensão de cada uma delas à dessacralização, assim como o fator psicológico envolvido. Considerações importantes para poder lançar previsões para a possibilidade de um processo de ressacralização. Também não nega que o ateísmo possa ter ouras fontes (Cf. Ibid., p. 35-49).
} 
baseados em emotividades ou em condicionamentos sociais. E por outro lado, exige uma adesão religiosa responsável, consciente, convicta e interiorizada, contrastando-a com uma religiosidade deficiente. Observa-se, então, que a secularização pode ser efetiva para do indivíduo favorecendo o aumento e o desenvolvimento da autonomia e da personalidade humana. ${ }^{74}$

Para Dondyne, em nosso mundo o processo de dessacralização e de secularização é um acontecimento cultural inevitável, parecendo também irreversível. Representando para humanidade uma situação de fato e uma tarefa que deve ser realizada em comum, para que se possa construir em escala mundial uma sociedade mais adulta, mais verdadeira, mas respeitosa e com coerência no que diz respeito à autonomia das coisas deste mundo. Sendo os seres humanos, essencialmente, fonte e construtores da civilização e da cultura, e o mundo o encontro de crentes e não-crentes, as transformações e concretizações devem seguir em diálogo. ${ }^{75}$

Sobre o ateísmo advindo do processo de secularização, Dondyne constata que tanto o humanismo ateu quanto o despertar religiosos de nossa era, são frutos da preocupação e afirmação dos seres humanos diante das suas responsabilidades ante a história. Tendo esta raiz em comum, crentes e não-crentes podem e devem se entender até certo ponto. Neste contexto, é de extrema importância uma abordagem filosófica para identificar o ponto de origem e o sentido da divergência, que parte da mesma preocupação e afirmação fundamental sobre a natureza humana, tanto pelo teísmo quanto pelo ateísmo. Sendo esta identificação crucial para um diálogo reciprocamente enriquecedor e autêntico. Apesar de nenhuma filosofia ser capaz de explicar porque um crê e outro não, a mesma pode ajudar na compreensão destas duas hermenêuticas. ${ }^{76}$

\section{2 \\ Os paradigmas da sociologia da religião e as condições de crença em Danièle Hevieu-Léger}

Conhecer os paradigmas da sociologia da religião e as condições de crença possibilitará conhecer e entender as complexas e intrincadas relações da religião,

\footnotetext{
${ }^{74}$ Cf. Ibid., p. 46-47.

${ }^{75}$ Cf. Ibid., p. 51-52.

${ }^{76}$ Cf. DONDEYNE, Albert, op. cit., p. 54-55.
} 
das expressões religiosas e do sagrado na atual sociedade secularizada. Para possibilitar este conhecimento serão analisadas e articuladas as seguintes questões: 1) os paradigmas da sociologia da religião; 2) Peter Berger: qual paradigma?; 3) as condições de crença em Hevieu-Léger, onde será analisada: a) o declínio do poder regulador e suas consequências; b) os atuais sujeitos religiosos: o peregrino e o convertido c) a individualização e a subjetivação do crer.

1. Os paradigmas da sociologia da religião. Para Hervieu-Léger, o principal ponto de partida para a real compreensão da religião no mundo consistiu-se na virada epistemológica dos anos 70 , onde a sociologia da religião se viu obrigada a descobrir que a modernidade secular, supostamente a-religiosa e que estava sob o comando da razão técnico-científica, não passava de uma nuvem de crenças. Até então, a orientação acadêmica reduzia a religiosidade a um conjunto de determinações da religião, isto é, fundamentava-se nas premissas clássicas de análise dos fenômenos religiosos herdadas de Marx e Durkheim. A postura prática de muitos pesquisadores da análise da racionalização do social implicava em reconhecer como se deu a expulsão da religião das sociedades modernas. Inserindo em seus trabalhos a coerência de um processo de secularização. A mensuração do declínio das práticas religiosas corroborava para confirmar a única análise possível na avaliação da religião na sociedade moderna. Para legitimação científica de suas verificações eram obrigados, de certo modo, a confirmar o inexorável desaparecimento da religião. ${ }^{77}$

A virada decisiva da epistemologia obrigou uma revisão dos estudos que além de afetar a sociologia da religião, também atingiria a sociologia que se fundamentava no modelo funcionalista dominante.

$\mathrm{O}$ intenso retorno da religião ${ }^{78}$ nas sociedades ocidentais e a mobilização religiosa no terreno social, político e cultural; o avanço das pesquisas empíricas sobre esta realidade religiosa que se impunha, somada à primeira crise petrolífera

\footnotetext{
${ }^{77}$ Cf. HERVIEU-LÉGER, Danièle. O peregrino e o convertido: a religião em movimento. Petrópolis: Vozes, 2008. p. 17; 20.

${ }^{78}$ Para Vattimo, este ressurgimento do religioso relaciona-se ao medo originado pela ameaça de uma catástrofe global, após Segunda Guerra Mundial. Ele enumera os motivos: medo da guerra nuclear e da proliferação descontrolada das armas nucleares; a degradação da ecologia e das possibilidades de manipulação genética. Além destes medos exógenos. Vattimo aponta para o medo da perda de sentido da existência e o tédio diante da cultura consumista. Sendo esse retorno uma reação induzida pela própria modernidade que produz a destrói as raízes da autêntica da existência (Cf. VATIMMO, Gianni, op. cit., p.21).
} 
que obrigou a reavaliação do conceito secular de crescimento e progresso, redirecionava os olhares da sociologia para um novo horizonte:

$\mathrm{Na}$ proliferação das crenças em sociedades que, devido ao fato da velocidade das mudanças em todos os aspectos, são também sociedades submetidas à tensão de uma permanente incerteza. Ao mesmo tempo em que emergia um vivo interesse pelas formas de religiosidade associadas ao individualismo moderno, abria-se o caminho para uma nova leitura das relações entre religião e política e entre as instituições religiosas e o Estado. ${ }^{79}$

Estes fatos levaram a revisão do conceito linear de secularização e a relação entre religião e Modernidade. Passando esta relação a ser observada a partir dos aspectos da dispersão das crenças e das condutas, e pela desregulação institucional da religiosidade, recebendo religião outra consideração:

Deixa de ser considerada pelo prisma exclusivamente do desencantamento racional, passa-se a ter um interesse maior pelo processo de decomposição e de recomposição das crenças que não se relacionam com o âmbito da verificação e da experimentação, mas encontram-se sua razão de ser no fato e darem um sentido à experiência subjetiva dos indivíduos. ${ }^{80}$

A atual paisagem moderna das crenças constitui-se na peculiaridade da construção individual com maleabilidade, fruição, dispersão, empréstimos e reutilizações das grandes tradições religiosas, o que Hervieu-Léger nomeia como "bricolagem" e outras "colagens" de crenças e tradições. Após estas considerações a autora esclarece:

\begin{abstract}
A "secularização" dessas sociedades não se resume unicamente, já sabemos disso, ao encolhimento de uma esfera religiosa diferenciada. Ela se faz notar, igualmente, na disseminação dos fenômenos de crença, que confere uma pertinência imprevista à formula aplicada classicamente às sociedades não-modernas: "a religiosidade está por toda parte". Religiões "a lá carte", religiosidade "flutuante", crenças "relativas", novas elaborações sincréticas: a religiosidade "vagante", de que falava um dia J. Séguy, já situada, em indeterminação específica, no centro de toda reflexão sobre religião nas sociedades modernas. ${ }^{81}$
\end{abstract}

Deixando por um momento Hervieu-Léger, para sintetizar a diferença entre o antigo e o novo paradigma da sociologia da religião, será utilizado o conceito de

\footnotetext{
${ }^{79}$ HERVIEU-LÉGER, Daniele, op. cit., p. 21.

${ }^{80}$ Ibid., p. 22.

${ }^{81}$ Ibid., p. 25.
} 
secularização, a condição da religião e suas instituições em nossa era secular nos postulados do sociólogo da religião Peter Berger.

2. Peter Berger: qual paradigma? Em suas primeiras obras segue a concepção clássica da teoria da secularização:

Por secularização entendemos o processo pelo qual setores da sociedade e da cultura são subtraídos à dominação das instituições e símbolos religiosos. Quando falamos sobre a história ocidental moderna, a secularização manifesta-se na retirada das Igrejas cristãs de áreas que antes estavam sob seu controle e influência. ${ }^{82}$

E como consequência desta subtração do religioso:

Ela afeta a totalidade da vida cultural e da ideação e pode ser observada no declínio dos conteúdos religiosos nas artes, na filosofia, na literatura e, sobretudo, na ascensão da ciência, como uma perspectiva autônoma e inteiramente secular, do mundo. Mais ainda, subentende-se aqui que a secularização também tem um lado subjetivo. Assim como há uma secularização da sociedade e da cultura, também há uma secularização da consciência. ${ }^{83}$

Abrindo o leque de sua abordagem para atual situação da religião, das instituições religiosas e do comportamento das massas diante das mesmas, Berger afirma:

A característica-chave de todas as situações pluralistas, quaisquer que sejam os detalhes de seu pano de fundo histórico, é que os ex-monópolios religiosos não podem mais contar com a submissão das populações. A submissão é voluntária e, assim, por definição, não é segura. Resulta daí que a tradição religiosa, que antigamente podia ser imposta pela autoridade, agora tem que ser colocada no mercado. Ela tem que ser 'vendida' para uma clientela que não está mais obrigada a 'comprar'. Nelas as instituições religiosas tornam-se agências de mercado e as tradições religiosas tornam-se comodidades de consumo. ${ }^{84}$

Porém, na obra publicada em 1999, Berger parece rever as premissas de sua teoria e afirma:

Ainda que a expressão 'teoria da secularização' se refira a trabalhos dos anos 1950 e 60, a ideia central da teoria pode ser encontrada no Iluminismo. A ideia é simples: a modernização leva necessariamente a um declínio da religião, tanto na sociedade como na mentalidade das pessoas. E é justamente essa ideia central que se mostrou estar errada. Com certeza, a modernização teve alguns efeitos secularizantes, em alguns lugares mais do que em outros. Mas ela provocou o

\footnotetext{
${ }^{82}$ BERGER, Peter, op. cit., p. 118.

${ }^{83}$ Ibid., p. 119.

${ }^{84}$ Ibid., p. 149.
} 
surgimento de poderosos movimentos de contra-secularização. Além disso, secularização em nível societal não está necessariamente vinculada à secularização em nível da consciência individual. ${ }^{85}$

O caráter revisionista parece mais notável ainda quando o autor observa:

O mundo de hoje, com algumas exceções (...), é tão ferozmente religioso quanto antes, e até mais em certos lugares. Isso quer dizer que toda a literatura escrita por historiadores e cientistas sociais vagamente chamadas de 'teoria da secularização' está essencialmente equivocada. ${ }^{86}$

A contundência de outra afirmação "parece" inexorável a reavaliação de suas obras:

Não há razão para pensar que o mundo do século XXI será menos religioso do que o mundo atual. Uma minoria de sociólogos da religião tem tentado salvar a velha teoria da secularização pelo que eu chamaria de tese de última trincheira: a modernização seculariza sim, e movimentos como o islâmico e o evangélico representam a última trincheira de defesa da religião e não podem perdurar. ${ }^{87}$

É valiosa a contribuição de Cecília Loreto Mariz sobre esta posterior compreensão, discutindo algumas ideias, especificamente do capítulo introdutório de Berger denominado The Desecularization of the World. A global overview, da obra organizada em The Desecularization of the World. Ressurgent Religion and World Politics.

Para Mariz, Berger está apenas "aparentemente" revendo algumas de suas posições anteriores, se retratando de ter defendido e colaborado com a tese clássica da secularização da sociedade moderna, ao mesmo tempo em que afirma a força da religião no mundo contemporâneo. No texto, Berger declara que a secularização conforme narrada pela corrente clássica nunca teria ocorrido, e que os processos da secularização e dessecularização devem ser vistos em curso e em relação dialética entre modernidade e religião. Apesar de aparentar sugerir a refutação total da teoria da secularização, principalmente por afirmar que a ideia de que vivemos num mundo secular é falsa, e que a teoria clássica está

\footnotetext{
${ }^{85}$ BERGER, Peter L. A dessecularização do mundo: uma visão global. In: Religião e Sociedade, vol. 21, n. 1, 2000, p. 10. O texto original se encontra em: Id., The Desecularization of the World: A global overview. In: Id., (org) The Desecularizaton of the World: Resurgent Religion and World Politics. Grand Rapids MI: Ethic and Politic Policy Center and W. B. Eerdmans Publishing Company, 1999.

${ }^{86}$ Ibid., p. 10

${ }^{87}$ Ibid., p. 18.
} 
essencialmente errada. Mariz enfatiza que, tanto a oposição do autor à secularização, quanto sua postura de retratamento, pode ser relativizada pelo fato destas posições defendidas por Berger não se afastarem tanto assim de seus trabalhos anteriores. ${ }^{88}$

Mariz salienta que Berger reconhece que houve um processo de secularização, no entanto, esta afirmação contradiz a sua dura crítica à teoria principal da secularização. Pois, ao afirmar que o declínio do religioso não foi observado e que o mundo continua furiosamente religioso, qual seria o sentido do uso do termo dessecularização? Uma vez que só deveria ser utilizado onde a secularização realmente ocorrera e posteriormente tivesse sido revertida. Em outras palavras, se Berger afirma não ter havido declínio do religioso, qual o sentido de utilizar o termo dessecularização? Berger atribui essa dessecularização aos intelectuais islâmicos que retomam a fé após um afastamento, à reunificação do Estado e fé no Irã. No entanto, mesmo reconhecendo a força e o retorno do religioso, parece não estar convicto do poder das forças essencialmente religiosas e da dessecularização na contemporaneidade. Recorre chamando atenção a outras dimensões sociais para compreensão do religioso, chegando a apontar que o antisecularismo dos grupos religiosos correspondem à questão de estarem subordinados aos padrões de bem estar e prestígio da secularidade. Nessa compreensão, o motor do processo de dessecularização se encontraria na luta por ascensão social ou privilégios que, uma vez atingidos, flexibilizariam o comportamento religioso. Do resultado desta dialética ascenderiam incertezas e relativização das verdades religiosas, resultando em certo grau de secularização. Nesse caso, a função da religião na sociedade contemporânea seria desempenhar um papel na luta por aspiração ao reconhecimento da sociedade, por parte dos grupos sem privilégios e hierarquicamente subordinados, como na reelaboração de novas identidades no caldeirão de lutas culturais. Berger chama essa condição de Guerra Cultural, que por um lado explica o surto de um processo religioso radical e, por outro, a incapacidade da elite intelectual de perceber o religioso na atualidade. Para Mariz, Berger permanece como nos trabalhos anteriores: fiel ao

\footnotetext{
${ }^{88}$ Cf. MARIZ, Cecília Loreto. Secularização e dessecularização: comentários a um texto de Peter Berger. In: Religião e Sociedade, vol. 21, n. 1, 2000, p. 26-27. Para a autora, o modelo que Berger apresenta no texto já se esboçavam em: BERGER. Peter L; Brigitte; KELLNER, Hansfield. The Homeless Mind: Modernization and Consciousness. Nova Iorque: Vintage Books, 1973.
} 
modelo weberiano de análise, relativizando o poder explicativo de elementos idealistas e subjetivos da própria religião. ${ }^{89}$

O que podemos perceber desta explanação de Mariz? Que o eco da avaliação da religião pela esteira da racionalidade social, no modelo weberiano, ainda se faz presente em nossos dias na principal corrente da teoria da secularização e, consequentemente, não reconhecendo a própria força da religião enquanto fundamentada no transcendente.

3. As condições de crença em Hevieu-Léger. A autora aponta o que há de peculiar em nosso tempo:

O que é especificamente "moderno" não é o fato de os homens ora se aterem ora abandonarem a religião, mas é o fato de que a pretensão que a religião tem de reger a sociedade inteira e governar toda a vida de cada indivíduo foi-se tornando ilegítimo, mesmo aos olhos dos crentes mais convictos e mais fiéis. Nas sociedades modernas, a crença e a participação religiosa são 'assuntos de opção pessoal': são assuntos particulares que dependem da consciência individual e que nenhuma instituição religiosa ou política podem impor a quem quer que seja. ${ }^{90}$

Mas como chegamos até aqui? Pelo processo onde a Modernidade continua a minar a credibilidade de todos os sistemas religiosos, ao mesmo tempo, fazendo surgir novas crenças, demostrando que a secularização não significa proeminentemente o declínio da religião no mundo. ${ }^{91}$ Assim, se apresenta o quadro da nossa era:

É um conjunto dos processos de reconfiguração das crenças que se produzem em uma sociedade onde o motor é a não satisfação das expectativas que suscita, e onde a condição cotidiana é a incerteza ligada à busca interminável de meios e satisfazêlas. $^{92}$

Dentro desse contexto de reconfiguração, a autora salienta o surgimento de diversas expressões religiosas não racionais e socialmente perigosas, o aumento dos que se dizem "sem religião", e certo aumento em crenças ortodoxas e crenças

\footnotetext{
${ }^{89}$ Cf. MARIZ, Cecília Loreto. Secularização e dessecularização, op. cit., p.27-30.

${ }^{90}$ HERVIEU-LÉGER, Danièle, op. cit., p. 34.

${ }^{91}$ Outras posturas: LYOTARD, Jean-François. A condição pós-moderna. Rio de Janeiro: José Olympio, 1998, aponta em sua introdução: "a incredulidade em relação ao metarrelatos (Ibid., p. xvi)"; como "dispositivo metanarrativo de legitimação (Ibid., p. xvi)", tanto do saber e da política, isto é, o fim da aceitação dos pressupostos de orientação da Modernidade clássica. No entanto, é "tão estranha ao desencanto como a positividade cega da legitimação (...) o critério de operatividade é tecnológico; ele não é pertinente para se julgar o verdadeiro e o justo (Ibid., p. xvii)". Por outro, Vattimo enfatiza não a queda das metanarrativas, mas a queda da legitimação das instituições (Cf. VATIMMO, Gianni, op. cit., p. 109).

${ }^{92}$ HERVIEU-LÉGER, Daniele, op. cit., p. 41.
} 
espiritualistas. Emergindo também, um tipo de ecumenismo de valores universais baseado nos direitos humanos, no entanto, sem referencia à transcendência. A proliferação de crenças, na Modernidade, relaciona-se à recomposição do universo de sentidos perdidos, a partir de problemas individuais. ${ }^{93}$

a) $\mathrm{O}$ declínio do poder regulador e suas consequências. Hervieu-Léger aponta a importância das instituições seculares e religiosas para a transmissão das identidades herdadas na história da civilização. Essa transmissão não significa imutabilidade, pois naturalmente existe uma adaptação à realidade atual. Porém, a modernidade engendrou uma crise na transmissão dessas identidades, ocorrendo certa ruptura com o passado, com a tradição que é detentora da memória autorizada. Logo, em qualquer tentativa de transmissão a crise se encontra instalada, sendo um fenômeno presente em todos os setores da sociedade moderna. Dessa complexa situação surge outro fenômeno característico da atualidade, isto é, não havendo terreno propício para transmissão das identidades, o próprio indivíduo constrói sua própria identidade sócio-religiosa a partir de uma imensa variedade de referenciais simbólicos. Não sendo mais herdadas, as identidades religiosas passam a ser analisadas como resultado de uma trajetória de identificação que se realiza ao longo do tempo, porém sempre precária e susceptível a questionamentos. Da mesma forma que segue construindo a própria identidade, constrói também a própria religiosidade que se afasta da tradição anterior. A figura do religioso fundamentado na tradição religiosa tende a diluir-se diante dessa realidade. Devido a essas possibilidades, dentro de uma mesma tradição podem surgir conflitos identitários, onde as instituições foram dispensadas do seu papel de definir, pela transmissão, a identidade herdada. Surgem desse processo as religiões e crenças flutuantes, relativas, sincréticas, vagante, caracterizadas pela mobilidade. ${ }^{94}$ Diante da multiplicidade das dimensões de identificação religiosas, Hervieu-Léger esclarece:

O ponto essencial, neste percurso, é lembrar que, uma vez que se trabalha com trajetórias, nunca se está lidando com identidades substantivadas e estabilizadas: o problema está, precisamente, em munir-se de um instrumental suficientemente flexível para balizar as etapas de um processo que, por definição, não poderia ser enquadrado dentro de uma descrição definitiva. A religiosidade das sociedades

\footnotetext{
${ }^{93}$ Cf. Ibid., p. $45 ; 50 ; 54-56$.

${ }^{94}$ Cf. Ibid., p. $57-80$.
} 
modernas está em movimento: é este movimento que se precisa conseguir identificar. ${ }^{95}$

b) Os atuais sujeitos religiosos: o peregrino e o convertido. A socióloga propõe dois tipos ideais de sujeitos religiosos em nossa época: o peregrino e o convertido. O peregrino é o sujeito emblema de uma modernidade religiosa que incorpora em sua identidade o movimento, a dispersão a partir da mobilidade de pertenças, da fluidez das identificações e da instabilidade dos agrupamentos. Para uma melhor compreensão, Hervieu-Léger contrapõe o peregrino com a figura do praticante. Este último, o praticante regular, adere a uma religiosidade obrigatória, regida pela instituição, fixa, comunitária, territorializada (estável) e repetida (ordinária). Enquanto, por outro lado, a figura do peregrino consiste na prática voluntária, autônoma, variável, individual, móvel e excepcional (extraordinária). ${ }^{96}$

Outro tipo ideal é o convertido, que se enquadra dentro do contexto do final do século XX que marca o enfraquecimento do poder regulador das instituições religiosas. No entanto, de maneira surpreendente, no final daquele século, houve uma retomada das conversões religiosas. Esse fato, que à primeira vista parece paradoxal, é compreensível. A própria desregulação da crença é inseparável da crise das identidades herdadas que acaba por "favorecer a circulação dos crentes em busca de uma identidade religiosa que eles achem mais adequada à sua natureza e da qual eles devem, cada vez mais, imbuir-se"97.

Nessa configuração, a religião tornou-se assunto de escolha pessoal para o convertido que pode ser representado numa figura tríplice: a) a pessoa que muda de religião; b) a que adere pela primeira vez uma tradição religiosa; c) a pessoa reafiliada, representada por aquela que se converte de dentro, isto é, incorpora uma identidade religiosa de forma fervorosa, mas que até então era formal, mínima e conformista. Todos esses processos de conversão estão imersos numa forte intensidade religiosa, onde se cristaliza um processo de individualização e um desejo de reorganizar a vida pessoal, que muitas vezes se refere a uma espécie de

\footnotetext{
${ }^{95}$ Ibid., p. 80.

${ }^{96}$ Cf. Ibid., p. 98. O exemplo para este "tipo ideal", o peregrino, dado pela autora é a comunidade de Taizé (Cf. Ibid., p. 90-97). Esta comunidade permite "transcender emocionalmente a extrema diversidade dos participantes (diversidade cuja manifestação mais imediata é a pluralidade linguística) e enraizar esta diversidade em uma tradição crente comum" (Cf. Ibid., p. 96). A autora salienta que o convertido não caracteriza o individuo religioso desta modernidade religiosa, mas ele é um personagem que perpassa a história das grades religiões. Ele é, de fato, existente antes do convertido (Cf. Ibid., p. 87).

${ }^{97}$ Ibid., p. 107.
} 
protesto contra a desordem do mundo. ${ }^{98}$ A autora descreve a plausibilidade da conversão nas sociedades secularizadas:

No universo secularizado das sociedades modernas, a projeção desta alternativa religiosa na realidade do mundo perdeu o essencial de sua plausibilidade. Desde então, é o próprio fato da conversão que recobre, de um modo individualizado e subjetivo, a utopia trazida pela mensagem religiosa. A religião não pode pretender nem mudar o mundo, nem regular a sociedade, mas ela pode transformar os indivíduos. ${ }^{99}$

O sentimento engendrado dentro da própria Modernidade culminou como o atual sentimento de insegurança, podendo induzir à reativação da identidade confessional e a busca da imersão no sentimento religioso.

c) A individualização e a subjetivação do "crer". A paisagem das crenças na modernidade religiosa é caracterizada por um movimento de individualização e subjetivização das crenças e práticas religiosas, isto é, o indivíduo está no centro, sendo possível visualizar esta realidade na avalanche da espiritualidade denomina da por F. Champion de "nebulosa místico-esotérica", a qual Hervieu-Léger caracteriza como uma religiosidade centrada no indivíduo e em sua realização pessoal, onde a orientação intramundana da salvação devido à concepção monista do mundo rejeita todo dualismo humano/divino, natural/sobrenatural, questionando também a fragmentação dos saberes. ${ }^{100}$

A crença religiosa da modernidade se configura numa crença desvinculada de uma pertença específica, isto é, um "crer sem pertencer". ${ }^{101}$ Essa religiosidade decompõe o vínculo religioso das comunidades religiosas passadas, do presente ou do futuro e impede a recomposição, ocorrendo uma "decomposição sem recomposição”, conforme, mais uma vez, expressão de F. Champion. Mesmo que possa preservar uma forma de religiosidade individual, essa configuração dissolve as formas de comunalização religiosa. ${ }^{102}$

\footnotetext{
${ }^{98}$ Cf. Ibid., p. 108-110; 125; 128.

${ }^{99}$ Ibid., p. 128.

${ }^{100}$ Cf. Ibid., p. 139-156.

${ }^{101}$ Cf. Ibid., p. 156. "Crer sem pertencer": uma expressão de Gracie Davis.

${ }^{102}$ Cf. Ibid., p. 139; 144; 157-158.
} 


\section{3 \\ Charles Taylor: o complexo processo da secularização}

Para encontrar a resposta em que consiste a secularidade em nossas sociedades, Taylor faz uma pergunta crucial: por que era praticamente quase impossível não acreditar em Deus antes da Modernidade, no mundo pré-moderno e, hoje, muitos acham isso não apenas difícil, mas até mesmo inescapável? ${ }^{103} \mathrm{O}$ itinerário para responder esse questionamento constituirá num esclarecimento para compreensão da peculiaridade da nossa era secular. Essa elucidação abordará a seguinte análise histórico-descritiva: 1) o background do mundo pré-moderno; 2) a Reforma: o desencantamento e a transformação do self; 3) a esfera pública: a secularidade radical; 4) a secularização e as pressões cruzadas; 5) a era da mobilização; 6) as três dispensações do local do sagrado.

1. O background do mundo pré-moderno. Taylor menciona três características do mundo pré-moderno que passaram por transformações: a) o mundo natural com seu lugar no cosmo testemunhando o propósito e a ação divina, onde todos os grandes eventos de ordem natural eram vistos como atos de Deus; b) Deus como fundamento da sociedade, estando Deus em toda parte; c) a concepção de que se se vivia num mundo "encantado" dos espíritos, demônios e forças morais. Com esse background a presença de Deus torna-se inegável e garantia do triunfo do bem, ou pelo menos, manteria a distância as forças das trevas. Nesse mundo o homem estava sujeito, em variadas formas, à ação e à influência das forças sobrenaturais. Nesse contexto o ateísmo chegaria perto de ser inconcebível. O desaparecimento deste background seria parte da resposta à questão crucial, mas não se resumindo apenas nisso, isto é, a transformação do mundo pré-moderno para o mundo moderno não se resume apenas à história da subtração, como é defendido pela corrente da tese da secularização. A transição do pré-moderno para o moderno está intrinsecamente relacionada à mudança na compreensão do significado de plenitude ${ }^{104}$. A possibilidade dessa plenitude não mais se relacionava à dádiva de Deus, mas passava a ser possibilitada pela

\footnotetext{
${ }^{103}$ Cf. Ibid., p. 14.

${ }^{104}$ Por plenitude o autor reconhece a capacidade do ser humano se sentir existencialmente realizado. No mundo pré-moderno esta concepção estava agregada à dádiva de Deus, enquanto que no mundo moderno existem outras possibilidades para esta mesma realização, pelo menos até o momento em que esta passa a não ser mais satisfatória (Cf. Ibid., p. 16-28).
} 
chegada do humanismo exclusivo $^{105}$. A ascensão desse humanismo não pode ser explicada pela tese clássica da teoria da secularização, atribuído à explicação naturalista do mundo e à nova ciência mecanicista do século XVII. Realmente, o advento das ciências naturais não ameaçou a concepção de Deus, mas sim o mundo encantado, problematizando as noções de providências particulares, já que diversos fatos tidos como seculares poderiam ser explicados em termos de estruturas religiosas. ${ }^{106}$ Então, como poderia um humanismo exclusivo preencher o espaço do background anterior, do mundo encantado?

2. A Reforma: o desencantamento e a transformação do self . No mundo pré-moderno coexistiam as questões deste mundo temporal e as questões espirituais, sendo as espirituais pertencentes ao tempo superior, tempo de Deus ou eternidade, que se entendia como a forma elevada de existência que receberia o ser humano após a sua morte terrena. Essas duas esferas conviviam em tensão que poderia deflagrar-se em oposição quando os humanos apegavam-se à sua condição secular como derradeira. No entanto, houve uma série de transformações no mundo ocidental que ocasionou um processo de eliminação desta compreensão da existência. Processo esse que Taylor chama de Reforma ${ }^{107}$, que elimina essa dualidade por completo. A Reforma Protestante, com todas as suas peculiaridades, desferiu um ataque frontal a esse dualismo, sendo o impulso fundamental para o desencantamento do mundo pré-moderno. Posteriormente, o calvinismo leva a uma transformação mais radical, assim como as demais ramificações da reforma. ${ }^{108}$

Para Taylor, a ciência, ao ajudar a desencantar o mundo, contribuiu para a chegada do humanismo com o novo sentido dado ao self ${ }^{109}$ e seu lugar no mundo,

\footnotetext{
105 Um humanismo autossuficiente, ou exclusivo, isto é, cujos objetivos finais não podem ser outros a não ser o próprio florescimento humano. Como florescimento humano é entendido o desenvolvimento das potencialidades humanas, que no cristianismo, apesar de não negar o florescimento, porém ele só seria completo em Deus, porém no humanismo exclusivo, esta realização se daria de forma puramente imanente sem referência ao transcendente. $\mathrm{E}$ as formas formulações cristãs que pareciam apontar para o cristianismo como um agente reacionário para este florescimento complicaram mais as coisas (Cf. Ibid., p. 31-37).

${ }^{106}$ Cf. Ibid., p. 41-43.

${ }^{107}$ Taylor enfatiza: Reforma (com "R" maiúsculo), e que este processo se inicia não muito após as reformas (com " $r$ " minúsculo) hildebrandianas do século XI, que se tratava da tentativa de dar ao laicato uma formação plenamente cristã.

${ }^{108}$ Ibid., p. 318-319.

109 O self em Taylor significa a mente com todas as suas peculiaridades, o eu, a própria pessoa. O autor faz uma distinção pormenorizada da diferença entre o self poroso e o protegido (Cf. Ibid., $p$. $50-62)$.
} 
isto é, o self deixa a condição de aberto, poroso e vulnerável ao mundo encantado, e passa à condição de fechado, protegido em relação a este mundo. Além do desencantamento, foi necessário acreditar nos poderes de estruturação moral dos seres humanos. As possíveis modalidades de humanismo anteriores ao contexto moderno não seriam suficientes para esta época moderna, onde já se estruturava uma nova ordem moral que deveria dar forma e estilo ao mundo natural e social, sendo acionado por algum estímulo a beneficiar o ser humano. Esse benefício, isto é, o humanismo, para que se reportasse à tradição religiosa, deveria ser ativista e intervencionista, necessitando produzir algum substituto para a ágape. Esse humanismo não foi dado, precisava ser imaginado, o que não poderia ser realizado da noite para o dia, mas se emergiu de formas cristãs anteriores, chegando até nós numa série de fases ou mudanças. ${ }^{110}$

No entanto, num processo tão complexo e longo, é necessário verificar alguns pontos cruciais. Foi especificamente a tentativa de reorganização da sociedade pela ala radical do protestantismo - o calvinismo - que a energia do período do medo ${ }^{111}$ foi canalizada para reordenar as questões no tempo secular, tanto da igreja como da sociedade, foi liberada colaborando para o surgimento do humanismo, configurando um processo que Taylor nomeia de "grande inversão" do medo. Desta forma, vai se exaurindo o self poroso enquanto o senso de Deus é aumentado. Porém, mesmo agarrado à crença aumenta-se a percepção de que manter a ordem de integração à sociedade pode ser conseguida pelos humanos. Para que esta confiança na capacidade humana se movesse para o humanismo exclusivo, a referência a Deus deveria ser podada em dois pontos: a) a redefinição do conceito de ordem apenas em termos puramente de florescimento humano; b) buscar o florescimento humano passa a não ser uma capacidade dada por Deus, mas meramente humana. Estas transformações fazem da Reforma Protestante o ponto fundamental para o aparecimento do humanismo exclusivo e posteriormente a nossa atual sociedade secular. Transformações que se deram por meio dos desdobramentos de formas intrincadas e relacionadas aos seguintes movimentos: a) as reformas (com r minúsculo); b) a Reforma Protestante; c) a revolução nominalista; d) ascensão da noção de civilidade; e) o neoestoicismo de

\footnotetext{
${ }^{110}$ Cf. Ibid., p. 42-44.

${ }^{111}$ Sobre o período do medo: DELUMEAU, Jean. História do medo no ocidente 1300-1800: uma cidade sitiada. São Paulo : Companhia das Letras, 2009.
} 
Justus Lipsius proporcionando a base ativista do Estado; e) o deísmo que desloca a concepção de Deus e do universo para a impessoalidade. Desdobramentos que fazem emergir o humanismo exclusivo e Taylor indica que não aconteceram de forma direta, mas em zigue-zague, sendo o neoestoicismo o zigue e o deísmo o zague. $^{112}$

$\mathrm{Na}$ sociedade remodelada, tanto na esfera religiosa quanto na pública, o indivíduo ganhou primazia sem precedentes, gerando uma nova forma de autoconhecimento da existência social. Este autoconhecimento Taylor chama de "imaginário social" "113, que estabelecerá a noção de self, isto é, dará identidade ao indivíduo a partir deste novo contexto. Tal mudança estrutural nas mentes individuais e da sociedade é o que Taylor chama de "a grande erradicação" da estrutura da sociedade anterior. A "grande erradicação" provocada pela nova concepção de ordem moral, teve importância crucial na construção no desenvolvimento social do ocidente e do "imaginário social moderno", principalmente referente às novas teorias do Direito Natural, tendo como base a teoria grociana-lockeana. ${ }^{114}$

A transição da fé para um mundo puramente imanente é ironicamente ${ }^{115}$, e em grande parte, fruto da própria devoção da fé em seu novo modo de se relacionar com o mundo. Tais transformações demonstram que o engendramento da secularização no interior da modernidade é de tal complexidade que descarta

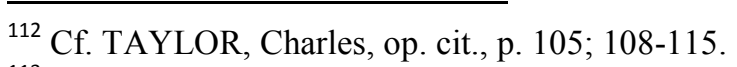

${ }^{113}$ Entende-se como imaginário social, o nosso autoconhecimento, isto é, o modo como nos imaginamos na vida social, e também como entendemos as exigências desta sociedade sobre os nossos comportamentos, mesmo pré-teoricamente. Tal Imaginário tem como instrumentos imagens, histórias lendas etc. Tornando-se possíveis práticas comuns legitimadas. Tomando uma forma ampla do que muitos filósofos contemporâneos chamaram de background. Por sua complexidade indefinida e ilimitada o autor chama de "imaginário" e não "teoria". Porém uma teoria também poder se infiltrar neste imaginário criando novos conhecimentos que não estavam acessíveis anteriormente. Imaginário social e teoria influenciam-se mutuamente. O resultado desta complexidade deu-se na transformação do imaginário das sociedades ocidentais e da nossa era (Ibid., p. 182; 211; 212; 215; 216).

${ }^{114}$ Cf. Ibid., 183. Teorias que chegam até a nossa era sofrendo mudanças e reformulações (Cf. Ibid., p. 198-210).

${ }^{115} \mathrm{O}$ cristianismo fortaleceu a erradicação das perspectivas do mundo encantado, pré-moderno, com as transformações que promoveu. Para Taylor, estas transformações ocorreram sem que fosse evitada certa corrupção do próprio cristianismo, pois elas não levaram a sociedade a uma rede de agápe, mas a uma sociedade disciplinada que tem a norma como primazia em suas relações, mesmo que a intenção tenha sido modificar o mundo de acordo com a espiritualidade cristã. No entanto, as transformações necessárias foram incrementadas de uma forma cada vez mais radical por meio de várias reformas que chegam até nossos dias. E, ironicamente o mundo se transformou em algo bem diferente, pois buscou a imposição do reino de Deus por intermédio da disciplina. De certa forma, Taylor ironicamente alega, pode-se dizer que o mundo venceu (Cf. Ibid., p.195-196).
} 
como sua embaixadora a história da subtração. Mesmo que tais mudanças tenham a ver com as evoluções sociológicas, não se pode descartar a primazia de motivos religiosos em operação. ${ }^{116}$

3. A esfera pública: a secularidade radical. Para Taylor, outro ponto chave para compreender a secularização se refere a ascensão da esfera pública em suas duas faces: a) nesta esfera, a supervisão do poder político deve ser exercida por uma instância fora dele, porém, não Deus, mas, por um discurso racional sobre e para o exercício do poder, e não pelo poder, compreendendo que, "quem faz a lei é a verdade , não a autoridade" ${ }^{\prime 17}$, sendo um movimento sem precedentes na história; b) a sua condição de secularidade radical, não se refere como a remoção de Deus, da religião ou do espiritual do espaço público, mas se refere como algo que colaborou para esta remoção. A nova noção sobre o fundamento da sociedade significa que ela não está fundada no divino, nem em qualquer outra ideia que transcenda a ação comum contemporânea dos seres humanos, e não apenas a transcendência religiosa. ${ }^{118}$

Para Taylor, tal construção conceitual é muito recente na história da humanidade, remetendo esta compreensão ao surgimento da esfera pública no século XVIII. Logo, o termo secular não significa somente "não vinculado à religião", isto é, excluindo a religião. A exclusão é mais ampla, pois a exclusão da esfera religiosa não constitui condição necessária e nem suficiente para constituir a secularidade. A condição secular é aquela que exclui qualquer base divina para ações humanas, porém, nada impede que na condição secular uma sociedade preserve formas religiosas, e estas formas requerem que associações políticas sejam seculares, existindo ainda razões religiosas para se pretender a separação de Igreja e Estado. ${ }^{119}$

Porém, o mundo ocidental presenciou um período de ateísmo, de indiferença à religião e de religiosidade reservada à esfera privada que dava a impressão, num primeiro olhar, que inexoravelmente as expressões religiosas declinariam de tal forma, que muitos pensaram que realmente o seu fim e

\footnotetext{
${ }^{116}$ Cf. Ibid., p. 118-121; 179.

${ }^{117}$ Ibid., p. 233, citação de: HABERMAS, Jürgen. The structural transformation of the public sphere. Cambridge, Mass: MIT Press, 1989, p. 82. Edição portuguesa: Mudança estrutural da esfera pública. 2.ed. Rio de Janeiro: Tempo Brasileiro, 2003.

${ }^{118}$ Cf. Ibid., p. 233-234.

${ }^{119}$ Cf. Ibid., p. 234-238.
} 
desaparecimento era questão de tempo. Podendo apenas, e no máximo, permanecer na vida daqueles que não fazem uso adequado da razão, isto é, a religião e suas expressões foram desviadas para irracionalidade.

No entanto, algo aconteceu. A nossa atual era secular vive, há algumas décadas, um período de efervescência da religião e de múltiplas expressões religiosas. Além das respostas dadas por Hervieu-Léger, qual seria a explicação de Charles Taylor para este fenômeno?

4. A secularização e as pressões cruzadas. As mudanças dos séculos XIX e $\mathrm{XX}$ deram origem ao "efeito nova", isto é, inúmeras alternativas morais e espirituais, incluindo modos de descrença que chegaram até nossos dias. Para esta concretização foi crucial a importância dos seguintes aspectos: a) os desdobramentos das críticas à religião ortodoxa, ao deísmo e ao novo humanismo; b) a expansão da cultura da autenticidade ou do individualismo expressivo que, nascida no período romântico, estimula cada pessoa a procurar o seu próprio caminho, seu próprio prazer e a fazer tudo a seu próprio modo; c) a absorção da cultura da autenticidade às massas em décadas recentes, principalmente, após a Segunda Grande Guerra Mundial, se não mais recente ainda ${ }^{120}$. Porém, o "efeito nova" se desdobra e se intensifica originando uma "supernova espiritual", isto é, um pluralismo crescente do espiritual que se desdobra até nossos dias. ${ }^{121}$

O processo da Modernidade gerou resultados instáveis, que tanto apontavam em direção a um retorno à ortodoxia autoritária, quanto para o ateísmo materialista promovido pelo humanismo exclusivo. Como resultado, o atual debate entre crença e descrença, não se dá apenas sobre estas polaridades, mas também em múltiplas formas dentro destes dois polos, permitindo múltiplas possibilidades de posicionamento, incluindo espaços neutros entre as polaridades. A pessoa que se encontra entre estas polaridades sofre pressões advindas destes dois extremos, do polo da crença e do polo da descrença. Taylor identifica este fenômeno com o nome de "pressões cruzadas". Este "tipo ideal" possibilita

\footnotetext{
${ }^{120}$ Para Taylor, esta era, chamada por ele de "era da autenticidade" (Cf. Ibid., p. 555), não pode ser vista, apenas, como ilusória, hedonista, egoísta e consumista, e também nem isentas de problemas. Houve uma mudança de balizamento moral com novas variedades de opções disponíveis para o comportamento humano, não sendo mais possível um retorno ao passado. E não pode ser ocultado, o que geralmente acontece, é o fato de algumas opções de hoje serem melhores que as antigas. E os ataques frontais e contundentes contra a autenticidade apenas pioram já que não podem fazer o relógio andar para trás (Cf. Ibid., p. 564).

${ }^{121}$ Cf. Ibid., p. 357-358.
} 
compreender a infinidade de expressões pessoais que possam surgir entre os dois polos. $^{122}$

Vale ressaltar, Hervieu-Léger aponta a necessidade de um instrumental que possa ser suficientemente flexível para identificar as multiplicidades de expressões religiosas. O "tipo ideal" que Taylor utiliza como instrumental parece permitir esta verificação.

Para suas discussões acerca do fenômeno religioso e do processo de secularização, Taylor descreve um sentido adequado para se compreender o que se entende por religião, o que ele chama de sentido forte ${ }^{123}$ :

Não só crenças e ações baseadas na existência de 'entidades sobrenaturais' (também conhecidas por Deus), mas também na perspectivas da transformação dos seres humanos que os leva além ou para fora do que é entendido como florescimento humano, inclusive em um contexto de razoável mutualidade ( isto é, onde trabalhamos pelo florescimento mútuo). No caso cristão, isso se refere a nossa participação no amor (agápe) de Deus pelos seres humanos, e por definição é um amor que vai além de qualquer mutualidade possível, um dar-se a si mesmo não amarrado a nenhuma medida de justiça. ${ }^{124}$

Esta crença presume um poder sobre-humano (Deus) que nos chama e capacita a responder a perspectiva de transformação que ele abre. Porém, em nossa era há muitas pessoas que desejam localizar-se numa posição intermediária entre a perspectiva de transformação e a perspectiva de imanência. Esta última tende a ser apoiada por uma concepção materialista. Com esta postura busca-se fugir do materialismo ou da visão estreita do moralismo do benefício mútuo, mas

\footnotetext{
${ }^{122}$ Cf. Ibid., p. 361-381; 383-416; 697-723. Para Taylor, as formas de descrenças emergidas no século XIX, e que ainda são sustentadas hoje, caracteriza a maior idade do ateísmo, com solidez, profundidade e com um complexo de diferenças internas. Taylor fica tentado a dizer que, o cisma entre fé e descrença ocorreu no século XIX, e não realmente no Iluminismo. Contribuindo para isso, e também para aumentar as pressões cruzadas o movimento contra os valores iluministas, isto é, um "contra-Iluminismo imanente", no qual se insere a postura de Nietzsche, sendo este movimento crucial para ampliar o leque das opções de descrença. Com o desenrolar das multiplicidades das posturas de crença e descrença e das pressões cruzadas, emergiu uma raça de seres humanos que conseguiu experienciar o mundo de forma puramente imanente, podendo este fato ser visto como vitória da escuridão, porém uma conquista extraordinária (Cf. Ibid., p.436444). Na última metade do século XX parece que o ocidente entra num novo mundo, onde os vínculos anteriores praticamente desapareceram, isto é, as formas de humanismo e de fé não estão vinculadas ao debate do passado, hoje estão conectadas ao mesmo ideal, todos partidários dos direitos humanos, triunfando assim o ideal moderno (Cf. Ibid., p. 491).

${ }^{123}$ Cf. Ibid., p. 606.

${ }^{124}$ Cf. Ibid., p. 505.
} 
não querendo retornar às fortes demandas da visão da transformação, com suas crenças de grande alcance a respeito do poder de Deus em nossas vidas. ${ }^{125}$

Taylor enfatiza, a secularização centra-se no fato que a Modernidade levou a um declínio da perspectiva da transformação, proposição que os ortodoxos da tese da secularização também concordariam, mesmo sem eleger a centralidade desta perspectiva.

A tese ortodoxa da secularização enumera alguns vetores seculadores como a urbanização e a migração. Porém, Taylor apresenta a sua própria compreensão sobre estes vetores:

Fatores como urbanização, migração etc. contam. Porém, o modo como eles contam não é produzindo uma atrofia na motivação religiosa independente. Pelo contrário, e isso foi e é evidente na criação de novas formas, substituindo aquelas formas arruinadas ou inviabilizadas por esses agentes "secularizadores". O vetor de todo esse desenvolvimento não aponta na direção de algum tipo de morte térmica da fé. ${ }^{126}$

Isso não significa que a religião continua constante, podendo assim refutar esta visão na tese predominante da secularização, pelo contrário, em nossa era:

O cenário presente, despido das formas mais antigas, é diferente e irreconhecível para uma época mais antiga. Ele é marcado por um inaudito pluralismo de pontos de vista, religiosos, irreligiosos e antirreligiosos, no qual o número de posições possíveis parece estar crescendo sem fim. Em consequência, ele é marcado por uma grande dose de fragilização mútua e, por conseguinte, por um movimento entre diferentes pontos de vista. Isso naturalmente depende do meio em que se vive, mas está cada vez mais difícil encontrar um nicho em que fé ou descrença são algo óbvio. E, em consequência disto, a proporção de fé é menor e a descrença maior do que em qualquer outra época passada; e fica ainda mais claro que isso é assim se a religião for definida em termos da perspectiva de transformação. ${ }^{127}$

Após todas estas considerações, a visão de Taylor sobre a secularização é assim descrita:

É que certamente tem havido um 'declínio' da religião. A fé religiosa passou a existir num campo de escolhas que inclui várias formas de objeção e rejeição; a fé cristã existe em um campo em que há também um amplo leque de outras opções espirituais. ${ }^{128}$

\footnotetext{
${ }^{125}$ Cf. Ibid., p. 505-512.

${ }^{126}$ Ibid., p. 512-513.

${ }^{127}$ Ibid., p. 513.

${ }^{128}$ Ibid., p. 513.
} 
Onde essa descrição difere das teorias de secularização predominante, que apontam para o declínio da religião, em nosso caso, a cristã? Já que a descrição concorda com este declinar. Difere na última sentença da citação anterior: a fé cristã se encontra num campo de múltiplas opções. Logo:

A história que nos interessa não é simplesmente uma história de declínio, mas também de uma nova determinação do lugar do sagrado ou espiritual na vida individual e social. Essa nova localização tornou-se uma oportunidade para recomposições da vida espiritual em novas formas, e para novos modos de existência tanto na relação com Deus quanto fora dela. ${ }^{129}$

5. A Era da Mobilização. No itinerário das transformações das sociedades ocidentais, Taylor identifica um período que ele designa como a Era da Mobilização ${ }^{130}$, sendo um processo de nova configuração e formas de sociedade, igreja, associação, alteração do imaginário social e seu senso de legitimação, e definição do que é central na própria vida e na sociedade. ${ }^{131}$

Taylor descreve a Era da Mobilização como o desenrolar de um processo de continuidade e descontinuidade, isto é, de decomposição e recomposição de regimes políticos e religiosos. As sociedades protestantes, baseadas na ordem do benefício mútuo, proporcionava uma cultura onde adesão religiosa só seria legítima sendo voluntária ${ }^{132}$. Desta forma, o imaginário denominacional torna possível uma flexibilidade jamais vista nas sociedades ocidentais, permitindo uma abertura às pluralidades de denominações e a tendência de separar religião do Estado, não se podendo aspirar pelo éthos de uma igreja nacional. ${ }^{133}$

Nas sociedades modernas, dependendo de sua configuração políticoreligiosa, pode existir um declínio da fé e da prática religiosa, desde a retardação até a não ocorrência. Este fenômeno leva ao mal entendido da sociologia ver a religião apenas como função integradora, sendo a fé dependente da modernidade. Porém, para Taylor, distorceria menos compreender a linguagem religiosa como "aquela em que as pessoas consideram significativo codificar sua forte

\footnotetext{
${ }^{129}$ Ibid., p. 513.

${ }^{130}$ Taylor apresenta os limites da Era da Mobilização entre 1800 a 1950, podendo avançar até 1960 (Cf. Ibid., p. 552).

${ }^{131}$ Cf. Ibid., p. 522.

${ }^{132}$ Sendo os metodistas wesleyanos o protótipo desta nova forma de igrejas livres, que explode no final do século XVIII nos EUA, transformando a face da religião norte americana (Cf. Ibid., p. 526-528). Movimentos que por suas perspectivas torna-se uma força anti-hieráquica e parte impulsionadora para democracia (Cf. Ibid., p. 528-530).

${ }^{133}$ Cf. Ibid., p. 526-528; 532.
} 
experiência moral e política, seja de opressão ou de construção exitosa do Estado, em torno de certos princípios morais" ${ }^{\prime 134}$. Observa-se algo crucial para a tese básica do sentido de secularização dado por Taylor: "o padrão da vida religiosa sob a 'secularização' é de desestabilização e recomposição, constituindo um processo que pode ser repetido muitas vezes" ${ }^{\prime 135}$.

6. As três dispensações do local do sagrado. O escopo geral da religião desde o fim da Idade Média configura-se em três fases: o esvaziamento das formas do ancien regime; originando as formas da Era da mobilização; sendo as formas da Era da Mobilização solapadas na segunda metade do século XX. ${ }^{136}$ Estas três fases compreendem o lugar do sagrado na sociedade ocidental em três dispensações. A primeira, designada como paleodurkheimiana:

A minha conexão com o sagrado implicava o meu pertencimento a Igreja, que em princípio era coextensiva com a sociedade, embora de fato talvez ainda se tolerasse alguns que estavam de fora e que ainda eram hereges não submetidos à disciplina (...) se podia e - de fato se fez - demandar que as pessoas fossem forçadas a se integrar, a se vincular legalmente com Deus contra a sua vontade (...). ${ }^{137}$

\section{A dispensação neodurkheimiana:}

Implica um passo importante na direção do indivíduo e do direito de escolher. Adere-se a uma denominação porque parece direito. E, na verdade, agora até parece que não há outra maneira de estar na "igreja", exceto por meio da tal escolha (...). A coerção passou a ser não só errada, mas absurda e, portanto, obscena. ${ }^{138}$

Porém, esta compreensão leva a esta dispensação a um estágio mais avançado, pois o imaginário social do individualismo expressionista absorve uma nova compreensão do lugar do sagrado, onde este passa a não se emoldurar mais pela igreja, pelo Estado ou pela lealdade política, mas sim pela própria moldura do indivíduo. Assim Taylor descreve a dispensação pós-durkheimiana:

A visão expressionista levou isso a um estágio mais avançado. A vida ou prática religiosa, da qual me torno parte, deve ser não só da minha escolha, mas também deve falar a mim, deve fazer sentido em termos do meu desenvolvimento espiritual como eu concebo. Isso nos leva adiante. Entendia-se que a escolha da denominação

\footnotetext{
${ }^{134}$ Ibid., p. 538.

${ }^{135}$ Ibid., p. 540-541.

${ }^{136}$ Cf. Ibid., p. 541.

${ }^{137}$ Ibid., p. 571.

${ }^{138}$ Ibid., p. 571.
} 
deveria ter lugar no interior de um quadro fixo, isto é, o do Credo apostólico, o da fé da "igreja" mais ampla. Dentro dessa moldura de fé, eu escolho a igreja que eu me sinto mais confortável. Porém, se agora o foco passa a recair sobre o meu próprio caminho espiritual, ou seja, sobre que percepções capto nas linguagens sutis que considero significativas, então fica muito difícil manter essa ou qualquer moldura. ${ }^{139}$

Dentro da postura pós-durkheimiana observa-se não só o pluralismo, mas o pluralismo ilimitado, devendo apenas respeitar o caminho espiritual do outro, estabelecendo apenas o princípio do dano, e a recusa de aceitar alguma autoridade externa. Uma forma desta espiritualidade é sintetizada nas seguintes palavras: "aceita somente aquilo que soa verdadeiro ao teu próprio interior"

Em suma, em nossa era secular pós-durkheimiana, a configuração das expressões religiosas pode ser caracterizada pelas seguintes indicações: a) a busca por espiritualidade e não pelo religioso; b) uma busca, mas imediata, direta, espontânea e profunda do sagrado, principalmente pelas pessoas mais jovens; c) a ênfase na inteireza, na individualidade e na subjetividade; d) uma linguagem que invoca harmonia e sentimentos. Sendo estas posturas, uma resposta para vida encerrada no puro imanente, como sendo uma vida vazia destituída de um propósito mais elevado. Para Taylor, nem todas estas formas de espiritualidades devem ser consideradas como trivial ou privatizadas, consideradas como meras extensões do tipo New Age, e como meras extensões do movimento do potencial humano, que não fazem referência à transcendência, onde no máximo se fará referência a uma espécie de força vital concebida em termos imanentes. Mas muitos movimentos e pessoas desejam ir além destas concepções na busca da espiritualidade. $^{141}$

\section{4}

\section{Um olhar panorâmico}

Diante de todas estas considerações, como pode a teoria da secularização possuir tanto espaço, principalmente na Europa? Taylor enfatiza que "a aceitação geral dessa história contribuiu, por seu turno, para um declínio da crença e da

\footnotetext{
${ }^{139}$ Ibid., p. 571.

${ }^{140}$ Ibid., p. 575, nota de rodapé $n^{\circ} 31$. Palavras de Sir George Trevelyan, numa palestra proferida no Festival em prol da Mente, do Corpo e do Espírito. Taylor extrai esta citação de: HEELAS, Paul. The New Age Moviment. Oxford: Blackwell, 1996, p . 21.

${ }^{141}$ Cf. Ibid., p. 571; 575; 593-599.
} 
prática como profecia que se cumpre a si mesma"142. No entanto, ocorreu um declínio na crença e na prática e, além disso, foi perdido o status inquestionável de que gozava a crença em séculos passados, sendo este declínio "o fenômeno maior da secularização" ${ }^{\prime 143}$. Logo, a correta compreensão deste fenômeno, permite entender, consequentemente, o atual mundo secularizado:

Trata-se de um mundo pluralista, no qual muitas formas de crença e descrença se chocam e, em consequência, fragilizam uma às outras. Trata-se de um mundo em que a crença perdeu muitas das matrizes sociais que a faziam parecer "óbvia" e inquestionável. Não todas, é claro; ainda há ambientes em que ela representa a solução "defaut [padrão]": a não ser que você tenha intuições muito fortes em contrário, parecerá conveniente que você prossiga dessa maneira. Também temos, porém, ambientes em que a descrença está muito mais próxima de ser a solução defaut (incluindo parcelas importantes da academia). Assim sendo, por toda parte aumentou a fragilização. ${ }^{144}$

Num olhar panorâmico, pode-se observar que a secularização, apesar do caráter ubiguitário, da elasticidade dos atributos semânticos e não possuir um conceito unívoco pode ser estudado fenomenologicamente.

O grande problema da secularização dá-se quando seus intérpretes colocam a autonomia humana em chave de oposição tanto à religião quanto à transcendência, desenvolvendo uma leitura dualista da realidade.

Uma compreensão equilibrada sobre a secularização e sua relação com a sacralidade, deve perceber que o problema do fenômeno não reside apenas, e nem principalmente, na relação conflituosa entre ciência e religião ou entre fé e razão. O pensamento científico não bane os deuses, e estes não banem a concepção científica e a historicidade do mundo. Tampouco, se deve tratar de pura substituição, isto é, a transferência de uma cosmovisão religiosa para uma cosmovisão científica como necessária para a compreensão do mundo. Igualmente não significa ser a descristianização, o anticlericalismo ou o ateísmo o seu termo inexorável. Não implica, necessariamente, como visto, na eliminação dos fenômenos religiosos, mesmo que seja identificado o declínio da influencia institucional, mas uma reconfiguração da sociedade comparada aos modelos tradicionais pré-modernos.

\footnotetext{
${ }^{142}$ Ibid., p. 622-623.

143 Ibid., p. 624.

${ }^{144}$ Ibid., p. 624-625.
} 
A secularização significa o processo de uma nova configuração na leitura da realidade e um novo sentido na identidade humana, do mundo e, consequentemente, também de Deus. Esta nova configuração leva em conta uma análise tríplice. Eventos e circunstâncias históricas são compreendidos a partir de três processos, todos eles entendidos com secularização em níveis de análise distintos: primeiro, o processo de autonomização das esferas da sociedade em relação à religião, no nível de análise macro; segundo, o processo de pluralização da religião, no nível de análise meso; terceiro, o processo de privatização da religião, no nível micro.

O primeiro desses processos anteriores é analisado considerando-se a autonomização do Estado, da educação e do direito - processos decisivos para configuração da atual sociedade e do Estado de Direito; o segundo é analisado através de um olhar para as transformações das esferas religiosas da sociedade; o terceiro processo é examinado a partir do advento da religião como assunto de esfera privada do indivíduo, no entanto, num contexto de grande mobilização religiosa, pertencimentos múltiplos e variadas composições religiosas individuais.

Logo, a pretensão e presunção da descrença apontando o não-crer como padrão ideal, perdeu a sua plausibilidade, pois a crença existe e configura-se como plausível, ainda que no atual imaginário social exista desconfiança quanto à possibilidade de uma concepção unitária da fé, e a não aceitação da influência institucional sobre a totalidade da vida dos crentes, fato demonstrado pela individualização do crer.

Para que equívocos sejam evitados, é necessário distinguir o que é próprio da fé de suas expressões histórico-culturais, bem como os limites do processo da secularização.

\section{5}

\section{Implicações teológico-pastorais}

Para Urbano Zilles, um dos fatores importantes à mudança em relação à religião foi a grande virada antropocêntrica promovida pela revolução copernicana, que modifica na filosofia moderna a problemática de Deus, que passa a ser tematizada a partir da subjetividade do ser humano e da relação deste com o mundo, e não mais a partir do mundo. O pensamento passa a indagar sobre 
a existência de uma dimensão do ser humano correlata à religião, e se esta dimensão seria algo a priori como um sentimento universal e irracional, ou se a religião seria algo precedente a todos os conteúdos categoriais da mente. O processo de emancipação do ser humano em relação à autoridade e à tradição do período anterior, levando-o por si mesmo a ver, julgar e decidir tornando-o ponto de referência da realidade que é pensada a partir da pessoa e projetada para ela, onde a ciência e a técnica, que supostamente davam o senhorio para a manipulação da realidade e o planejamento racional, resultam num mundo hominizado e secularizado apresentando-se despido dos vestígios de Deus, sendo o cristianismo considerado uma ideologia reacionária. ${ }^{145}$

O processo de secularização trouxe em sua esteira diversas implicações teológico-pastorais ${ }^{146}$, que interpelam o cristianismo em diversas esferas e níveis, tanto institucionais quanto individuais.

\subsection{1 \\ Ciência versus religião: imanência versus transcendência}

O confronto entre ciência e religião, constitui-se num dualismo em chave de oposição que não permite a abertura dialógica entre estas esferas. Configura-se uma oposição entre imanência e transcendência.

1. O ateísmo da ciência evolucionista. A ciência natural evolucionista e seu materialismo apontam à incapacidade dos postulados religiosos e metafísicos para compreender a realidade do mundo. Afirmando que pela supremacia do conhecimento científico e a tecnologia aliada a ele, os únicos postulados plausíveis, deveria ser este conhecimento o responsável pelo quadro interpretativo do universo, e assumir a tutela e a orientação da humanidade rumo ao progresso. Implicando na confirmação da insuficiência e da nulidade da fé em Deus e da religião. Logo, deveriam ser superadas ou se manterem, no máximo, no âmbito privado das mentes irracionais e retrógradas. Este ateísmo enfatiza que na natureza, entendida em termos científicos, não há mistérios, e assim, invalidam a noção de milagre, como intervenção que interrompe a ordem regular da natureza.

\footnotetext{
${ }^{145}$ Cf. ZILLES, Urbano. Filosofia da religião. São Paulo: Paulus, 1991, p. 8-12.

${ }^{146}$ Por implicações teológico-pastorais, entende-se: à interpelação do mundo secularizado tanto à teologia quanto à pastoral cristã.
} 
$\mathrm{Na}$ visão desta ciência evolucionista Deus não seria necessário, nem mesmo concebível $^{147}$.

2. Criação versus evolução: a controvérsia. Diante da especificidade e busca de concretude do método experimental, a fé cristã encontra um obstáculo para falar de Deus. Principalmente quando esta fé é formulada por uma teologia que se encontra presa às formas, demasiadamente, antropomórficas das imagens bíblicas sobre Deus. Na esteira deste debate encontra-se um obstáculo hermenêutico em relação ao jogo de linguagem da fé cristã e a científica. Há urgência de buscar-se a superação deste obstáculo, para que a fé cristã possa constituir-se como relevante para emitir juízo, de uma forma global sobre a existência.

\subsection{2}

Razão versus fé: oposição ser humano versus Deus

O debate entre razão e fé, configura a segunda chave de oposição, configurando-se num agravamento em relação à primeira, isto é, da ciência versus religião. Enquanto a primeira chave de oposição é menos interiorizada e menos reflexiva, a questão razão versus fé intensifica e interioriza a reflexão em nível existencial, culminando no sombrio dualismo em chave de oposição entre o humano e Deus.

A realidade destas oposições, concomitantemente e inter-relacionadas, configura um campo de batalha, um duelo de braço de ferro onde é intensificado o

\footnotetext{
${ }^{147}$ Cf. TAYLOR. Charles, op. cit., p. 643. Na vasta referencias que abordam este temática são esclarecedores as obras: TAYLOR. Charles. Op. cit., onde as referências a estas questões permeiam o seu texto mas concentram-se nas seções "estrutura imanente" (Cf. Ibid., p. 633-695) e "pressões cruzadas" (Cf. Ibid., p. 633-695). Principalmente sobre a questão da dependência dos proponentes da ciência das narrativas dos proponentes da morte de Deus, e a esperança destes da ciência fundamentar suas narrativas. A origem do "ateísmo moderno nasce com a radicalizacão do Iluminismo francês e, depois, com Feuerbach, Marx, Nietzsche e Freud. Tal ateísmo penetrou em todas as camadas sociais e, sob o pretexto de cientificidade ameaça a fé em Deus e a religião e, especificamente, o cristianismo. O homem passa a autodeterminar-se de maneira atéia. A orientacão atéia não ocorre só no comunismo, mas também a ciência e a técnica, como certas correntes filosóficas contemporâneas, são atéias em sua orientação. Assim, hoje, quem quiser viver a fé em Deus terá que confrontar-se também com esse tipo de ateísmo" (ZILLES, Urbano, op. cit., p. 99). Para aprofundamento: ARNOULD, Jacques. A teologia depois de Darwin. São Paulo: Loyola, 2001. SEGUNDO, Juan Luís. Que mundo? Que Homem? Que Deus? Aproximações entre ciência, filosofia e teologia. São Paulo: Paulinas (Coleção Teologia Atual) 1995. RUBIO, Alfonso García. A teologia da criação desafiada pela visão evolucionista da vida e do cosmo. In: RUBIO, Alfonso García; AMADO, Joel Portela. Fé cristã e pensamento evolucionista. São Paulo: Paulinas, 2012, p. 25-28. RUBIO, Alfonso García. A visão científica evolucionista interpela a fé em Deus criador. In: Atualidade Teológica. Ano XV, n. 37, janeiro-abril de 2011, p. 47-64; Id.,. Unidade na Pluralidade: o ser humano a luz da fé e da reflexão cristãs. São Paulo Paulus, 2001. DAWKINS, Richard. Deus: um delírio. São Paulo: Companhia da Letras, 2007. HAUGHT, J. F. Deus após Darwin: uma teologia evolucionista. Rio de Janeiro: José Olympio, 2002.
} 
extremo dualismo que tem como objetivo a ciência desmantelar a religião ${ }^{148}$, a razão desmantelar a fé para o ser humano suplantar a crença em Deus.

1. Feuerbach e os mestres da suspeita. Os principais proponentes desta segunda chave de oposição são representados por Feuerbach e os mestres da suspeita: Karl Marx, Nietzsche e Freud. Estes representantes "esperam com recurso à natureza e à ciência e com o desmascaramento da alienação religiosa, obter a transformação da consciência." 149 Posição viva e presente na atualidade, questionando a fé cristã e entendendo a superação da mesma como progresso dos seres humanos e maturidade da humanidade.

a) Feuerbach ${ }^{150}$, partindo de sua antropologia humanista e materialista, a teoria feuerbachiana da alienação alega que a fé em Deus é produto da projeção da mente humana.

b) Karl $\operatorname{Marx}^{151}$ e seu ateísmo sociológico, nascido “da confluência do materialismo da ciência natural com o socialismo francês, penetrada e animada pelo espírito dialético de Hegel" ${ }^{" 152}$, a religião é alienante e instrumento de opressão e dominação.

d) Para Freud ${ }^{153}$ e seu ateísmo psicanalítico, influenciado por Darwin ${ }^{154}$, a religião é atribuição ao ser divino da figura paterna, onde encontra ingenuamente proteção e consolação, logo, uma ilusão infantil, uma neurose obsessiva.

c) Nietzsche apresenta seu ateísmo niilista, onde a religião é um erro da razão e das instituições religiosas promotoras das suas mentiras doentias, sendo o cristianismo uma tentativa de negar o mundo e os desejos ordinários inerentes da natureza humana. E com a mesma intensidade Nietzsche alega que toda metafísica

\footnotetext{
${ }^{148}$ No entanto, pode-se argumentar que, a postura inversa foi que desencadeou as controvérsias.

${ }^{149}$ ZILLES, Urbano, op. cit., p. 14.

${ }^{150}$ Em Feuerbach: "o ser absoluto do homem, o Deus do homem, é a sua própria essência”; "a consciência de Deus é a consciência de que o homem tem de si mesmo"; "a religião é a primeira consciência do homem de si mesmo" (FEUERBACH, Ludwig. A essência do cristianismo. Campinas: Papirus, 1988, p. 47; 55; 309).

${ }^{151}$ Em Marx: "a religião é o suspiro do ser oprimido, o íntimo de um mundo sem coração e a alma de situações sem alma. É o ópio do povo" (MARX, Karl. Manuscritos econômicos e filosóficos. São Paulo: Martin Claret, 2001, p. 45-46).

152 ZILLES, Urbano, op. cit., p. 121.

${ }^{153}$ Em Freud: "nada do que eu disse aqui sobre o valor de verdade das religiões precisa de apoio na psicanálise; já foi dito por outros muito antes que a psicanálise surgisse" (FREUD, Sigmund. Os pensadores. São Paulo: Abril S/A cultural e Industrial, 1978, p. 112).

${ }^{154} \mathrm{Na}$ esteira de Darwin, vemos um naturalismo mais rigoroso, com pouco espaço para razão humana que é dirigida por um lado pelo instinto e por outro pelas exigências de sobrevivência, podendo consistir em usos instrumentais da razão (Cf. TAYLOR, Charles, op. cit., p. 22).
} 
deveria ser recusada ${ }^{155}$. O ser humano terá que viver pelo que acredita em si mesmo. Entretanto, a consciência do niilismo deixado por esta nova postura não se aproximará sem uma crise de consciência ${ }^{156}$.

\subsection{3}

\section{A repressão da religião e da expressão religiosa}

Um grande desafio para fé cristã se constitui no embate que tem sido travado, ao longo das últimas décadas, referente à abordagem negativa feita por psicólogos, psicoterapeutas e psiquiatras dos fenômenos religiosos, onde estes fenômenos são enquadrados numa categoria patológica e marginal. A repressão realizada por estas áreas do conhecimento às formas religiosas apresenta uma imagem regressiva e repressiva da concepção de Deus.

$\mathrm{Na}$ esteira de Freud, as teorias oriundas da psicologia profunda, deslocam causas espirituais para a esfera da mente, onde se falava em possessão demoníaca, agora se fala em doença mental, transferindo-se questões do registro espiritual para o registro terapêutico. Desta forma, as noções psicológicas de patologia mental não abordam em sua etiologia o espiritual. A cura não envolve a conversão, mas psicoterapia. ${ }^{157}$

\subsection{4 \\ Modos pós-modernos de crítica}

Estes modos de críticas pós-moderna, atacam e ridicularizam as afirmações da razão autossuficiente e também as posturas que criticam a autossuficiência da razão. Porém, sem oferecer uma fonte de poder externo. Em geral parecem sublinhadas suas convicções ateístas, enfatizam a irremediável ruptura da natureza, a falta de centro, e a ausência perpétua de plenitude. A busca da plenitude é considerada, nestes modos de críticas, sendo no máximo um sonho

\footnotetext{
${ }^{155}$ Em Nietzsche: "o velho Deus Cristão morreu” (NIETZSCHE, Friedrich. A gaia ciência. São Paulo: Companhia das letras, 2001, p. 234); "Super-homem é todo aquele que supera as oposições terreno-extraterreno, sensível-espiritual, corpo-alma; é todo aquele que supera a ilusão metafísica do mundo do além e se volta para a terra, dá valor à terra" (Id., Assim falou Zaratustra. São Paulo: Martin Claret, 2000, p. 46).

${ }^{156}$ E quando esta crise surgir, em tom profético, diz Nietzsche: "sei que algum dia o meu nome estará relacionado, em recordação, a algo terrível, a uma crise como nunca ocorreu, a mais terrível colisão de consciências, a uma sentença anunciada contra tudo aquilo que se acreditava, exigia e santificava até então" (Id., Ecce Homo. São Paulo: Martin Claret, 2000, p. 117).

${ }^{157}$ Cf. TAYLOR, Charles, op. cit., p. 725-726.
} 
necessário para conferir sentido à existência humana, plenitude que por princípio jamais será encontrada. Apesar de se posicionarem contra a razão desengajada e da autossuficiência da razão, são tão ou mais hostis à religião. ${ }^{158}$

\subsection{5}

Posturas intrínsecas ao ser cristão e suas instituições

No Ocidente, marcado pela cultura judaico-cristã, a partir da Modernidade e sua sociedade em processo de secularização e globalização, houve profundas mudanças que influenciaram as Igrejas e o comportamento cristão. Tanto pela senda católica, quanto pela protestante em suas instituições históricas, e posteriormente nas instituições das correntes pentecostais, deuteropentecostais ${ }^{159}$ e neopentecostais. Mudanças que afetaram a postura intrínseca destas instituições, da individualidade cristã, das comunidades de fé e o relacionamento destas com a sociedade.

Diante dos impactos das transformações culturais e estruturais da sociedade, as Igrejas cristãs necessitam dialogar com o mundo para atualizar e contextualizar suas estruturas e cumprir sua missão.

1. Igreja Católica: estrutura interna e relacionamento com a sociedade. A Igreja Católica se encontra diante de pressões internas e externas que apelam para uma avaliação de possibilidade para mudanças, tanto em sua estrutura interna, quanto em seu relacionamento com a sociedade. A Igreja afirma ser uma instituição de comunhão na qual os cristãos deveriam plasmar-se, sem viver e oferecer esta realidade em sua própria esfera torna esta afirmação inócua e ineficaz. Não basta mobilização e apelo para conversão das mentes, sendo as estruturas da Igreja arcaicas e influenciando negativamente a própria compreensão dos fiéis, que percebem e experimentam o descompasso da Igreja com o nosso tempo. ${ }^{160}$ Este descompasso se torna abissal quando a Igreja se dirige a toda sociedade que, hoje, se configura secularizada, globalizada e afirmando a

\footnotetext{
${ }^{158}$ Cf. Ibid., p. 23.

${ }^{159}$ Nomenclatura adotada por Mariano para designar a secunda onda do pentecostalismo no Brasil, isto é, "um desdobramento institucional tardio, em solo brasileiro, do pentecostalismo clássico norte-americano" (MARIANO, Ricardo. Neopentecostais: Sociologia do novo pentecostalismo no Brasil. 2. ed. São Paulo: Loyola, 2005. p. 31-32), já sendo classificadas, anteriormente a Mariano, como igrejas da "Cura Divina".

${ }^{160}$ Cf. MIRANDA, Mário de França. Igreja e sociedade. São Paulo: Paulinas, 2009, p. 6-7Coleção sinais dos tempos.
} 
autenticidade e pluralidade de suas expressões individuais, culturais e religiosas. ${ }^{161}$ Procurando adaptar-se aos novos tempos em sua estrutura e missão, com o aggiornamento, buscou maior envolvimento com a sociedade e uma elaboração teológica de interação com realidade social, porém, esta postura não levou a mesma a um processo intrínseco de secularização, ainda que passos tenham sido dados neste sentido.

2. A senda protestante: comportamento imerso na secularidade. A mudança no sentido de absorver um comportamento profundamente secularizado se faz presente na senda ${ }^{162}$ protestante, tanto em suas expressões institucionais quanto individuais, que se encontram imersas na secularidade. Necessitando de reorientação, por estarem imersas na secularização de seus comportamentos e perspectivas, apresentando características que são alheias aos ensinos neotestamentários. Este comportamento se faz mais nítido nas correntes pentecostais, sendo a identidade e a força vital do neopentecostalismo que, muitas vezes, para dar respaldo a sua expressão, estabelece uma hermenêutica bíblica fundamentada nos propósitos eclesiais e pessoais desta liderança, produzindo sua própria versão de Jesus Cristo, isto é, um Jesus domesticado. No entanto, apesar da secularização do seu comportamento, paradoxalmente, este nicho, como outros, da senda protestante, mantêm sua compreensão fundamentalista da Bíblia para respaldar algumas de suas doutrinas e os resultados mágicos para solução dos problemas existências, financeiros, espirituais, psicológicos e de âmbito interpessoal.

a) A concepção utilitarista e triunfalista da religião. No âmbito individual, no catolicismo, existe na concepção de muitos cristãos a noção de uma religião utilitarista condicionada à realização humana, numa expressão secularizada. No entanto, esta compreensão utilitarista se encontra, intimamente, relacionada à identidade protestante, em suas diversas ramificações. Estabelecendo sua própria hermenêutica para fundamentar os propósitos eclesiais e da liderança, principalmente na vertente pentecostal e neopentecostal, no entanto, este comportamento pode já ser visto dando seus passos em algumas Igrejas históricas. Apresentam uma visão triunfalista diante da realidade, recusando e negando os

\footnotetext{
${ }^{161}$ Cf. Ibid., p. 9-36.

${ }^{162}$ Para aprofundar a classificação: MENDONÇA, Antônio Gouvêa; FILHO, Prócoro Velasques.
} Introdução ao Protestantismo no Brasil. 2. ed. São Paulo: Loyola, 2002, p. 11-58. 
fatores negativos que podem acometer os seres humanos, como a tristeza, a dor, o fracasso e a morte. $\mathrm{O}$ neopentecostalismo associa à sua práxis institucional uma organização empresarial, recorrendo à trama capitalista para o aumento do seu mercado de adeptos, apelando a membros de outras denominações num espírito ferrenho e contundente de concorrência e competição, estabelecendo o mercado religioso e eclipsando a religiosidade autêntica que aponta para verdadeira fonte transcendente. Obscurecendo, consequentemente, a experiência pessoal do encontro com Deus e o fascínio que envolve o ato e a vivência da fé diante do mistério, isto é, uma ruptura e descompasso com essência do cristianismo. Apresentando assim, uma cosmovisão individualista na relação com o outro e, consequentemente, com a comunidade de fé e a sociedade. $\mathrm{O}$ movimento neopentecostal exerce influencia sobre as demais igrejas da senda protestante, pentecostais e históricas, no seu apelo ao agrado às massas e na busca de projeção, o que sinaliza um futuro ainda mais instável para a esteira protestante em relação à essência do cristianismo. ${ }^{163}$ Este caminho tem sido percorrido a passos largos, sendo fruto da ideologia capitalista, tornando a religião egocêntrica, materialista e consumista. $^{164}$

3. Ruptura e descompasso: institucional versus individual. A atual configuração religiosa permite observar uma ruptura e descompasso no universo institucional e individual cristão. Existindo a necessidade de superação deste quadro pelas Igrejas cristãs, católicas e protestantes, principalmente, em relação às expressões concentradas na subjetividade e ao senso de pertencimento.

a) Expressões imersas na subjetividade. Postura observada principalmente na vertente pentecostal e neopentecostal. Sendo esta realidade mais atenuada no catolicismo, porém, nesta senda é enfatizada pelo movimento de Renovação Carismática Católica (RCC). Perspectiva que possui como característica básica uma religiosidade fundamentada na erupção emotiva que culmina em êxtase que é atribuído a ação do Espírito Santo.

\footnotetext{
${ }^{163}$ Para uma leitura pela apologética cristã do neopentecostalismo: GONDIM, Ricardo. O evangelho da nova era: uma análise e refutação bíblica da chamada teologia da prosperidade. 3 ed. São Paulo. ABBA, 1995; ROMEIRO. Paulo. Supercrentes: o evangelho segundo Kenneth Hagin, Valnice Milhomens e os profetas da prosperidade 6. ed. São Paulo: Mundo Cristão, 1998. Para uma leitura sociológica desta realidade: MARIANO, Ricardo. Neopentecostais: sociologia do novo pentecostalismo no Brasil. São Paulo: Loyola, 2005.

${ }^{164}$ Cf. GONDIM, Ricardo, op. cit., p. 9.
} 
b) O descompasso do crer sem pertencer. A expressão religiosa individualizada absorvida e desenvolvida devido a várias possibilidades de disponíveis na atual sociedade que, no entanto, divergem em relação às perspectivas institucionais $\mathrm{O}$ "crer sem pertencer" aponta para uma das complicações cruciais do cristianismo, advinda deste modo de vivência da fé. A transmissão regular dos valores e tradições proporcionada pelas instituições, de uma geração a outra é a condição para toda sociedade sobreviver através do tempo. ${ }^{165}$ Quando esta transmissão não se estabelece de forma adequada, surge deste modo de crer a dificuldade de comunhão, propósitos, perspectivas e identidade entre os indivíduos de uma determinada comunidade de fé, e entre estes e sua instituição, emergindo, como consequência, o enfraquecimento do universo simbólico cristão e uma religiosidade não eclesial. ${ }^{166}$

\subsection{6 \\ O grande desafio: uma proposta de orientação cristã}

O desafio das igrejas e comunidades cristãs, católicas e protestantes, consiste em oferecer uma proposta de orientação básica cristã para atual sociedade secular, através da mensagem salvífica do Reino de Deus. Proclamando a ação salvífica de Deus, que se manifestou em plenitude na pessoa e vida de Jesus de Nazaré. Porém, este desafio torna-se mais complexo e desafiador devido a três modos que sustentam o ser da atual sociedade: o pluralismo, o individualismo e a liberdade de escolha. Estes modos alegam para si genuinidade, autenticidade e reconhecimento de suas expressões. O primeiro consiste na realidade plural da atual sociedade em sua multiplicidade de experiências religiosas, espiritualidades e demais religiões. O segundo estabelece a cultura da autenticidade, ou do individualismo expressivo, onde cada um deve buscar a sua própria forma de viver e se relacionar. O terceiro modo, interligando estas duas realidades anteriores, apresenta a questão da liberdade de escolha, isto é, a pura liberdade de escolha como valor primário, como regularmente é invocado em nossa sociedade. No entanto, este argumento trivializa questões cruciais, escondendo quase tudo que deve ser levado em consideração em relação ao peso moral das situações em

\footnotetext{
${ }^{165}$ Cf. HERVIEU-LÉGER, Daniele, op. cit., p. 34; 57.

${ }^{166}$ Cf MIRANDA, Mário de França. Um homem perplexo: o cristão na atual sociedade. 3. ed. São Paulo: Loyola 1996. p. 15-16; 18-19.
} 
questão. A mudança provocada pela cultura, promovendo a relativização da castidade, da monogamia e afirmação da homossexualidade, causou profundo impacto sobre as Igrejas cristãs e, consequentemente, em sua pastoral, principalmente a dificuldade em dialogar com as pessoas, proeminentemente as mais jovens, que nutrem esta mentalidade. ${ }^{167}$

\subsection{7}

\section{A necessidade do diálogo ecumênico e inter-religioso}

A respeito do diálogo ecumênico e inter-religioso, a Igreja Católica ${ }^{168}$, com o Concílio Vaticano II, procurou um aggiornamento da Igreja que incluía esta finalidade. No entanto, algumas intuições em torno do ecumenismo e do diálogo inter-religioso necessitam avançar para dar fruto a sua semente, colocando, principalmente, a questão salvífica das religiões não cristãs. ${ }^{169}$ Não sendo "pensável um cristianismo no futuro fora do diálogo ecumênico e interreligioso." 170 Enquanto, no catolicismo a semente foi lançada, e os primeiros passos foram dados neste sentido, o mesmo não pode ser dito da maioria das Igrejas da senda protestante instaladas no Brasil, onde ainda impera intolerância, radicalizações e fundamentalismo.

\subsection{8}

\section{A emergência de um ethos mundial para justiça e paz}

A necessidade de um ethos mundial de paz e justiça para o presente e futuro da humanidade, não deve prescindir da busca do diálogo ecumênico e interreligioso. Objetivo que deve ser buscado tanto por religiosos quanto pelas esferas seculares.

A atual realidade se encontra numa configuração conflituosa que apresenta questões globais éticas, morais, políticas, econômicas e religiosas que pressionam,

\footnotetext{
${ }^{167}$ Cf. TAYLOR, Charles, op. cit., p. 555-592.

${ }^{168}$ Verificar a postura da Igreja sobre o diálogo com outras religiões em: Comissão Teológica Internacional. O cristianismo e as religiões. São Paulo: Loyola, 1997, fruto das sessões plenárias realizada em Roma em 1993, 1994 e 1995, sendo este texto aprovado em 1996.

${ }^{169}$ Cf. MIRANDA, Mário de França. Igreja e sociedade, op. cit., p. 107-108. Lumen Gentium 16 "As relações da Igreja com relação com cristão não-católicos"; e 17 "Os não-cristãos". E Gaudium et Spes 22. No entanto, não entrou na questão da legitimidade salvífica das religiões não cristãs, conforme Nostra Aetate n. 2: "a Igreja Católica não rejeita o que é verdadeiro e santo em todas as religiões”, perspectiva em: Id., Um homem perplexo, op. cit., p. 60-69.

${ }^{170}$ LIBÂNIO, João Batista. Olhando para o futuro: prospectivas teológicas e pastorais do cristianismo na América Latina, São Paulo: Loyola, 2003, p. 95.
} 
cada vez mais, a sociedade para posturas que confrontam a concepção do comportamento humano e social defendida pelo cristianismo. Esta complexa e intrincada realidade se encontra sob as influências da cultura plurirreligiosa hodierna, dos processos de globalização e secularização. Realidade que utilizadas por interesses políticos e socioeconômicos podem desencadear consequências catastróficas para humanidade. Esta ameaça suscita a urgência de um ethos global. $^{171}$

${ }^{171}$ Cf. HERVIEU-LÉGER, Danièle, op. cit., p. 175-238; verificar também: KÜNG, Hans. Projeto de ética mundial: uma moral ecumênica em vista da sobrevivência humana. 3. ed. São Paulo: Paulinas, 2003. Id., Para que um ethos mundial? Religião e ética em tempos de globalização. Conversando com Jürgen Hoeren. São Paulo: Loyola. 2005. 


\section{Hans Küng: trajetória e reflexões de um teólogo ecumênico}

Hans Küng possui um papel preponderante na teologia cristã. Reconhecido como um dos teólogos mais influente em ação no século XIX. Seus escritos tem como principal finalidade apresentar propostas para que a Igreja Católica e demais Igrejas cristãs, possam, de forma coerente e contextualizada, viver, transmitir e expressar a mensagem salvífica de Deus, na tradição judaico-cristã, à sociedade moderna. Salienta, em suas obras, que o fenômeno da secularização possui sua ênfase no mundo ocidental, pois em diversas partes do mundo a religião ainda influencia a sociedade sendo necessário reconhecer sua ação.

\section{1}

\section{Traços biográficos}

Nascido em Sursee, Suíça, em 19 de março de 1928. Oriundo de uma família católica, estudou na cidade de Lucerna, morando, posteriormente, sete anos em Roma, Collegium Germanicum et Hungaricum. Estudou filosofia e teologia na Pontifícia Universidade Gregoriana. Foi ordenado sacerdote, em 1954. Celebra a eucaristia, pela primeira vez, em São Pedro. Em 1957, tendo recebido o título de doutor pelo Instituto Catholique em Paris, com a tese Justificação, que traz como subtítulo: A doutrina de Karl Barth e uma reflexão católica. Em 1960, aos trinta e dois anos, torna-se professor de teologia na Universidade Católica de Tübingen, lecionando na mesma até 1990. E ainda com esta idade, foi convidado para participar do Concílio Vaticano II (1962-1965), como especialista, peritus, nomeado por João XXIII. Em 1963 fundou o Instituto de Pesquisa Ecumênica, do qual foi diretor.

Em 1970, publicou a obra Infalivel? Uma pergunta, onde criticou severamente o dogma da Infabilidade Papal, publicando-a exatamente em 18 de janeiro de 1970, no centenário da declaração da infabilidade, realizada pelo Concílio Vaticano I. Nesta crítica, apresenta os motivos para rejeição do caráter infalível do ensino da Igreja e das decisões papais.

Em 1979, foi publicado nos principais jornais do mundo o artigo intitulado Um ano de João Paulo II, no aniversário da eleição deste pontífice. Este artigo foi o "documento-chave" para sua cassação meses depois. Criticando sua linha de 
conservadorismo e restauração, postura que, para o teólogo suíço-alemão, proporcionou o afastamento de muitos católicos da Igreja. Küng esclarece que, após seu livro Infalível?, esperava uma saraivada de críticas críticas, mas não esperava o ataque de amigos teólogos como Karl Ranher. ${ }^{172}$ Ainda em 1979, sobre o papado de João Paulo II, Karol Wojtyla, teve a autorização para lecionar ${ }^{173}$ cassada pela Igreja, no entanto, conserva a cadeira de professor na Universidade de Tübingen que o nomeou para lecionar teologia ecumênica. Manteve também seu Instituto, este separado da Faculdade Católica. Em 2011, criticou a beatificação deste papa. ${ }^{174}$

Ao se aposentar em 1996, tornou-se presidente da Fundação Ética Global em Tübingen. Celebrou, em 10 de outubro de 2004, o jubileu de cinquenta anos de seu sacerdócio.

Em sua tese de doutoramento Küng, confronta a doutrina da justificação, na perspectiva de Karl Barth, com a doutrina católica na perspectiva do Concílio de Trento. O objetivo não era a confrontação apologética, mas uma investigação que resultou na compreensão de que ambas as doutrinas tratavam da mesma coisa, no entanto, cada uma com sua tendência e com seu próprio sistema categorial, isto é, baseavam-se em estruturas de pensamentos diferentes. Enquanto a teologia católica expressava-se de acordo com escolástica aristotélica, Barth, por sua vez, expressava sua perspectiva a partir do idealismo alemão. Küng por sua tese recebe uma consideração simpática por parte de Karl Barth. A partir desta tese, inicia seu itinerário teológico que avançaria da teologia ecumênica à teologia das religiões.

A partir da década de 60, o jovem Küng, adotou uma postura crítica e contundente à Igreja Católica Romana. Em 1960 escreve a Reforma da Igreja e a Unidade dos Cristãos; em 1962, Estruturas da Igreja; e A Igreja, em 1967. Obras onde descreve a necessidade do perfil humilde e fiel mensagem de Jesus de Nazaré ser incorporado pela Igreja, com total disposição de sempre se reformar quando houver necessidade. Em A Igreja apresentou também sua eclesiologia

\footnotetext{
${ }^{172}$ Cf. KÜNG. Hans. A Igreja Católica. Rio de Janeiro: Objetiva. 2002, p. 15; 234-345; 237.

${ }^{173}$ A missio canônica, isto é, a licença para ensinar como teólogo católico, que é perda da autorização eclesiástica impedindo-o de lecionar em faculdades católicas. Esta sanção provocou grande polêmica internacional. Nesta época o colega de Küng, no Concílio Vaticano II e na Universidade de Tübingen, Joseph Ratzinger, atual Papa Bento XVI, estava à frente da Congregação Para Doutrina da Fé.

${ }^{174}$ Questionamento apresentado por Küng à emissora alemã Deutschlandfunk. Detalhes estão disponíveis em: http://www.teleios.com.br/2011/hans-kung-teologo-alemao-questionabeatificacao-de-joao-paulo-2\%C2\%B0/. Acesso em: 28 de abr. 2012.
} 
analisando a Instituição não apenas como uma construção social, e nem como uma essência atemporal, mas como uma realização histórica que pode andar de acordo ou em desacordo com os dados neotestamentários.

Em 1978, em sua extensa obra Existe Deus? Resposta ao problema de Deus em nosso tempo apresenta argumentos favoráveis à existência de Deus. Na obra Ser Cristão, 1974, ancorado pelo método histórico crítico e não se fundamentando em formulas abstratas, mas a partir da concretude neotestamentária apresenta figura de Jesus de Nazaré e seu significado na vida do cristão.

Em 1982, na obra Vida eterna?, aborda a questão da vida após a morte e a legitimidade de sua fundamentação. Publica, em 1984, O cristianismo e as grandes religiões, onde o cristianismo dialoga com o islamismo, o hinduísmo e o budismo. Nas obras, O judaísmo, 1991; O cristianismo, em 1992; e O Islamismo, em 2004, apresenta minuciosos estudos sobre estas religiões.

Na obra Teologia a caminho, 1987, constata que a atual teologia está exposta a uma mudança de paradigma. Descreve que o paradigma teológico pósmoderno avança assumindo o lugar dos paradigmas teológicos anteriores, isto é, os paradigmas da Idade Média, da Reforma e da Modernidade. Aborda o paradigma pós-moderno em suas dimensões históricas, bíblicas, ecumênicas e políticas. O objetivo do autor é contribuir para elaboração de uma teologia ecumênico-crítica.

No livro O princípio de todas as coisas. Ciências naturais e religião, 2007, o autor apresenta a relação e a problemática do entrecruzamento da ciência e religião, ocupando-se com perguntas fundamentais sobre a existência: Por que existe alguma coisa e não o nada? Qual a origem do mundo e do homem? Não deixando de lado o livre arbítrio e a consumação do universo. Em 2011, escreve sobre suas esperanças e utopias na obra Em que eu creio.

No livro Projeto de ética mundial, 1990, defende a necessidade de um consenso ético básico sobre determinados valores, normas e atitudes. Declarando ser impossível uma convivência humana digna sem estes valores elementares na sociedade. Afirma que para alcançar este objetivo, será necessário o diálogo e o mútuo reconhecimento entre as religiões e entre as nações. O projeto de ética mundial deve partir do pressuposto da dignidade humana como base para a sociedade. 
Hans Küng, por um longo tempo vem se dedicando a propor a necessidade de uma postura ecumênica. Em seus estudos de doutoramento vislumbrou a possibilidade desta realidade, inicialmente com o luteranismo. O desdobramento desta postura foi dedicar-se, como teólogo, à elaboração de uma proposta para a transformação político-religiosa através de um ethos mundial focando a paz entre as civilizações, sobre tudo por meio do diálogo inter-religioso no mundo globalizado.

Em 1979, três anos após a morte de Mao, foi o primeiro teólogo cristão a receber permissão para falar em Pequim, na Academia de Ciências Sociais, sobre religião e fé em Deus. Em 1989, recebeu a incumbência para redigir o texto básico para o Primeiro Diálogo das Religiões da UNESCO. Em 4 de setembro de 1993, no Parlamento das Religiões Mundiais, em Chicago, apresentada a declaração sobre os princípios do ethos mundial. Esta declaração foi assinada por representantes de diversas religiões. Na ocasião, o Dalai Lama, foi o primeiro a colocar a sua assinatura na declaração. As ideias do projeto do ethos mundial, por sua relevância, alcançaram o nível das Nações Unidas.

Küng declara que a retirada da sua licença eclesiástica para lecionar, permitiu-lhe tempo para dedicar-se as questões das religiões mundiais. Assuntos de se interesse, desde seus estudos em Roma, de 1948-1955. Alega que o seu currículo teológico não foi planejado por ele mesmo. E que após seu doutoramento em teologia pretendia doutorar-se em filosofia, em Paris, tendo para tal propósito um manuscrito sobre Hegel, quase pronto. Porém adiou o projeto por ter recebido e aceito o convite para lecionar em Tübingen, e em seguida ter sido chamado para ser acessor teológico durante o Concílio Vaticano II. ${ }^{175}$

Küng elege seus livros, Ser cristão, Deus Existe? e Vida Eterna?, como fundamento de seu trabalho teológico. Alega que, até a atual data, não precisou rever nenhuma de suas posturas. Afirma que a fundamentação segura da teologia cristã deu-lhe confianças de que sempre lhe ocorreria uma resposta aos questionamentos vindos por parte das outras religiões. E que do diálogo com seus colegas de Tübingen lhe ocorreu a ideia de paz entre as religiões como base da paz entre as nações. Lembra que, esta ideia já fora formulada em 1984, muito antes de Samuel P. Huntington ter chamado a atenção com artigo "Clash of civilizations".

\footnotetext{
${ }^{175}$ Cf. KÜNG, Hans. Para que um ethos mundial?, op. cit., p. 17-18.
} 
Alega que foram outros que o desafiaram a refletir sobre padrões éticos comuns na atualidade, e ele tentou dar respostas. ${ }^{176}$

Apesar de sua crítica à Igreja Católica Romana, em 2005, Joseph Ratzinger, o atual papa Bento XVI, surpreendendo a opinião pública mundial, recebeu Küng para uma conversa amigável na residência de Castel Gandolfo, onde dialogaram sobre teologia, celibatos dos padres, contracepção e o papel da mulher na Igreja católica. Momento em que Küng agradece a Bento XVI pela possibilidade de diálogo em seu pontificado. No entanto, posteriormente a este encontro, mesmo que os ânimos estivessem mais calmos, a postura contundente de Küng permanece.

Em 2009, na publicação de parte de suas memórias, alega que aguardava viver a sucessão de João Paulo II. Esperava, como muitos, que na sucessão surgisse um papa na linha João XXIII. Na ocasião da sucessão, o papa eleito foi Joseph Ratzinger, fato que levou Küng a declarar que a sua expectativa se cumpriu, mas num sentido totalmente contrário. ${ }^{177}$ No dia da entrega do décimo quinto doutorado Honoris Causa à Küng outorgado pela Uned (Espanha), o crítico do pontificado de João Paulo II alega em relação a Joseph Ratzinger: "Eu terminei perdendo a licença docente eclesiástica em 1979, mesmo que continuando dando aulas. Ele, por outro lado, se converteu em papa, tornando-se, certamente, mais falível."178 Küng solicitou aos bispos que permanecessem fieis ao papa e simultaneamente expressarem suas críticas, devendo eles mesmos serem responsáveis em promover a reforma da Igreja, que só poderá acontecer obedecendo mais a Deus do que aos homens, como também, ser mais fiel a Deus e ao Evangelho do que ao papa. ${ }^{179}$

\footnotetext{
${ }^{176}$ Cf. Ibid., p. 19.

${ }^{177}$ Encontrado no jornal espanhol El País, 08 de mar. 2009, que publicou alguns extratos de Verdade controvertida, segunda parte das memórias de Hans Küng, livro editado na Espanha pela Editorial Trotta. A tradução é do Cepat. Disponível em: http://www.ihu.unisinos.br/noticias/noticias-arquivadas/20555-a-verdade-de-hans-küng. Acesso em: 28 de abr. 2012.

${ }^{178}$ A reportagem é de Jesús Bastante, publicada no sítio Religión Digital, 28 de jan. 2011. A tradução é de Anne Ledur e revisada pela IHU On-Line. Disponível em: http://www.ihu.unisinos.br/noticias/40287--hans-kueng-ratzinger-se-converteu-em-papa-tornandose-certamente-mais-falivel. Acesso em: 28 de abr. 2012.

${ }^{179}$ Conforme reportagem da revista alemã The European, 05 de maio. 2010. A tradução é de Benno Dischinger. Disponível em: http://www.ihu.unisinos.br/noticias/noticias-arquivadas/32183tenho-simpatia-pelo-homem-joseph-ratzinger-entrevista-com-hans-kueng. Acesso em: 28 de abr. 2012.
} 
A postura crítica e contundente de Küng à sua Igreja Mátria permanece até nossos dias. No entanto, não deixa de citar a importância da mesma na história e para a perpetuação do cristianismo, enfatizando sua postura em relação à Igreja; "quero deixar claro, desde início, que, apesar de todas as minhas experiências de quão implacável pode ser o sistema romano, a Igreja Católica, esta associação de crentes, até hoje continua sendo meu lar espiritual"180. Também não deixa de declarar: "por mais de duas décadas permaneci firmemente fiel à minha em lealdade crítica, e até hoje sou professor catedrático de teologia ecumênica e sacerdote católico em boa situação"181 . E continua: "afirmo o papado para a Igreja Católica, mas ao mesmo tempo preconizo uma reforma radical dessa instituição de acordo com o critério do evangelho" ${ }^{\text {182 }}$. Afirma ser padre como antes, com todos os poderes e funções que a ordenação sacerdotal o conferiu, sempre servindo a sua Igreja, entendendo que suas críticas à instituição era um serviço, sendo um cristão e um católico crítico.

Küng, sempre declarou que sua espiritualidade busca mais racionalidade do que sensibilidade, mas ao mesmo tempo alega que a problemática do mundo secularizado não pode ser reduzida apenas a racionalidade e funcionalidade, mas deve ser avaliada em sua dimensão mais profunda, para que se encontrem respostas sólidas sobre a fundamentação da vida, pretendendo que a fé em Deus seja também compreendida e não só aceita, muito menos imposta.

Possui mais de uma dezena de doutorados Honoris Causa, o primeiro aos trinta e quatro anos de idade na Universidade de Sant Louis, em Missouri, Estados Unidos. Um destes doutorados, o décimo quinto, foi outorgado pelo teólogo e filósofo Manuel Fraijó, na Universidade Nacional de Educação a Distância-Uned, em 27 de janeiro de 2011, sendo o primeiro recebido por Küng na Espanha. Além de destacado teólogo, apresentou notáveis serviços à filosofia, especialmente à filosofia da religião. Seus livros somam mais de 50 títulos que ultrapassam juntos mais de trinta mil páginas, numerosas edições e traduções para os principais idiomas. Em setembro de 2005 a revista Foreign Policy Spectator o incluiu na lista dos 100 intelectuais mais influentes do mundo.

\footnotetext{
${ }^{180}$ KÜNG. Hans. A Igreja Católica, op. cit., p. 15.

${ }^{181}$ Ibid., p. 16.

${ }^{182}$ Ibid., p. 16.
} 
Küng anunciou sua aposentadoria do cenário mundial para 2013, no entanto, sua casa, em Tübingen, repleta de livros, continuará hospedando e sediando a fundação Weltethos, cujo escritório brasileiro tem sua sede no Instituto Humanitas Unisinos. Porém, alega que permanecerá presente através da mídia e publicará o terceiro volume de memórias neste mesmo ano. Hoje, aos 84 anos, é professor emérito de ecumenismo em Tübingen e por motivos de saúde raramente viaja.

Conscientemente alega que está pronto para o fim da sua vida terrena, pois viveu sete vidas, não se permitindo nenhuma nostalgia. Diz estar curioso, pois a morte é a primeira para todos. Tendo a certeza de que não cairá no nada, pois acredita na vida eterna. E quando perguntado sobre o que diria a Deus se o perguntasse sobre o que fez para tornar o mundo melhor, Küng responde: "sei que Ele não me fará essa pergunta, porque Ele sabe disso sem me perguntar" ${ }^{\prime 183}$.

As reflexões de Hans Küng serão abordadas sobre questões que possibilitarão aproximar-se da compreensão deste teólogo, sobre alguns temas fundamentais relacionados ao ser humano, ao mundo, a religião e ética.

\section{2}

\section{A visão integral do ser humano: determinismo versus liberdade}

Para compreender o ser humano em suas peculiaridades, será necessário, para evitar equívocos, perceber a sua existência de forma global e integrada. Para este propósito deve-se abordar o ser humano considerando seu cérebro, seu espírito, e a questão do determinismo ou liberdade de suas ações.

Küng esclarece ser necessário, para este propósito, inicialmente superar o exacerbado dualismo corpo-e-alma que chegou até nós, passado por Platão, Agostinho e principalmente por Descartes. O ser humano deve ser visto como unidade inseparável de psique e corpo, isto é, "como conjuntos de processos emocionais ('anímicos') conscientes inconscientes e das funções espirituais (intelectuais)" ${ }^{\text {"184 }}$. Corpo e psique, cérebro e espírito não podem ser separados, pois constituem uma unidade psicossomática, não existindo no ser humano

\footnotetext{
${ }^{183}$ A reportagem é de Arno Luik, publicada na revista alemã Stern, 15 de out. 2009. A entrevista publicada em alemão foi traduzida do italiano por Moisés Sbardelotto. Disponível em: http://www.ihu.unisinos.br/noticias/noticias-arquivadas/26676-\%60\%60vivi-sete-vidas-nao-tenhomedo-de-morrer\%60\%60-entrevista-com-hans-k\%C3\%BCng. Acesso em: 28 de abr. 2012.

${ }^{184} \mathrm{KÜNG}$, Hans. O princípio de todas as coisas: ciências naturais e religião. 2. ed. Petrópolis: Vozes, 2009, p. 231.
} 
atividade espiritual sem um substrato neurônico. No entanto, isso não significa que o espírito não passa de uma atividade secundária da atividade cerebral, e nem que a liberdade do homem é condicionada ${ }^{185}$. Com o resultado das pesquisas comportamentais percebe-se mais claramente que o homem é duplamente préformado, tendo que levar em consideração o ambiente e as tendências hereditárias. No entanto, como enfatizam os etnólogos, e o próprio Skinner não negava a liberdade humana, o inato não age como predominante, nem inevitável, isto é, o homem não é nem totalmente programável pela aprendizagem nem préprogramado, mas sim, uma interação, dada as condições normais. ${ }^{186}$

A capacidade de livre-arbítrio volta a ser questionada pela neurofisiologia do cérebro, esta ciência transforma a problemática espírito e corpo, exacerbando-a em espírito e cérebro. Küng admite que o espírito é um produto da evolução, sem o cérebro não existe espírito, e sem determinados centros cerebrais não é possível existir realização espiritual. Porém, isso não significa que o ser humano é determinado pelos processos físico-químicos do cérebro, que sempre antecipam a nossa vontade fazendo do livre arbítrio uma ilusão. Postura que é uma grave derivação dos conhecimentos dos neurofisiologistas, que atribuem as decisões ao mecanismo do sistema límbico. Porém, a consequência da aplicação deste pressuposto, assombroso e superficial ao direito e a ética deprecia a responsabilidade e a culpa humana, permitindo um álibi científico para os mais hediondos crimes, sendo estas declarações irresponsáveis e reducionistas. ${ }^{187}$

No entanto, essas pesquisas e declarações são inconclusivas pela própria limitação da pesquisa cerebral, principalmente por não superarem as lacunas entre processos físicos e a consciência. As pesquisas atuais demonstram existir um grande desconhecimento em níveis mais importantes das atividades cerebrais. Estas pesquisas jamais permitiriam afirmar ser o livre arbítrio uma ilusão. Acrescente-se a isso, a dimensão histórica, política e social que não pode ser reduzida a processos cerebrais e que, diante da correnteza dos fatos, indicam a existência do livre arbítrio ligado à autonomia do eu. Este eu que não pode ser

\footnotetext{
${ }^{185}$ Conforme pretendido pelo Iluminismo francês do século XVIII, com o homem-máquina de Lametrie, e os marxistas-racionalistas, influenciados por Engels e Haeckel - postura combatida pelo existencialismo francês do século XX - defendendo que a liberdade humana só se realizava dentro de certas situações, isto é, depara-se com limites (Cf. 231-236).

${ }^{186}$ Cf.Ibid., 228-236.

${ }^{187}$ Cf.Ibid., 236-243.
} 
explicado pela física e pela química, como também cientificamente não se pode concluir sobre o enigma do espírito do homem. ${ }^{188}$

\section{3}

\section{A religião na atualidade}

As Igrejas cristãs, de uma forma geral, perderam seu monopólio sobre a religião. $\mathrm{O}$ mundo se encontra diante de uma nova constelação de valores que colocam as Igrejas diante de enormes problemas advindos da secularização, da pluralização e da globalização. Enquanto isso, as grandes religiões se fazem presentes em diversos países e com certa constância nos veículos de comunicação. Este fenômeno colabora para o que Küng denomina de "religiosidade errática", configurada por um ajuntamento composto de religiosidades que se estabelece de forma arbitrária em qualquer lugar, recebendo a adesão fortemente influenciada por fatores subjetivos. ${ }^{189}$

Küng compreende que a atual crise do cristianismo na Europa, é resultado de fatores complexos. As dificuldades geradas pela não aceitação completa da modernidade por parte da Igreja Católica, e em parte também pela Igreja protestante, favorecendo ressentimento, desconfiança e afastamento, por parte de diversos segmentos da sociedade. No entanto, para Küng, hoje não existem tantos ressentimentos contra a religião como em períodos anteriores. Sendo uma ótima oportunidade para reavivar a religião, que hoje é ignorada pelo esquecimento das dimensões mais profundas do ser humano e pela concentração da sociedade no mundo material. Mesmo assim, hoje, não se despreza a religiosidade em si, pelo menos até que ela não se apresente de forma reacionária e agressiva. A religião não está relegada ao silêncio, mas o fato é que frequentemente se apresenta de uma forma que para muitos não é interessante ou provocando reações contrárias. $^{190}$

Küng reconhece que o confessionalismo é um grande empecilho para novas adesões religiosas às Igrejas cristãs, principalmente no caso da Igreja católica. A sociedade atual não se prende em questões da rigorosidade doutrinária e da Tradição. Estas são questões a serem superadas. No entanto, isso não significa

\footnotetext{
${ }^{188}$ Cf.Ibid., 243-260.

${ }^{189}$ Cf. KÜNG, Hans. Para que um ethos mundial?, op. cit., p. 11-12.

${ }^{190}$ Cf. Ibid., p. 12-15.
} 
aderir certa falta de diferenciação doutrinária, uma tarefa fundamental da teologia. Deve-se destacar aquilo que une os cristãos e não o que os separa. Sendo necessária para esta tarefa a arte da diferenciação doutrinária. Tal diferenciação para ser clara e lúcida, deve exigir o que Hegel chamava de "trabalho conceitual". A Igreja católica em sua postura deveria trilhar um caminho intermediário entre o liberalismo e o rigorismo. Para buscar este caminho, acredita que o perfil do papa capaz de promover esta mudança deve possuir raízes no Evangelho e para o mundo. Sendo um caminho promissor para o futuro do catolicismo com o mundo, a possibilidade de avaliar onde se encontra, em sua estrutura interna e no seu relacionamento com a sociedade, a necessidade de contextualização ${ }^{191}$

Reconhecendo que as divisões existentes no cristianismo, em várias confissões e vertentes, é um fator negativo para sua aspiração do projeto de um ethos mundial para as religiões. Afirma que os lentos processos ecumênicos entre protestantes e católicos na Alemanha, ou entre Roma e os protestantes, não são devido a questões teológicas, mas a uma questão de poder, sendo mais uma questão de vontade política que de reflexão teológica. ${ }^{192}$

Sobre o fato do cristianismo estar a frente na discussão e no diálogo com outras religiões, apresenta como preponderante as mudanças de paradigmas por qual o cristianismo passou no decorrer da Reforma e da Modernidade. E sob este aspecto o islamismo ainda carece de profundas transformações, estando ainda em aberto à exegese e hermenêutica do Corão, como também deveria ser reestudada sob um ângulo crítico pelos maometanos a história das conquistas islâmicas. Sendo a obstrução da aplicação de uma exegese utilizando o método históricocrítico ao Corão, uma realidade que impede profundas transformações no islamismo. No entanto, Küng acredita na possibilidade de mudanças pelo aumento de intelectuais nas fileiras do islamismo, podendo transformar-se em importantes interlocutores para as mudanças necessárias, para que um ethos mundial seja aceito pelo Islã e para que seja possível a tolerância religiosa e a solução para a violência no islamismo. ${ }^{193}$ Küng defende uma religiosidade da dignidade humana como fundamento para todas as religiões.

\footnotetext{
${ }^{191}$ Cf. Ibid., p. 15-17; 33; 49; 53.

${ }^{192}$ Cf. Ibid., p. 35-36; 55.

${ }^{193}$ Cf. Ibid., p. 57-61.
} 


\section{4 \\ 0 ethos fundamental}

De onde vêm determinados valores éticos, determinados padrões e normas, constituindo-se como uma das características dos seres humanos? Küng alega que o comportamento ético esta radicado na natureza biológica, fruto da evolução humana, tendo em vista a própria sobrevivência, podendo ser encontrado um comportamento cooperativo de origem genética, sobre tudo entre parentes e membros de um mesmo grupo social. No entanto, vale ressaltar, os fatores socioculturais que nas diferentes sociedades desempenham um papel crucial para o comportamento ético. ${ }^{194}$

Por tal complexidade, uma interpretação, apenas biológico-mecanicista, não se constitui como suficiente para explicar a origem dos valores éticos, mesmo que algumas capacidades necessitem da interação social para serem aprendidas. Do mesmo modo, a evolução do pensamento estratégico colaborou para o comportamento social humano. O processo sociodinâmico e sua evolução permitiu o estabelecimento de normas, valores e visões éticas concretas. ${ }^{195}$

Como não existe povo sem religião, igualmente não existe povo sem ética. O reconhecimento e aprovação de algumas normas, já encontrada em culturas tribais, levaram as mesmas a universalização: a) reciprocidade da justiça e da generosidade; b) normas para o respeito à vida; c) regras de convivência entre os sexos. Nomeando estes acordos como "ethos fundamental", entendendo que o mesmo estabelece o núcleo comum da humanidade, ou seja, um ethos mundial. Este ethos encontra seu fundamento, sincronicamente, nas normas básicas comuns às diversas religiões e culturas em nossa era. Diacronicamente, se fundamenta nas normas básicas das culturas tribais pré-históricas. Apesar de nem toda norma pertencer a um ethos original, pode-se afirmar que se constitui como continuidade e desdobramento que tem como base um "ethos primordial" biológico-evolutivo comprovado temporalmente. ${ }^{196}$ No entanto, Küng acredita ser possível uma ética sem Deus, alegando que muitos agnósticos e ateus possuem uma postura ética melhor que muitos crentes. O risco para toda ética pode ser configurado pelo o fundamentalismo crente ou ateu.

\footnotetext{
${ }^{194}$ Cf. KÜNG, Hans. O princípio de todas as coisas, op. cit., p. 260-261.

${ }^{195}$ Cf. Ibid., p. 261.

${ }^{196}$ Cf. Ibid., p. 262-263.
} 


\section{5 \\ Um olhar para o ateísmo moderno}

Küng salienta que a Revolução Francesa fez emergir diversas formas de ateísmo que se encontram na atualidade: o humanista, o político e o científico. ${ }^{197}$ Hoje, mais do que nunca o ateísmo pede à fé em Deus uma explicação, principalmente pelo fato do ateísmo ter se tornado, recentemente, um fenômeno de massas. ${ }^{198}$ No entanto, os vestígios destas formas foram provocados pelas próprias formulações e comportamento cristão.

Nas questões morais, o principal motivo para o surgimento do ateísmo humanista foram os modelos que, em nome do amor cristão, valorizavam a ascese em detrimento do ser humano. Somando-se a doutrina da predestinação e o proselitismo; a desqualificação da corporeidade, sexualidade, alegria mundana, diversão e do teatro, encontradas no jansenismo e na maioria dos puritanos e petistas protestantes. Muitos humanistas no curso da Modernidade espantaram-se com o cristianismo e a fé em Deus, que apenas parecia possível em detrimento dos seres humanos, sendo esta postura nítida em Feuerbach e Nietzsche. Porém, na realidade, os humanistas se confrontaram com modelos que em quase nada se identificam com a vida e ensinamentos de Jesus de Nazaré. ${ }^{199}$

Nas questões políticas, o principal motivo para o surgimento do ateísmo político foi a falha do cristianismo, incluindo a Igreja Católica, no que diz respeito aos problemas sociopolíticos, esquecendo-se de que o amor ao próximo e comprometimento político são lados da mesma moeda. Problemas que não foram confrontados em sua raiz pela Igreja. A aliança da fé em Deus espiritualizada e individualizada com as pretensões políticas absolutistas do poder real contribuiu para o descrédito da fé em Deus, principalmente para a burguesia progressista da França. Voltava-se contra a fé em Deus por estar a serviço dos monarcas e dos

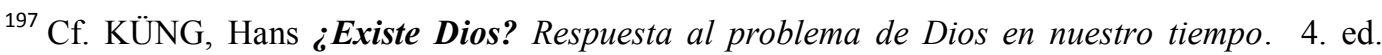
Madrid: Ediciones Cristandad. 1979, (T.N), p. 125-126. Küng aponta à importância do legado de Descartes e Pascal para esclarecer a questão de fé e razão na modernidade. Abordando tanto os equívocos do "penso, logo existo" de Descartes, quanto alguns descompassos "do creio, logo existo" de Pascal em relação ao ensino neotestamentário, devido à tradição agostiniano-reformista, como formas para o desencadeamento do confronto (Cf. Ibid., 25-140). Sobre a postura de Pascal, não seria corretor dizer que ele matinha uma hostilidade aberta à ciência: "mais precisamente, seria melhor dizer que até o último momento de sua vida, viveu em um constante conflito interno, nunca resolvido, entre ciência e religião, o espírito de pesquisa e amor dos Deus" (Ibid., p. 135).

${ }^{198}$ Cf. Ibid., p. 20. Para o autor uma resposta convincente só é possível intercambiando o material acumulado em toda Idade Moderna.

${ }^{199}$ Cf. Ibid., p. 128.
} 
representantes da Igreja, como meio de impedir a difusão da "luz da razão" e manter as pessoas em sua menor idade, isto é, na ignorância e cativa ao ancien régime. Em 1793, o Deus cristão é deposto e proclama-se como deusa a razão ateia. Pela primeira vez no mundo o ateísmo se torna uma proposta política. Emergindo assim, o ateísmo político em suas diferentes formas, o ateísmo liberal burguês e o proletário-socialista. ${ }^{200}$ Fique evidente que, pelo lado cristão, foram negligenciadas e desentendidas por completo as implicações sociais da pregação, o comportamento e destino de Jesus como potência ética e de relevância social da mensagem cristã. ${ }^{201}$

Nas questões científicas, o principal motivo para a provocação do surgimento do ateísmo científico foi a desqualificação, feita pelos proponentes da fé cristã, da razão e liberdade humana no exercício da ciência e da filosofia para compreensão do homem, do mundo e de Deus. Desta forma, entende-se ser necessário desqualificar o próprio ser humano para se crer em Deus. E que apenas a Revelação e a fé seriam possíveis para perscrutar verdadeiramente a existência. Desta confrontação, o resultado é a desqualificação da própria fé cristã para emitir juízo sobre o mundo. Sendo considerada ingênua, retrógrada e insuficiente para o pensamento do homem moderno. A não superação do paradigma bíblico sobre a criação e a natureza humana, recebida da tradição agostiniana e presente nos reformistas, nos jansenistas e entre teólogos protestantes, aumenta cada vez mais a distância entre ciência e religião e entre fé e razão. No entanto, esta hostilidade à filosofia, a razão e a ciência não é necessária à fé cristã. ${ }^{202}$

Estes combates exigiram da fé cristã uma compreensão crítica da Bíblia a luz dos novos descobrimentos físico, astronômicos e médicos. Quando a compreensão adequada da realidade não era atingida pela teologia cristã, o ateísmo científico assinalava, com toda lógica, que não necessitava de Deus para explicar o mundo físico, nem para conduzir a vida moral dos seres humanos. ${ }^{203}$

Outra questão para a promoção do ateísmo científico foi dualismo estabelecido por Descartes entre "espírito e matéria", entre um "Deus superior e a máquina do mundo" que, consequentemente, dividiu a filosofia entre idealismo e

\footnotetext{
${ }^{200}$ Cf. Ibid., p. 130-131.

${ }^{201}$ Cf. Ibid., p. 130-131.

${ }^{202}$ Cf. Ibid., p. 132-135.

${ }^{203}$ Cf. Ibid., p. 135-137.
} 
materialismo. No entanto, o mundo tinha que ser explicado por um princípio unitário $^{204}$. Na busca deste princípio, sendo materialismo utilizado pela primeira vez com Robert Boyler, fundador da química científica, que supera a doutrina dos quatro elementos de Aristóteles, no entanto, defende uma perspectiva cristã. As consequências de um materialismo ateu emergem a partir de Julien Offray LaMettrie - tendo culminância na tradição de livre pensamento anglo-francês Jean Bodin, Herbert von Cherbury e Collins Anthony, que passa por Thomas Hobbes, Bayle Pierre e Voltaire, atingindo os enciclopedistas. Esta nova forma de compreender o mundo rechaça o Deus da Patrística e de Jesus Cristo, como também o Deus dos deístas, isto é, o Deus dos filósofos e dos sábios. ${ }^{205}$

A obra de LaMettrie, $O$ homem máquina, 1748, aplica ao homem a concepção mecanicista cartesiana dos animais como complexas máquinas. Sendo o pensamento do homem, incluindo toda sua psique, resultado de processos corporais que só podem ser explicados a partir do mecanismo do sistema nervoso. Assim, tanto a consciência dentro do ser, como o espírito dentro dos copos se explicam a partir deste mesmo ser, do corpóreo, da matéria. Como resultado a religião perde a relevância de antes, podendo ser considerada irrelevante. ${ }^{206}$

Após a morte de LaMettrie, a linha materialista atéia é continuada por P.H. von Holbach, residindo em Paris, vinte anos antes da grande Revolução, publica sob pseudônimo a dogmática geral do ateísmo materialista, Sistema da natureza e as leis gerais do mundo físico e moral, 1770, declarando nesta obra a identidade entre matéria e espírito, entre física e moral, e a nocividade da religião, devendo os sacerdotes serem substituídos por médicos. Afirmando que a sobrevivência da alma após a morte seria tão absurdo como se um relógio quebrado em mil pedaços pudesse seguir marcando as horas. ${ }^{207}$

Os resultados da ciência mecânica davam enorme vantagem aos argumentos do materialismo ateu e a razão. A fé em Deus torna-se cada vez mais desnecessária diante de uma ciência que se aprofundava no conhecimento da matéria e suas ilimitadas possibilidades. Principalmente quando P. S. Laplace, o

\footnotetext{
${ }^{204}$ Enquanto a direita cartesiana pretende explicar o todo partindo da ideia divina eterna - desde Malebranche e Spinoza, Schelling e Hegel -, a direita busca explicar partindo da matéria divina eterna.

${ }^{205}$ Cf. Ibid., p. 137-138.

${ }^{206}$ Cf. Ibid., p. 139.

${ }^{207}$ Cf. Ibid., p. 139.
} 
Newton da França, em seu Tratado de mecânica celeste, volume I-V, 1805-1825, explica na base das correções dos próprios planetas, as irregularidades208 de Saturno e Júpiter. Laplace alega não necessitar de Deus como hipótese para apresentar explicações sobre o mundo material. ${ }^{209}$

Desta compreensão, todo sistema solar resulta mecanicamente estável sendo o universo autodirigido, autopersistente e por tempo ilimitado. Mesmo contra a oposição da Igreja, da teologia, do Estado e de todos que eram fiéis à autoridade, a ciência da natureza, com seu método, se torna possível sem Deus, que passa a não ter papel nenhum a desempenhar. Com a grande Revolução política, a ciência mecanicista não mais será prejudicada por uma declaração de fé, e assim dá-se a supressão de Deus. A religião, a partir daqui, não é mais questão científica, mas privada. No entanto, para muitos, até na questão privada a ciência deveria substituir a religião. ${ }^{210}$

Imediatamente pode ser percebido, segundo a explanação de Küng, que o confronto não se dá entre a essência da ciência e religião, nem entre razão e fé, mas entre as versões equivocadas das mesmas, quando extrapolam seus próprios limites intrínsecos, isto é, a própria competência para explicar as questões fundamentais sobre os seres humanos e o mundo.

Existe Deus? Para Hans Küng, a resposta é sim. Sendo razoável que o homem contemporâneo acredite em Deus, mesmo no Deus cristão, mais facilmente que há décadas ou séculos atrás. Depois de muitas crises, muitas coisas se tornaram claras e muitas dificuldades contra a fé em Deus têm sido eliminadas, mesmo que alguns não tenham a seguinte consciência:

Hoje não é necessário ser contra Deus pelo fato de estar a favor do geocentrismo e da evolução, da democracia e da ciência, do liberalismo ou socialismo. Não, hoje, ao contrário, é possível estar a favor da verdadeira liberdade, igualdade e fraternidade, a favor da humanidade, liberdade e justiça social, a favor da democracia humana e do progresso científico controlado, precisamente porque se crer em Deus. ${ }^{211}$

Há algum tempo, um prêmio NobeI inglês respondeu que não acreditava em Deus por ser cientista. Porém, Küng alega que seus escritos, sobre esta questão,

\footnotetext{
${ }^{208}$ O que Newton atribuía a Deus.

${ }^{209}$ Cf. Ibid., p. 139.

${ }^{210}$ Cf. Ibid., p. 139-140.

${ }^{211}$ Ibid., p. 21
} 
são impulsionados pela esperança de uma nova era em que a resposta deve ser oposta, isto é, acreditar em Deus justamente por ser cientista. ${ }^{212}$

Para Küng, não é possível um mundo ateu. Apesar de guerras poderem ser causadas por compreensão inadequada da religião, e por utilização da mesma por motivos ideológicos, políticos e econômicos, a religião também pode promover entendimento, reconciliação e paz. A fé é necessária, mas não pode ser imposta, e deve ser acolhida e apresentada de forma que possa haver raciocínio e reflexão sobre o seu sentido, caso contrário, o fundamentalismo será estabelecido. Mesmo que não haja provas irrefutáveis da existência de Deus, existem bons motivos para aceitar a fé em Deus como sábia. A fé não é racional e nem racionalista. Podendo atingir todos os níveis culturais e tocar a esfera emocional dos seres humanos. Não se baseando em conceitos aceitos da sua contemporaneidade, mas fundamentando-se no que se compreende como escrituras sagradas e nas tradições, possibilitando a sua transmissão e perpetuação através do tempo, sobrevivendo mesmo diante dos mais ferrenhos ataques.

O sofrimento pode afastar muitas pessoas da fé em Deus? Küng salienta que o sofrimento não é prova da inexistência de Deus. No entanto, enfatiza, que a dor pode também suscitar a pergunta pela existência de Deus. Alega que a questão do sofrimento não pode ser explicada racionalmente, afirmando que nem meu o ateu pode dá-lhe resposta satisfatória. Ao mesmo tempo acredita que exista uma realidade capaz de acolher e de resgatar todo sofrimento do mundo.

Sobre os neoateísta, alega que são fundamentalistas ateus. E sobre um dos seus representantes mais conhecido da atualidade, Richard Dawkins e seus seguidores, Küng afirma que não podem ser comparados aos grandes ateus da humanidade: Marx, Feuerbach, Nietzsche e Freud. Um dos motivos para esta alegação é o fato dele simplesmente ignorar todo literatura filosófico-teológica e substituir a crítica fundamentada por uma ironia fácil, desconsiderando que a teologia é uma ciência que fez enormes progressos ao logo dos séculos. ${ }^{213}$

\footnotetext{
${ }^{212}$ Cf. Ibid., p. 21.

${ }^{213} \mathrm{Cf}$. KÜNG, Hans. O princípio de todas as coisas, op. cit., p. 75-76.
} 


\section{6}

\section{A escatologia em Hans Küng}

O que é escatologia? Eschatos (último) e logia (discurso, estudo) designa comumente a doutrina das últimas coisas. Na concepção usual do termo em conformidade com a maioria dos tratados de dogmática, católicos ou protestantes, escatologia significa área da doutrina cristã que se ocupa com o destino final da humanidade e do mundo.

Uma visão mais ampla da escatologia compreende o termo, não como um estudo centrado apenas no desfecho da história que hoje transcorre, mas a compreende como o desenrolar de toda a criação, desde seu início, pois toda criação apontaria para plenificação. Nesta visão, a escatologia não se torna apenas um capítulo no final dos tratados da dogmática, mas toda a essência da fé que deposita confiança na benevolência e amor de Deus na vida, e na sua continuidade para vida plena, onde se realizará no encontro glorioso com Jesus Cristo. ${ }^{214}$

Outras conceituações do termo escatologia se encontram desta perspectiva mais ampla, diferenciando apenas em alguns enfoques. Como a teologia da esperança de Moltmann, onde o enfoque é dado a partir da realidade histórica de Jesus e sua ressurreição. Fundamentando todas as afirmações sobre o futuro na pessoa e na história de Jesus Cristo, e nas consequências deste marco histórico, já no aqui e agora, no desfecho da atual história do mundo e da humanidade. ${ }^{215}$

Esta pesquisa investigará a compreensão escatológica de Hans Küng, abordando o momento derradeiro da existência humana e do universo, utilizando a sua obra ¿Vida Eterna?

\subsection{1}

\section{Morte, eternidade e o céu da fé: sentido e significado}

1. A morte tem sentido? O sentido da vida interpela o homem pela causa primeira e última. Nascimento e morte fazem parte da existência que em seu todo deve ser interpretada. Não importa a forma como ocorra a morte, ela suscitará a

\footnotetext{
${ }^{214} \mathrm{Cf}$. BOFF, Lina. Da esperança à vida plena em Cristo: vivendo as realidades que entrevemos. Juiz de Fora : Editar Editora Associada, 2010, p. 11-39.

${ }^{215}$ Cf. MOLTMANN, Jürgen, op. cit., p. 21-23.
} 
pergunta radical que, pelo seu próprio sentido, inegavelmente, mantém um relacionamento íntimo com o sentido da vida. ${ }^{216}$

Para Küng, deve-se evitar teologicamente toda abordagem que se assemelhe com a exploração do desejo da vida eterna, enquanto não for possível afirmar a realidade da vida eterna de forma coerente. Colhendo dados de investigações das ciências médicas e psiquiátricas que avaliam a questão da morte, hoje, fora do horizonte enrijecido do materialismo e positivismo científico, que estão em fase de superação, e da experiência de moribundos, é possível relacionar e encontrar dados que corroboram para o discurso de uma vida após a morte. Como julgar todas estas informações por uma perspectiva teológica? ${ }^{217}$

Não seria prudente fundamentar uma certeza na vida após a morte em dados apenas com fundo psicológicos. Não são dados seguros, devido à existência de diversas razões para se acreditar na vida após a morte, desde crenças e até sugestão. $^{218}$

Para Küng, os casos de experiência de morte, por suas próprias ambiguidades, não devem ser negados, mas sim interpretados. Logo, não se pode aceitar esta explicação como final e única. Podem-se ter outras, porém, seria grave, de antemão, desconsiderar a possibilidade de explicação pela compreensão científico-médica e, eventualmente, psicológica destes fenômenos. Neste sentido, tais fenômenos não se relacionariam com a dimensão suprassensível no além, com a vida após a morte. Esta questão reclama uma classificação urgente do que se entende exatamente por morte. ${ }^{219}$

Ao investigar as obras referentes ao quadro médico que definem a morte, Küng observou que definem esta realidade como morte clínica e subsequente morte biológica, caracterizada como o cessar de todos os sinais vitais, a impossibilidade de reanimação e de aproveitamento de órgãos. No entanto, Küng discorda desta concepção, por muitos dados demonstrarem que tal definição não pode ser corroborada com os casos de mortes clínicas e biológicas confirmadas, onde, subitamente, o suposto morto volta à vida. Em outros termos: uma experiência de iminência de morte não é experiência de morte. Logo, estava

\footnotetext{
${ }^{216}$ Cf. KÜNG, Hans $\boldsymbol{\text { ¿Vida Eterna }}$ ? 4. ed. Madrid: Editorial Trotta, S.A, 2007, p. 70.

${ }^{217}$ Cf. Ibid., p .23-33.

${ }^{218}$ Ibid., p. 37-38.

${ }^{219}$ Cf. Ibid., p. 38-43.
} 
falsamente morto. Então, todos os casos registrados na literatura médica, onde o morto volta à vida, não se tratam de uma fase da morte, mais sim de uma fase da vida. São experiências de pessoas que se aproximaram de uma morte real, que erroneamente haviam crido morrer, mas não morreram. Chegando a estar no limiar da morte, mas nunca a transpassaram. ${ }^{220}$

Para Küng, é um dever de veracidade teológica responder taxativamente que tais experiências nada significam para uma vida após a morte. Nada provam. São minutos antes de morrer, minutos de transição, portanto, nada decidem sobre a questão para onde vai o moribundo. Apesar de não provarem a vida eterna, tais experiências possuem algumas contribuições positivas para aqueles que as vivenciaram e para aqueles que por elas perguntam. Porém, a questão continua aberta: a vida eterna seria uma piedosa ficção ou projeção dos religiosos, ou uma realidade para todos os seres humanos? Por que não posso pensar que há vida após a morte? E por que apesar dos argumentos da projeção, desejo, ilusão a verdade não poderia ser o contrário? Küng afirma: as teorias e interpretações de Feuerbach, Marx, Freud, e toda negação do ateísmo da vida eterna podem voltarse contra suas próprias teses. Então como sair deste embate ${ }^{221}$ Küng acredita ser necessário formular a pergunta pelo sentido da morte. ${ }^{222}$

Martin Hiddegger, Jean Paul Sartre e Karl Jasper, se esforçaram para apresentar a morte como parte integrante da existência humana. Küng apresenta um balanço provisório destas três posturas filosóficas: a) interpretação filosófica da morte parece difícil, se não impossível. Mesmo abordando a questão da morte com seriedade, as posturas não são apenas diferentes, mas contraditórias; b) a teologia não deve colocá-las em confronto e escolher a mais afim; c) a teologia deverá equilibrá-las para esclarecer a atitude do homem diante da morte. Após este balanço provisório, Küng afirma: a) segue aberta para Heidegger; b) em Jasper, é resolvido positivamente; c) Sartre, definitivamente tem uma resposta negativa. ${ }^{223}$ É interessante observar a seguinte constatação sobre as discussões abordadas:

\footnotetext{
${ }^{220}$ Cf. Ibid., p. 43-49. Para Küng, nestes casos, não houve realmente a morte, mas o último estágio da vida que não pode ser verificado pelo atual instrumental da ciência. Uma vez que, para o autor, a morte é condição irreversível.

${ }^{221}$ Cf. Ibid., p. 47-49; 51-68.

${ }^{222}$ Cf. Ibid., p. 70.

${ }^{223}$ Cf. Ibid., p. 71-77.
} 
A nenhuma delas se pode recorrer para fundamentar a afirmação da vida eterna: a filosofia devolve a pergunta para a teologia. De modo que, quem diga que a morte, ocasional e fortuita, é absurda, que portanto, significa a destruição do homem inteiro (incluindo o seu espírito, porque este, afinal, está inteiramente ligado ao cérebro e outros órgão) dificilmente pode ser refutado com argumentos racionais. Mas, como é óbvio, tampouco, ele pode demonstrar a sua posição racionalmente. ${ }^{224}$

Diferentemente da análise dos dados médicos, esta questão da vida após a morte não está aberta:

Mas também, como resulta agora da confrontação com os filósofos mais recentes, uma grande escolha. Ou uma coisa ou outra: duas opções fundamentais no que diz respeito ao homem e ao mundo, as duas opções que devem ser executadas humanamente, responsavelmente. ${ }^{225}$

Küng prossegue:

Não devemos fugir de continuar exercitando o pensamento. A teologia não é de antemão mais fácil que a filosofia. Nenhuma opção intelectual deve ser ignorada. Toda palavra sobre a morte sobre o silêncio exige uma resposta. ${ }^{226}$

2. A vida após a morte. Küng enfatiza que em geral as religiões desde a origem da humanidade reclamam uma vida após a morte, ainda que, com diferenças de compreensão. Sobre a reencarnação, alega que não corresponde aos dados do Novo Testamento, e que de maneira nenhuma pode ser demonstrada. Refuta também a posição do eterno retorno de Nietzsche, entre outras. Afirma que o homem, sendo mais do que pura razão, é chamado a tomar uma decisão, mesmo que não demonstrada pela razão, pelo menos deve prestar contas a ela. Esta decisão estar relacionada com a morte e o além da morte, com o sentido do morrer e do viver. Devendo ser considerado nesta decisão: a) que nem tudo é igualmente aceitável; b) nem todas as representações da morte durante a história estão ao mesmo nível; c) nem possuem o mesmo valor. ${ }^{227}$

A tradição judaico-cristão-islâmica, e em particular, especificamente, a mensagem cristã é capaz de decidir sobre as questões aqui abordadas. Mas para decidir, deverá comunicar a sua mensagem informando a evolução e complicações, fraquezas e grandezas da fé cristã na questão da vida eterna.

\footnotetext{
${ }^{224}$ Ibid., p. $77-78$.

${ }^{225}$ Ibid., p. $80-81$.

${ }^{226}$ Ibid., p. 82.

${ }^{227}$ Cf. Ibid., p. 83-103; 107; 124-125.
} 
Devendo considerar que compreensão da vida após a morte passa por uma evolução. O Eclesiastes perpassado pelo ceticismo onde a concepção de vida após a morte não passava de uma sombra no Sheol, difere de Provérbios e do Sirácida que mantinham esperança no futuro. Perto do fim do período do Antigo Testamento, o livro de Daniel $(12,20)$ e 2 Macabeus (cap. 7 e 8 ) pregam a ressurreição dos mortos, o que jamais foi afirmado no Antigo Testamento antes do século II a.C. Após o exílio babilônico, os judeus estavam insatisfeitos com a crença de que a vida termina com o túmulo, à exceção da temporada no Sheol. Neste contexto, Provérbios e Sirácida abrem caminho para o livro de Daniel e 2 Macabeus. Desta forma, o conceito de vida após a morte evoluiu do Antigo Testamento até a apocalíptica judaica, este último, o ambiente no qual Jesus viveu e pregou a sua mensagem. ${ }^{228}$

No entanto, o quem vem depois da morte faz parte deste jogo de sentido e significado. Você crê na vida após a morte? Hoje, esta pergunta parece fora de moda, mas desde as origens da humanidade fora carregada de significado. E o que pode significar esta pergunta hoje? Küng argumenta que o descaso para o sentido da pergunta, nos dias de hoje, está muito relacionada com a desinformação, acrescenta a isso:

O discurso dos teólogos em defesa da vida eterna tem sido de modo geral pouco convincentes, desconectados da realidade, fora as dificuldades dos homens pensantes de hoje diante das contradições da Bíblia no tocante a morte e a ressurreição. O céu e a terra e o fim do mundo e o juízo universal. Por outro lado, os argumentos contra tornaram-se mais sólidos e sugestivos, e seus representantes, com muita verdade em suas perguntas, tem coisas mais importantes a dizer: Que coisa é a vida eterna senão a projeção de um desejo (Feuerbach), vã esperança para os oprimidos (Marx), negação do eterno retorno (Nietzsche), regressão irreal própria de uma imaturidade psíquica (Freud)...? $?^{229}$

Sobre as questões após a morte, diversos filósofos existencialistas e de orientação neomarxista, já começaram a discutir de forma mais diferenciadas e o eco das respostas se faz presente. Independente de como é abordada a questão, Küng entende que existe em todas as partes um potencial de esperança e uma orientação:

\footnotetext{
${ }^{228}$ Cf. Ibid., p. 125; 138-157.

${ }^{229}$ Ibid., p. 11.
} 
De forma que em nosso mundo, impregnado de positivismo e materialismo, gradualmente está se espalhando a convicção de que a questão da vida eterna não pode ser resolvida com meras fórmulas como "desejo", "ópio", "ressentimento", "ilusão". ${ }^{230}$

Hoje, vive-se em meio a uma grande crise de orientação social. Novos problemas, novos medos e nostalgias. Busca-se um sentido para vida. A religião apesar de todas as críticas volta a ser atual. O deus "progresso", a crença numa vida sempre melhor por obra da ciência e da tecnologia, a crença na revolução e no socialismo parecem minadas por sérias dúvidas. Até a nova geração pergunta pelo sentido da vida. A medicina e a ciência que no último século colaboraram para destruir a fé na imortalidade, hoje tem quebrado o tabu da morte, e com suas investigações vem dando nova atualidade a pergunta pela morte e a vida após a morte. No entanto, talvez ainda mais urgentes sejam problemas de outros tipos: como uma morte digna, ajuda aos moribundos, progresso em direção a um reino de justiça e de alternativa de outra perspectiva de vida. ${ }^{231}$

Küng não pretende um tratado de escatologia, mas responder as questões contemporâneas sobre a questão do fim da vida e a consumação de todas as coisas, e para isso, dialoga com diversas correntes filosóficas e religiosas, valendo-se do ponto de vista da investigação teológica atual, sem se perder nestas, e despreocupado com as modas teológicas. ${ }^{232}$

Após essas considerações, alega que vida após a morte não deve ser apenas afirmada, como fazem muitos teólogos, judeus, mulçumanos e cristãos, que definem a questão dizendo que é verdade, pois está escrito desde o início onde acreditam ser a Revelação de Deus. Independentemente do está "escrito", a crença na vida após a morte requer um julgamento teológico e exegético, onde se possa perguntar por questões essenciais: não estariam baseados em pressupostos infundados? Não seria a palavra Deus uma superestrutura teológica fruto da projeção humana? Não seria o que os homens dizem de si? As escritas não seriam projeções das aspirações e desejos humanos ${ }^{233}$

\footnotetext{
${ }^{230}$ Ibid., p. 12.

${ }^{231}$ Cf. Ibid., p. 12-13.

${ }^{232}$ Cf. Ibid., p. 13-14.

${ }^{233}$ Cf. Ibid., p. 129.
} 
Küng afirma que sobre as questões referentes a vida e a morte, não é a decisão da razão pura que deve prevalecer, mas todo o homem. No entanto, devese tomar uma decisão racionalmente justificada. ${ }^{234}$ E continua sobre esta questão:

Daqui resulta que para teologia não é lícito evitar a necessidade de estabelecer a fé na eternidade. Se a razão se vê neste caso obrigada a abdicar, se for necessário um sacrificium intellectus, tal fé seria por princípio não crível, insensata, mais ainda, não humana. Precisamente a fé que respeita as últimas coisas deve ser comunicável, dialogante; só assim poderá dialogar com qualquer homem (cristão ou não) sobre a morte, sobrevivência, a nova vida. Em todo diálogo devem se incluídas as experiências do respectivo interlocutor. Uma decisão responsável de fé, portanto, pressupões uma fé igualmente responsável, não cega, na vida eterna: para que assim o homem não se veja violentado intelectualmente, mas se convença por razões. ${ }^{235}$

Os filósofos, desde Platão, trabalharam em prol de argumentarem a favor da imortalidade da alma, argumentação que permanece até Kant. Este, por sua vez, argumentara que, embora a existência de Deus e a imortalidade da alma não pudessem ser comprovadas, a imortalidade da alma era um postulado da razão, precondição para o comportamento ético dos seres humanos. Küng continua a sua exposição alegando que, apesar de não demonstrável e de todos os argumentos contrários, a fé na eternidade é bem fundamentada na experiência humana. E esta experiência, tendo como base a mensagem bíblica, levando a uma justificação razoável para a crença na vida eterna. Realidade que se não existisse, para muitos, a vida pareceria sem sentido. Assim, a vida eterna é uma questão de confiança, confia-se e compromete-se com fé na vida além da morte, com a certeza de que toda a vida humana não terminará num vazio, e nossa esperança de um sentido absoluto se realizará. ${ }^{236}$

3. A eternidade: o céu da fé. Diante dos diversos modelos representativos do Novo Testamento, como dizer o que é vida eterna? Küng descreve, no contexto do material apresentado, a vida eterna sobre dois pontos de vista, um negativo e um positivo.

Na concepção negativa. Não é um retorno a esta vida espaço-temporal: não é retomar o próprio corpo, conforme a ressurreição dos mortos na literatura antiga, mas a morte é ultrapassada, superada definitivamente. Na concepção do Novo

\footnotetext{
${ }^{234}$ Cf. Ibid., p. 231-232.

${ }^{235}$ Ibid., p. 130.

${ }^{236}$ Cf. Ibid., p. 130-138.
} 
Testamento, o Ressuscitado ultrapassa a última fronteira que é a morte,entrando numa vida completamente distinta, celestial, na vida de Deus, formulada e representada de maneiras diversas. Não é uma continuação desta vida espaçotemporal: a eternidade não tem um antes e um depois. Indica uma vida totalmente nova que rompe as categorias de espaço e tempo e se desenrola no âmbito invisível, incompreensível de Deus. Significa estar definitivamente junto de Deus e ter assim a vida definitiva. ${ }^{237}$

$\mathrm{Na}$ concepção positiva. É um pressuposto da realidade último-primeira absoluta: se não quer-se falar em linguagem figurada temos que ver a ressuscitação (ressurreição) e a elevação (rapto, ascensão, glorificação) como um só e idêntico acontecimento. Um acontecimento inescrutável e secreto de Deus relacionado com a morte. A mensagem Pascal em todas as suas variantes afirma: Jesus ao morrer não foi parar no nada. Foi recebido em Deus. Na morte e pela morte passou à essa primeira e última realidade, que chamamos Deus. $\mathrm{O}$ homem ao morrer está liberado das condições que o rodeiam e o determina, isto é, rompe com as relações humanas e com as coisas, está agora em relação com Deus. A morte dá ao homem inteiro e indiviso, um novo e eterno futuro: a) não um novo futuro em nosso espaço e tempo (aqui, agora); b) tampouco um novo futuro num espaço e tempo distinto (do outro lado, lá em cima, fora deste mundo); c) mas um futuro novo, completamente distinto: ${ }^{238}$

O último itinerário do homem, o decisivo, e completamente outro, não conduz não como os clinicamente mortos - outra vez a vida cotidiana, ou - como os cosmonautas - para fora, o universo, além do universo. Esse itinerário é (para continuar falando metaforicamente) uma despedida, um retiro para dentro, como uma parada, uma entrada no mais profundo e original sentido do mundo e do homem, no segredo inefável da nossa realidade: uma chegada da morte para vida, do visível ao invisível, da escuridão mortal a luz eterna de Deus. Assim , como, não uma intervenção arbitrária da natureza as leis da natureza, mas uma acolhida nesse mesmo ponto da natureza, seguindo suas próprias leis, chegado a seu fim. ${ }^{239}$

Esta dimensão, os cristãos chamam de céu da fé, que não deve ser descrito como um além-supramundano, no sentido físico-espacial. $\mathrm{O}$ céu da fé não é um além extramundano, não é um céu metafísico. Não é um céu infinito em tempo e espaço, como o da ciência natural. Deus não está em sentido espiritual ou

\footnotetext{
${ }^{237}$ Cf. Ibid., p. 190-191.

${ }^{238}$ Cf. Ibid., p. 192-193.

${ }^{239}$ Ibid., p. 193.
} 
metafísico fora do mundo em um além extramundano. Os cristãos creem que Deus esta no mundo:

O céu da fé não é um lugar, mas um modo de ser; o Deus infinito não é localizável no espaço ou circunscrito pelo tempo. Se , portanto se trata do céu de Deus, significa que se trata desse "domínio" invisível de "âmbito de vida" de Deus "Pai", para indicar que o céu físico, com sua magnitude, claridade e transparência, não pode servir mais do que símbolo. O céu da fé não é outra coisa que o âmbito escondido, invisível e inapreensível de Deus, que não está removido da terra, mas, pelo contrário, aperfeiçoando todas as coisas para o bem, nos faz participar da soberania e o reinado de Deus. ${ }^{240}$

Assim, pode-se coerentemente, apresentar a fé cristã para fundamentar o sentido da vida e o significado da morte, não apenas como um convite para uma orientação fundamental, para o aqui e agora, mas em sua integralidade que está intrinsecamente ligada e inseparável de sua reserva de sentido escatológico.

\subsection{2}

\section{As representações bíblicas científicas do fim}

1. A linguagem utilizada pela Bíblia. Ao mesmo que não podem ser tomadas literalmente, apontam para uma consumação final de todas as coisas. Esta realidade possui sua dificuldade de ser desenvolvida pelo discurso científico e filosófico. Porém, a teologia pode com sua concepção da unidade da criação, a escatologia elaborada sobre a mensagem bíblica, possui possibilidade de fundamentar os horizontes de sentido e valor sobre esta consumação. No entanto, nada mais e nada menos. Logo, as imagens e narrativas bíblicas apontando um julgamento final, devem ser entendidas como algo a dizer a respeito do destino da dimensão cósmica e o destino do ser humano. Estas imagens não podem ser descartadas, pois a história da humanidade aponta para a exigência de uma explanação final e definitiva. Nesta compreensão, o homem é chamado a responder questões referentes ao sentido último de sua vida, e o que fez com sua responsabilidade e liberdade. ${ }^{241}$

A significação das imagens da nova terra, no Antigo Testamento ${ }^{242}$, como uma terra fisicamente propícia aos seres humanos que vivem com novo coração e novo espírito em felicidade e amor. E as imagens do Novo Testamento de

\footnotetext{
${ }^{240}$ Ibid., p. 242

${ }^{241}$ Cf. Ibid., p. 339-346.

${ }^{242}$ Cf. Isaías 11,6-9; 65, 17s; Jeremias 31,31-34; Ezequiel 36,26ss.
} 
banquete, casamento, água viva, árvore da vida, nova Jerusalém, indicando comunidade, amor, claridade, plenitude, beleza e harmonia, precisam de uma significação que permita uma compreensão integral. Olhando estas imagens à luz da ressurreição de Jesus, Küng declara ser possível compreender que a consumação do homem e do mundo se trata de um novo viver na dimensão invisível de Deus, além da nossa dimensão de espaço e tempo. ${ }^{243}$

2. O futuro da humanidade e do universo. A teologia quanto a ciência se ocupam com esta questão. Os astrofísicos em sua maioria concordam que o universo não é estável, imutável ou eterno, não sendo possível admitir a hipótese de um "big bang" seguido de expansão, contração e um "big crunch" formando um novo mundo e novas leis naturais. Hoje, os astrofísicos se inclinam com enorme precisão para a hipótese da expansão continuada que dará origem a um colapso cósmico que culminará, pelo frio gerado no universo, em morte, silêncio, noite absoluta. No entanto, muito antes disto, os cientistas descrevem que, daqui a cerca de 5 bilhões de anos, ocorrerá a expansão do sol em uma gigante vermelha que engolirá a terra. Porém, o real perigo é o fim do mundo como fim da humanidade, provocado pelo próprio ser humano gerando degradação da natureza, por guerras e por terrorismo. ${ }^{244}$

Küng esclarece que, uma compreensão adequada das revelações bíblicas não deve levar em consideração a literalidade dos textos num prognóstico do fim do mundo, mas deve ser considerado como uma linguagem metafórica e poética. São representações e compreensões da época em que foram escritas. Estas revelações não contêm com exatidão o que acontecerá no fim de todas as coisas, pois tanto o início absoluto quanto as últimas coisas não são acessíveis à experiência direta. A afirmação bíblica fundamental do fim é um testemunho de fé, significando que no final da história do mundo encontra-se Deus, o Alfa e o Ômega de eternidade em eternidade. $^{245}$

\footnotetext{
${ }^{243}$ Cf. KÜNG, Hans. ¿Vida Eterna ? op. cit., p. 356-357.

${ }^{244} \mathrm{Cf}$. O princípio de todas as coisas. op. cit., p. 269-274.

${ }^{245}$ Cf. Ibid., p. 274-279.
} 


\subsection{3 \\ O destino da alma}

Para Küng, a compreensão de purgatório é um processo, onde o que verdadeiramente purifica é o encontro com Deus que também julga, liberta, salva e aperfeiçoa no poder de sua graça. O morrer é entrar na dimensão incognoscível de Deus. Onde o espaço-tempo está eliminado para sempre, não sendo possível elucidar nada, não só sobre o lugar e tempo, mas também sobre o modo e maneira deste aperfeiçoamento purificador-salvador. ${ }^{246}$

Como Küng compreende a relação alma-espírito quando ocorre a morte? Discorda da posição dos teólogos católicos e protestantes que tentam fundamentar, teologicamente, uma fase intermediária da alma sem o corpo entre a morte individual e o juízo final. Küng alega que esta postura não coaduna com a Escritura e os conhecimentos psicológicos modernos, e corre o risco de cair num pensamento ultrapassado, já superado, hoje, pela teologia, filosofia e a ciência natural. Devido a concepção do homem indiviso, não concorda com a doutrina estado intermediário. ${ }^{247} \mathrm{O}$ assunto é decidido com a seguinte consideração:

Pois o homem morre em sua totalidade, com corpo e alma, como unidade psicossomática. Mas precisamente este morrer não significa aniquilação total ("morte total" como "annihilatio" e, na melhor das hipóteses, como a sobrevivência na "memória" de Deus ou dos homens). ${ }^{248}$

Sobre o Inferno, como um local de tormento ${ }^{249}$ do outro lado da vida, Küng cita que as primeiras confissões de fé, católicas ou protestantes afirmam a realidade do tormento eterno. Com relação à duração do inferno, menciona que o Credo Atanasiano afirma que o fogo eterno é de fato eterno, igualmente o IV Concílio de Latrão, 1215, o Concílio de Florença, 1442, afirmaram e enfatizaram esta doutrina. As Afirmações da multidão de almas no inferno influenciaram a fé

\footnotetext{
${ }^{246}$ Cf. Ibid., p. 235-236.

${ }^{247}$ Cf. Ibid., p. 231-233.

${ }^{248}$ Ibid., p. 233-234.

${ }^{249}$ A compreensão de Küng diante da influência do mal sobre a humanidade. Mesmo que se possa considerar uma influência má que transcenda o ser humano, a personificação do mal, de satã e demônios, se deve a influência da religião persa sobre o povo de Israel, durante o período de permanência na Babilônia, continuando na tradição judeu-cristã. O Antigo Testamento sobre a crença nos demônios é bastante reticente. Jesus não polemiza e nem tematiza o assunto, da forma que hoje vemos, mas antes, se interessa em pregar o reino de Deus e a sua bondade, buscando livrar o homem dos males do seu tempo. A cura e expulsão de demônios por Jesus é um sinal de que o reino de Deus está próximo e que o poder do diabo chegou ao fim (Cf. Ibid., p. 224-226).
} 
popular no Ocidente. Apesar disso, a questão do inferno não está resolvida, no âmbito católico. O Concílio Vaticano II não tratou diretamente a questão. Então o que vale agora? A questão não deve ser silenciada, afirma Küng. ${ }^{250}$

Küng afirma que teólogos notáveis, como Orígenes, Gregório de Nissa e Jerônimo ensinaram que as punições do inferno impostas aos maus são temporárias. ${ }^{251}$ E para Ambrósio, assim como para os três últimos, o fogo do inferno foi interpretado no sentido metafórico. Küng reconhece que Jesus também falou do inferno, usando representações do seu tempo. Representações conforme também usada pela apocalíptica, e poderia também ter compartilhado destas ideias. Porém, Jesus não era um pregador do inferno. Em nenhuma parte revela verdades especiais a respeito do além. Não descreve minúcias, torturas e condenações como é feito posteriormente, a partir do século II. Diversos temas do Novo Testamento foram muitas vezes abordados com concepções diferentes, por que deveria justamente neste caso, a força da imagem do "fogo eterno", ser compreendida ao pé da letra, literalmente? ${ }^{252}$

Para Küng as referências do Novo Testamento ao "fogo do inferno" poderiam ser apenas metáforas para indicar a possibilidade do ser humano abortar inteiramente o significado da vida. Diante desta advertência a vida seria orientada para uma significação positiva. Küng descreve o que acredita com relação ao fogo eterno:

O "fogo" é a imagem da ira de Deus, e "eterno" no uso do hebraico, grego e até mesmo moderno, nem sempre se toma em sentido estrito ("isto é, eterna", "dura uma eternidade", que não tem fim, indefinidamente longo). Ao falar de "pena eterna" de Julgamento, que coloca a ênfase sobre que o castigo é definitivo, decisivo para toda a eternidade, mas não que o castigo durará para sempre.... Mas seja qual for a interpretação dos textos da Escritura, em particular: em nenhum caso cabe afirmar a "eternidade" do castigo do inferno. Mais é subordinado a Deus, sua vontade e sua graça. ${ }^{253}$

Em outra obra, Küng, mantém a sua compreensão relacionada a duração do tormento eterno, e dispara:

\footnotetext{
${ }^{250}$ Cf. Ibid., p. 216-219.

${ }^{251}$ Cf. KÜNG, Hans. Credo: The Apostles' Creed Explainede for Today, New York, Doubleday, 1993, citado em: LA DUE, Willian J. O guia trinitário para escatologia. São Paulo: Loyola, 2007, p. 114-115.

${ }^{252}$ Cf. KÜNG, Hans ;Vida Eterna?, op. cit., p. 222-223; 236-237.

${ }^{253}$ Ibid., p. 237.
} 
Na punição eterna (Mt 25,46) do Juízo Final, a ênfase recai no fato de que essa punição é definitiva, final, decisiva para sempre, não em que o tormento deve durar eternamente.[...] É uma contradição aceitar o amor e a misericórdia de Deus e, ao mesmo tempo, a existência de um lugar de tormento eterno. Não, a punição do inferno, como tudo o mais, contínua subordinada a Deus, à sua vontade e à graça. ${ }^{254}$

As advertências são relacionadas àqueles (as) que não levam com seriedade o sentido último da vida, e vivem em oposição a esta realidade. As imagens do Inferno, no Novo Testamento, como um lugar de seu possível destino (a danação), não devem ser tomadas literalmente, mas como uma advertência, como a possibilidade de ser excluído da comunhão eterna com Deus. Por isso as imagens de desespero no Novo Testamento. ${ }^{255} \mathrm{O}$ sentido último da vida seria consumado no encontro com a realidade de Deus.

Sobre o julgamento de Deus para com os seres humanos, Küng afirma: “isso compete exclusivamente a Deus que julga benevolentemente: o último e incompreensivo ato da graça de Deus." 256

Com relação a ideia de restauração universal (apokatástasis), proposta desde Orígenes, Küng entende que ela não corresponde à seriedade da vida e o sentido da responsabilidade humana:

Universalismo frente, para o qual todos os homens são previamente salvos, não corresponderiam (como veremos mais adiante) com a seriedade da vida, nem satisfaria a importância de decisões éticas e a gravidade da responsabilidade individual. Seja ou não a punição eterna do inferno, o homem é plenamente responsável, não apenas à sua consciência, que é a voz da razão prática, mas antes a última instância, que também é responsável por sua própria razão. E, obviamente, seria temerário, por outro lado, que o homem destinado a antecipar o julgamento sobre a sua a vida, reservado como último recurso. Nem de uma nem de outra maneira podemos amarrar as mãos de Deus.... Aqui não há nada que saber, só esperar. $^{257}$

\subsection{4}

\section{A ressurreição do corpo e a ascensão de Cristo}

Após discorrer sobre os textos que narram a ressurreição de Jesus, Küng responde com toda precisão: a ressurreição de Cristo não é um acontecimento histórico, mas sim um acontecimento real.

\footnotetext{
${ }^{254}$ KÜNG, Hans. Credo, citado em: Id., ; Vida Eterna?, op. cit. p. 114-115.

${ }^{255}$ Cf. Ibid., p. 239.

${ }^{256}$ Ibid., p. 230.

${ }^{257}$ Ibid., p. 238.
} 
O que isso significa? A afirmação "ressuscitado ao terceiro dia" não é um dado histórico e sim teológico. Pois o número três é simbólico. A ressurreição de Jesus se relaciona com a vida eterna, está para além das categorias de espaço e tempo verificáveis, e não pode ser penetrada pelo historiador e verificada por métodos a nossa disposição. Só a morte de Jesus e em seguida a fé e a mensagem da Páscoa dos discípulos são historicamente verificáveis. A ciência histórica, a química, a biologia, a psicologia, a sociologia e a teologia não captam mais que um dos múltiplos aspectos da realidade. Como a questão da ressurreição, a criação e a consumação final não podem ser respondidas por estas ciências, agora entra em jogo a única resposta: a realidade de Deus. Porque o que entra em jogo na reanimação (ressurreição) é a ação de Deus, evento real no sentido mais profundo da palavra. Não fictício ou imaginário, para aquele que não quiser ficar neutro diante dos acontecimentos, mas como crente se abandona a fé. Ultrapassa os limites da história. Transcende a dimensão da morte humana para dimensão abarcadora de Deus. Um modo de existir absolutamente novo na dimensão do eterno. $\mathrm{O}$ sentido da linguagem deve ser interpretado como figurada. $\mathrm{O}$ verdadeiro milagre da ressurreição consiste que Deus tem a palavra final, onde do ponto de vista humano tudo se havia acabado. ${ }^{258}$ Sendo este o milagre da nova criação da vida a partir da morte. Um apelo e uma oferta de fé, a única que pode ter acesso à realidade do Ressuscitado. Küng descreve o que está em jogo:

O que está em jogo aqui é bem mais que a pessoa de Jesus, portanto, sua causa. Não se pode prescindir da pessoa do Ressuscitado. É Deus mesmo que pela ressurreição de Jesus decide sobre sua causa, que seus discípulos haviam dado por perdida. Assim a causa de Jesus segue adiante e tem sentido, porque Jesus mesmo não foi fracassado, na morte, mas completamente legitimado por Deus, vive! Portanto, não há novas revelações de Deus, mas o próprio Jesus é manifestado como o verdadeiro revelador de Deus. Durante sua vida, e contrariamente ao que a compreensão literal das Escrituras-conservadora dos líderes do templo, Jesus tinha apelado ao Deus de vida e advogado pela a ressurreição dos mortos. Agora, os discípulos de Jesus se referem ao mesmo Deus da vida, pregando a ressurreição de Jesus crucificado. ${ }^{259}$

\footnotetext{
${ }^{258}$ Cf. Ibid., p. 177-179. Com a relação à narrativa sobre a descida de Jesus ao inferno e a sua atuação neste e a sua ascensão (Cf. 1Pedro 3,18-20). Hans Küng, após discorrer (Cf.Ibid., p. 208222) sobre a historicidade dos textos, a interpretação dada a eles no decorrer da Tradição cristã, a problemática de sua fundamentação nas Escrituras, e o fato destas narrativas estarem muito mais condicionadas, que outras, pelas antigas imagens do mundo, e o entre outras avaliações, Küng observa que estas narrativas não devem ser entendidas literalmente (Cf.Ibid., p. 222).

${ }^{259}$ Ibid., p. 179-180.
} 


\title{
E continua:
}

Fé na ressurreição, uma atitude de confiança e esperança de um conjunto razoável de recursos para a realidade e a eficácia do Deus que em Jesus tem superado a morte. (...). Assim, a ressurreição é indiscutivelmente um acontecimento de fé (...). O pressuposto desta nova vida é a prioridade - não temporal, mas objetiva, real- da ação divina. Só assim se é possível, suscitar essa fé em que o mesmo Vivente aparece vivo. A mensagem da ressurreição, em suma, é testemunho de fé, mas não produto de fé (...). O Crucificado vive para sempre junto a Deus - como compromisso e esperança conosco. ${ }^{260}$

A confiança é que Cristo morreu e ressuscitou, e que todos que o seguem também ressuscitarão. Nova vida, vida eterna. Essa fé chama todos a viverem e morrerem com ele. É uma mensagem verdadeiramente subversiva e revolucionária, e fácil de recusar. Esta é a realidade para Küng:

O cristianismo enquanto confissão de Jesus de Nazaré como o Cristo vivo e poderoso, começa com a Páscoa (...). Sem Páscoa o Cristianismo não é a fé em Cristo, ou o anúncio Cristo, nem Igreja, nem o culto divino, nem missão! ${ }^{261}$

Os cristãos afirmam que haverá uma ressurreição geral dos mortos. Porque Cristo ressuscitou há esperança para esta ressurreição, não podendo dissociar-se a ressurreição de Cristo com uma ressurreição geral ${ }^{262}$. Os que confiaram em Jesus Cristo, e viveram a vida conforme suas orientações participarão da vitória de Deus sobre a morte. Jesus é a primícias e o primogênito ${ }^{263}$ de todos os mortos.

O que significa, mais precisamente, a ressurreição ${ }^{264}$ do corpo para Küng? Essa ressuscitação do corpo é concebível? Como se deve imaginar uma ressuscitação? Resposta de Küng: de maneira nenhuma. Ressuscitação e

\author{
${ }^{260}$ Ibid., p. 180. \\ ${ }^{261}$ Ibid., p. 182. \\ ${ }^{262}$ Cf. 1Coríntios 15. \\ ${ }^{263}$ Cf. 1Coríntios 2, 9; 15, 20; 19; Colossenses 1, 8; Apocalipse 1, 5.
}

${ }^{264}$ A pedido da IHU On-Line, Hans Küng enviou um artigo sobre a ressurreição onde diz: "Afinal a ressurreição está ligada a quê? Não ao substrato constantemente a mudar ou aos elementos deste corpo particular, mas sim à identidade dessa pessoa inconfundível. O caráter físico da ressurreição não exige - nem outrora nem hoje - que o corpo morto seja reanimado. Pois, Deus ressuscita o Homem numa nova forma, inimaginável, como consta do paradoxo de Paulo: como "soma pneumatikón", de "caráter físico-espiritual". Com estas palavras, de fato, paradoxais, Paulo pretendia transmitir-nos simultaneamente as seguintes duas mensagens: continuidade - porque o "caráter físico" representa a identidade da pessoa até ao momento, que se desfaz, como se a história vivida e sofrida até ao momento se tivesse tornado irrelevante - e, simultaneamente, descontinuidade - porque o "caráter espiritual" não representa simplesmente a continuação ou a reanimação do antigo corpo, mas sim a nova dimensão, a dimensão do infinito, que depois da morte de tudo o que é finito se transforma, tem seu efeito." Disponível em: http://www.ihuonline.unisinos.br/index.php?option=com_content\&view=article\&id=2458\&secao $=288$. Acesso em: 28 de abr. 2012. 
ressurreição são termos metafóricos. Seria uma radical transformação, um estado completamente novo, distinto: a vida eterna. E não há nada para imaginar, representar e objetivar. A nova vida é para nós suscetível de esperança, mas inteiramente inacessível à intuição e a representação. ${ }^{265}$

Para Küng, quando o Novo Testamento fala de ressurreição se refere à nova criação, a transformação do ser humano inteiro por obra do Espírito vivificante de Deus. Não que o ser seja resgatado de sua corporeidade, mas que é resgatado com sua corporeidade, agora glorificada e espiritualizada. A Páscoa é a festa não da imortalidade, mas a festa do Crucificado glorificado. A ressurreição não se trata do restabelecimento da corporeidade. Trata-se da identidade da pessoa. A questão é da significação de toda minha vida e todo meu destino. Toda história individual reencontrada em Deus, pode-se entender como história consumada. ${ }^{266}$ Küng cita Wilhelm Breuning: "a ressurreição do corpo significa que o homem reencontra em Deus toda sua história" ${ }^{267}$. E continua:

Se a realidade última não é o nada, mas esse todo que chamamos de Deus, a morte não é uma destruição, mas uma metamorfose: "vita matutus, non tollitur" (a vida não termina, se transforma), a afirma o prefácio a missa de defuntos. Assim, pois não é terminar (Enden), nem sucumbir (Vereden), mas um perfeito ou consumado (Volleden); não uma diminuição, mas uma consumação, a infinita consumação. ${ }^{268}$

$\mathrm{Na}$ abordagem de Küng, a ressurreição literal pode ser confundida com a ressurreição da pessoa pela ação do Espírito de Deus. Portanto a ascensão de Cristo pode ser descrita como a assimilação de Jesus na vida de Deus. ${ }^{269}$ Categoricamente Küng afirma: “a ressurreição para vida (...) nunca deixará de ser uma esperança vã, ilusória, enquanto não está baseada e sustentada em uma ressuscitação para vida, mas além da morte.",270

\footnotetext{
${ }^{265}$ Cf. KÜNG, Hans ¿Vida Eterna?, op. cit., p. 185; 189.

${ }^{266}$ Ibid., p. 189.

${ }^{267}$ BREUNING, Breuning. Gericht und Auferweckung von den Toten ais Kennzeichen des Vollendungshandeln Gottes durch Jesús Christus. en J. Feinery M. Lóhrer (edit.). Zurich: Mysterium Salutis, 1976, V, 882, citado em: KÜNG, Hans $\underset{6}{ }$ Vida Eterna?, op. cit., 2007, p. 190.

${ }^{268}$ KÜNG, Hans ¿Vida Eterna?, op. cit., p. 190.

${ }^{269}$ Cf. Ibid., p. 192.

${ }^{270}$ Ibid., p. 201.
} 


\section{7 Críticas e defesas a Hans Küng}

É fácil perceber que o nome Hans Küng não é bem vindo em muitos lugares. Basta observar alguns aspectos de sua teologia onde contesta e confronta algumas concepções tradicionais da Igreja Católica Romana, não escapando também a oposição à diversas concepções da teologia protestante. A compreensão tradicional da teologia ocidental como a Deidade de Jesus, Nascimento Virginal, Imaculada Conceição, Pecado Original, Purgatório, Inferno, Inerrância Bíblica, o conceito Tradicional de Deus e os Milagres encontram em Hans Küng uma confrontação. Normalmente Küng é criticado como quem se ancora demasiadamente no método histórico-crítico, sendo um teólogo contestador e um modernista radical. ${ }^{271}$

Outra crítica que pode se desferida contra o teólogo, é sobre sua postura a favor da eutanásia, em determinadas situações, e do aborto, nos períodos iniciais da fecundação. Poderia ser criticado, se não seria contraditório ser a favor do aborto, enquanto se é contrário à manipulação genética para se criar um ser humano melhor, isto é, um ser superior aos atuais seres humanos, e ao mesmo

\footnotetext{
${ }^{271}$ Por não se tratar de uma pesquisa de cunho dogmático estas questões cruciais são apenas sinalizadas, sem a pretensão de confrontá-las. No entanto, estas respostas são facilmente encontradas nos tratados de dogmática, católicos ou protestantes. Apenas sinalizamos que a postura de Küng em relação à Deidade de Jesus e a Trindade rompem com concepções cruciais do Símbolo Apostólico: a) a natureza divina relacional de Deus, se constituindo amor em si mesmo: pensar em Deus como Trindade é afirmar uma sociedade ou relacionamentos dentro de Deus. Os seres humanos criados à sua imagem são chamados a compartilhar esta, compartilhando este amor com próximo, fracassando quaisquer comportamentos e ideologias individualistas a partir do Deus-em-Trindade. A Trindade é vital para a espiritualidade cristã. Toda espiritualidade autêntica é trinitária. Pelo alcance das implicações práticas, a Trindade constitui o coração e alma da espiritualidade cristã, sendo a pedra fundamental por sintetizar toda a "economia" do relacionamento de Deus com a criação e a humanidade. Relacionando-se com a abertura da humanidade à transcendência. É paradigma para a unidade de toda realidade. Como vocação da humanidade é sermos deificados, tornados como Deus, somos arrastados para dentro da própria comunidade de Pai, Filho e Espírito (Cf. SHELDRAKE, Philip. Espiritualidade e teologia: vida cristã e fé trinitária. São Paulo: Paulinas, 2005, p. 30-31; Cf. RATZINGER, Joseph. Introdução ao cristianismo: preleções sobre o Símbolo Apostólico. São Paulo: Herder, 1970, p. 141); b) A doutrina cristã de Deus compreende nesta relação o equilíbrio entre transcendência e imanência: "crença na encarnação também convida as pessoas a adotar uma abordagem equilibrada com a natureza humana e especialmente com sua dimensão material, o corpo. Isso não deve ser nem radicalmente pessimista nem otimista. A encarnação é mais que uma defesa da realidade e importância da natureza humana de Jesus Cristo. Ela é um princípio regulador da vida cristã; do modo como Deus se relaciona com o mundo e o modo como reagimos. O que significa que a visão cristã de Deus, e a auto-revelação de Deus, força a espiritualidade a atribuir uma importância fundamental à história humana e à existência material” (Ibid., p. 31).
} 
tempo afirmar que a utilização da vida humana fecundada, para criação de órgãos, deve caber aos especialistas da área da biologia, medicina, direito e da ética. ${ }^{272}$

Küng considera que o aborto, nos período iniciais da gestação, se refere a eliminação de uma vida, mas não de uma pessoa, pelo fato das características peculiares que constituem uma pessoa apenas se formar nos períodos mais avançados da gestação. No entanto, se a proposta de um ethos mundial, tem como fundamento o respeito à vida e a dignidade humana, não seria conflitante, esta eliminação da vida, sabendo que esta fase é necessária para que todos se tonem pessoa?

No entanto, atualmente, as censuras de maior peso a Küng versam sobre sua postura crítica em relação à Instituição Católica Romana e ao papa, hoje, Joseph Ratzinger, o Bento XVI. Sobre a crítica de Küng à decisão do papa de acolher os tradicionalistas anglicanos (incluindo bispos, pastores e seminaristas) o jornal da Santa Sé, o L'Osservatore Romano, se arremeteu com grande contundência sobre o crítico do Pontífice. O editorial assinado pelo diretor do jornal do Vaticano, o historiador Giovanni Maria Vian, intitulado Distante da Realidade, aponta as críticas de Küng como injustas, duras, sem fundamento e principalmente, falsas e inexatas. $\mathrm{O}$ artigo, desde a primeira linha, lamenta que mais uma decisão de Bento XVI é vista de forma preconceituosa e distante da realidade pelo teólogo suíçoalemão. Este editorial, em certo sentido, contra-ataca outro texto de Hans Küng, $O$ Papa que pesca nas águas da direita, no qual Ratzinger, dentre outras coisas, é acusado de "engordar" as fileiras da Igreja abrindo as portas para o ingresso de grupos mais reacionários e conservadores, e o sim aos anglicanos tradicionalistas é vista como uma tragédia ecumênica. Para o jornal da Santa Sé, as declarações de Küng nestes dois artigos apresentam uma representação fosca e infundada da Igreja Católica e de Bento XVI, que para tal propósito, Küng, utiliza-se da mídia influente, atacando a Igreja de Roma com falsidades e inexatidões. ${ }^{273}$

No entanto, Küng reconhece que teve êxito em seus escritos, produzindo uma literatura que torna o cristianismo, a religião e a ética novamente

\footnotetext{
${ }^{272}$ A postura encontrada em: KÜNG, Hans. Para que um ethos mundial?, op. cit., p. 108-109.

${ }^{273}$ A reportagem é do jornal italiano La Repubblica, 29 de out. 2009. A tradução é de Moisés Sbardelotto. Disponível em: a igreja se insurge contra o teólogo Hans Küng.
} 
compressiva na contemporaneidade. Alegando que sua profissão não é ser crítico do papa, nem que seja um subversivo da Igreja, mas sim um reformador. ${ }^{274}$

Sobre o Projeto de ética mundial, uma crítica surge do professor de filosofia Manfredo Araújo de Oliveira ${ }^{275}$. Ele alega que a intuição de Küng para solucionar os grandes problemas da humanidade implica no estabelecimento de um consenso ético mínimo. Isto está correto, porém, o problema se encontra no fato de fundamentar a sua proposta ética na religião, deixando em penumbra o aspecto político. Mesmo que do ponto de vista motivacional a referência as religiões seja importante, para a realização de um estilo de vida nas comunidades religiosas, não adianta tal estilo se a questão é estritamente política. Manfredo de Oliveira diz que o teólogo em questão afirma: a) só a religião é capaz de fundamentar o caráter incondicional das normas éticas; b) fora da religião não há possibilidade de fundamen vtação do caráter incondicional dos princípios normativos. Logo, afirma o professor de filosofia, como Deus não é demonstrável racionalmente, mas fruto de crenças, e se estas crenças fundamentam o caráter incondicional da ética, todas as éticas são, no fundo, crenças, sendo assim, jamais poderão dizer algo a respeito a todos os seres humanos. Questiona como fundamentar na base de pura crença a solução para os grandes desafios do mundo contemporâneo. Tanto é assim, alega o professor, que no Brasil quando as questões éticas fundamentais estão em jogo, não se permite a participação das religiões, pois o estado é laico, desta forma não se permite que um grupo religioso imponha suas convicções sobre os demais. Competindo a razão e não a religião o que é comum nas culturas da humanidade. No entanto, concorda com Küng sobre a necessidade de diálogo para solucionar as diferentes perspectivas dos problemas universais, pois estes se referem a todos os povos. Para Manfredo de Oliveira, não será possível enfrentar as questões concretas da realidade sem enfrentar uma teoria do mundo, o mundo concreto humano e natural, sem saber o que é o mundo. Para construção desta teoria, será necessário superar a dicotomia deixada pela Modernidade que separa o

\footnotetext{
${ }^{274}$ Cf. A reportagem é de Arno Luik, publicada na revista alemã Stern, 15 de out. 2009 (Cf. nota 183 da página 74 , desta dissertação).

${ }^{275}$ Entrevista concedida à IHU On-Line, pessoalmente, durante o Congresso da Sociedade Brasileira de Teologia e Ciencias da Religião - SOTER, realizado na cidade de Belo Horizonte. Disponível em:http://www.ihu.unisinos.br/entrevistas/9010-o-projeto-de-etica-mundial-de-hansk\%C3\%BCng-entrevista-especial-com-manfredo-araujo-de-oliveira. Acesso em: 28 de abr. 2012.
} 
ser humano e mundo, sujeito e objeto e teoria e realidade. A partir daí, pode-se buscar soluções concretas e racionais e não abstratas.

Poderíamos perguntar como poderia ser uma teoria de mundo sem levar em consideração a concretude das ações religiosas na humanidade? $\mathrm{O}$ veto dado à contribuição das religiões na busca da solução dos grandes desafios da contemporaneidade não seria uma herança da Modernidade?

Olhando para os escritos de Küng, tem-se a impressão que o mesmo reconhece a autonomia política na construção dos valores éticos da humanidade, ao mesmo tempo, que reconhece a limitação da mesma para tal construção efetiva, observando o panorama histórico mundial. A postura de Küng aponta para sua máxima: não é possível paz entre as nações sem paz entre as religiões. Logo, entende que é necessário também um consenso ético entre as mesmas, e sobre esta questão a história parecer atestar. É possível perceber neste teólogo que a política, que se encontra limitada em estabelecer padrões éticos dentro dos seus próprios e restritos arraiais, deveria contar com a possibilidade de um consenso ético mínimo estabelecido entre as religiões, o que seria um grande passo para a paz e o entendimento da humanidade. O que está em jogo não é a prioridade, seja da política ou da religião, mas a capacidade de cumprir o propósito de um consenso ético mínimo que atinja positivamente os seres humanos, proporcionando a dignidade da vida. E sobre este mínimo consenso, Küng alega encontrá-los em todas as grandes religiões. Pelo diálogo Küng busca, dentre outras coisas, o respeito a não imposição da própria crença ao outro. O teólogo observa:

Cada uma das religiões possui a sua própria verdade original, que nunca é apenas uma verdade teórica, mas sim uma verdade prática. Trata-se não só apenas de conhecimento verdadeiro, mas também de um agir correto. Não estamos falando só de doutrinas, mas também de um ethos. ${ }^{276}$

Küng prefere falar em "regras elementares", ou um "sistema de coordenadas", e não em "um consenso mínimo". Sendo a proposta de seu ethos baseada nestas regras, presente nas grandes religiões e em vários segmentos da sociedade. Acredita que, se fosse aceito, muitos conflitos religiosos teriam sido evitados. Não busca substituir as diretrizes básicas das religiões e nem criar uma nova religião, mas apenas expressar o que já está implícito nelas e nos grandes

${ }^{276}$ Cf. Para que um ethos mundial?, op. cit., p. 23. 
textos da humanidade que podem ser aplicadas a todos, incluindo os não-crentes. Constituindo uma moral básica comum, uma vez que a humanidade se pôs a caminho da globalização, será necessário um código de ética comum a todos. ${ }^{277}$

Para Küng o fanatismo religioso é um risco para a paz mundial, fato que aumenta o interesse pelo diálogo inter-religioso e pelo ethos mundial em círculos que antes haviam se mostrado avessos a estas propostas, incluindo os políticos. ${ }^{278}$

Alega que a dimensão mais profunda do ser humano pode ser tocada pela religião de uma maneira eficaz. Neste contexto, pode ser mais profunda do que a filosofia ou política. A força que a filosofia não conhece na mesma proporção, consiste no fato da religião não transmitir apenas ideias, mas um modelo de vida e de morte, uma verdadeira opção de vida, que vale a pena comprometer-se com ela. Com todo respeito e amor à filosofia, Küng alega que Sócrates não pode ser comparado a Moisés, como Aristóteles não chega a ser nenhum Cristo. A obediência absoluta à realidade última, mas não a qualquer autoridade secular ou religiosa, é um reforço para o ethos, que não é simplesmente um projeto religioso, mas leva a sério todas as religiões. Afirma ser ilusão pensar, fazer política sem levar a sério a religião, quer queira quer não, ela faz parte da estrutura básica da sociedade como a música, a arte e o direito, no entanto, cuidando que não haja absolutismo de nenhuma destas áreas para que o ser humano não seja menosprezado. $^{279}$

Küng não hesita, alega que para haver paz no Oriente Médio será necessário levar a sério a dimensão religiosa do conflito. As questões desta região não devem ser abordadas apenas pela dimensão política ou religiosa, mas considerando estas duas realidades. ${ }^{280}$

Ainda que exista, ou se exija a possibilidade de discussão e aprofundamento sobre a questão da religião, poder fundamentar o caráter incondicional das normas éticas, este questionamento, no entanto, não pode ser realizado em relação da necessidade absoluta e urgente da religião ser considerada com seriedade nas

\footnotetext{
${ }^{277}$ Cf. Ibid., p. 25-26; 29-32; 40; 73

${ }^{278}$ Cf. Ibid., p. 74; 77-78.

${ }^{279}$ Cf. Ibid., p. 78; 82; 84-86.

${ }^{280}$ Cf. Ibid., p. 91. Corroborando com a postura de Küng, vale observar Hevier-Leger. A autora advoga uma laicidade mediadora para solucionar os conflitos político-religiosos que acomete a França, na atualidade. A proposta baseia-se em: a) numa "virada cooperativa" nas relações entre as famílias espirituais e o Estado; b) na dinâmica das relações inter-religiosas e a recomposição da laicidade (Cf. HERVIEU-LÉGER, Danièle, op. cit., p. 221-230).
} 
discussões e planejamentos dos projetos político. Esta necessidade se constitui como imperativa. Afinal, quais são os valores que devem ser assegurados e sustentados pelas ordens políticas? Deveria a religião e as expressões religiosas serem excluídas, tendo em vista o conflituoso cenário mundial?

Deve-se lembrar que o Estado é laico, mas não ateu. E o mesmo está a serviço da nação, devendo proporcionar, permitir e reconhecer todas as expressões que possam colaborar com a formação integral e que ofereçam fonte de sentido aos seus integrantes.

Manuel Fraijó declara que vislumbrou desde a sua tese de doutorado, que seria um homem ecumênico, que advogaria pelo respeito, pela tolerância e diálogo e que se deixaria guiar pelo Espírito sendo pioneiro e valente. A Igreja não seria a mesma sem pessoas como Hans Küng. ${ }^{281}$

Sobre Küng, continua Fraijó: o seu serviço é crítico, vigilante, incômodo e arriscado, mas necessário. Com sua teologia enraizada numa rigorosa e exigente reflexão filosófica, iniciada com sua tese de doutoramento, onde com coragem e juventude, estendeu pontes de diálogo e compreensão para uma temática que havia dividido católicos e protestantes desde os inícios da Reforma. Mesmo nos momentos de intenso conflito, não deixou a Igreja mátria. Fraijó acredita que devemos muito à seu espírito visionário,utopias e suas esperanças de dias melhores para o futuro de todos os seres humanos. ${ }^{282}$

As reflexões e teologia de Hasn Küng constituem uma enorme colaboração para teologia e para o cristianismo. Lançando luz sobre temas delicados referentes ao ser humano, a religião e a ética na atualidade de secularização e globalização. Utilizando-se de suas próprias experiências de esperanças e desventuras, da peculiaridade de sua teologia, para possibilitar que os seres humanos, no mundo secularizado, possam compreender o sentido último da existência e sua responsabilidade perante a realidade. Mesmo diante de uma avalanche de críticas, continua empreendendo empenho e esforço na sua causa em prol da mensagem cristã.

\footnotetext{
${ }^{281}$ Conforme reportagem publicada no sítio Religión Digital, 24 de jan. 2011. A tradução é de Anne Ledur. Disponível em: http://www.ihu.unisinos.br/noticias/40194-a-igreja-precisa-depessoas-como-hans-kueng-e-bento-xvi. Acesso em 28 de abr. 2012.

${ }^{282}$ Conforme artigo publicado no jornal espanhol El País, 25 jan.1011. A tradução é do Cepat. Disponível em: http://www.ihu.unisinos.br/noticias/40253-o-olhar-critico-e-necessario-de-hanskueng. Acesso em 28de abr. 2012.
} 


\section{4 \\ Hans Küng: contribuições para a vivência cristã no mundo de secularização}

Neste capítulo serão apresentados alguns aspectos relevantes das reflexões do teólogo suíço Hans Küng, como possibilidade de superação das implicações teológico-pastorais, descritas no capítulo primeiro dessa pesquisa, tendo como objetivo proporcionar uma instrumentalização e contextualização para que o cristianismo seja anunciado e vivido com equilíbrio, coerência e maturidade, apresentando-se como relevante em sua missão na sociedade secularizada.

\section{1}

\section{A legitimação do cristianismo no mundo secular}

Diante do fato das grandes religiões se encontrarem cada vez mais próximas das sociedades contemporâneas - pelo processo de globalização - e diante da multiplicidade de experiências religiosas e diversas espiritualidades que alegam genuinidade, autenticidade e reconhecimento de suas expressões, surge uma pergunta: como legitimar de forma adequada a missão evangelizadora cristã? Não seria essa inspiração uma tentativa de imposição sobre demais expressões religiosas? Não seria uma postura que desconhece ou não leva em consideração a capacidade salvífica das demais formas religiosas e espiritualidades? Como legitimar a ação do cristianismo no Ocidente secularizado? Esses questionamentos tornam a postura cristã em sua missão e pastoral mais complexa e desafiadora na cultura plurirreligiosa hodierna.

O ponto de equilíbrio deveria levar em consideração que a esfera secular e a esfera religiosa não podem ser consideradas como porta voz exclusivas da sociedade, uma excluindo a outra. Tais esferas são legítimas na história da civilização ocidental, devendo legitimar-se por si mesmas, o mesmo podendo se dizer das demais religiões que se apresentem como propostas de orientação. Essa legitimação não deve ser de exclusão, nem de supremacia, mas de integração, onde cada uma dessas esferas utilizará de seus meios para promoção do bem, da verdade, da justiça e da paz, promovendo e preservando os direitos e deveres para 
o desenvolvimento da dignidade humana, da sua humanização radical e do entendimento na busca da construção de um ethos para a paz mundial.

A legitimação deve ser direcionada ao que é propriamente mais adequado para o ser humano se tornar mais humano, e para perpetuação do mesmo, sendo atestado historicamente como justo e verdadeiro para este propósito, seja fruto do braço religioso ou do braço secular. ${ }^{283}$

Dessa forma, tanto os proponentes da secularidade radical, quanto os proponentes do cristianismo, pelo menos hoje - já que no passado a ferida em consequência dos traumas da ruptura entre essas esferas não permitiria uma reflexão adequada por ambos os lados - deveriam levar em consideração que são apenas um dos traços físionômicos da sociedade, e não propriamente sua fundamentação última e inexorável raiz primordial, independentemente da proeminência de uma dessas esferas em determinados períodos da história. ${ }^{284}$

O Estado Democrático, que se constituiu secularizando-se com o processo de racionalização, instrumentalização e da burocratização jurídico-política, afastando-se das amarras da concepção da esfera religiosa, deve compreender a contribuição do cristianismo, não só no passado, mas ainda hoje, como realidade que pode, de maneira eficaz, colaborar para ação do Estado, como também para o desenvolvimento positivo da sociedade. O cristianismo dever possuir a mesma postura para compreender a colaboração da esfera secular, visando o mesmo propósito para o bem dos seres humanos. Assim, deve estabelecer-se o diálogo

\footnotetext{
${ }^{283}$ Cabe, aqui, o excelente artigo do Papa Bento XVI, enquanto cardeal, Joseph Ratzinger: RATZINGER, Joseph. Fé, verdade e cultura: reflexões a propósito da encíclica Fides et Ratio I. In: COMMUNIO. Revista Internacional Católica. Ano XVI, n ${ }^{\circ}$, outubro de 1999, p. 464-472. Sendo a parte II do mesmo artigo publicado na edição seguinte da mesma revista, p. 557-568. Neste artigo é demostrado que a integração entre a esfera secular e a religiosa deve interagir para promoção da verdade.

${ }^{284}$ Paul Veyne discorda que a Europa possua o cristianismo como raiz principal da mesma, sendo o cristianismo apenas um dos traços desta sociedade: VEYNE, Paul. Quando nosso mundo se tornou cristão: 312-394. Rio de Janeiro: Civilização Brasileira, 2010. p. 199-240. Ainda que os argumentos de Veyne sejam válidos, não se pode perder de vista o que diz Küng: "mas só os ignorantes ou os mal-intencionados poderiam afirmar que o cristianismo não havia mudado o mundo para melhor" (KÜNG, Hans. A Igreja Católica. op. cit., p. 57); e Troeltsch: "Os seguidores do cristianismo devem aprender a considerar [o mundo moderno] como proveniente do cristianismo e alimentado por ele; e seus inimigos devem tomar consciência de que, se é possível desvincular o cristianismo de momentos isolados, jamais será possível desvinculá-lo de uma inexistente totalidade do mundo moderno" (citado por: ROSINO, Gibellini. op. cit., p. 123-124). O Ocidente, ainda que tenha conhecido a Inquisição, as Cruzadas, a caça as bruxas e aos hereges se livrou de atentados diretos a dignidade humana cometida em outras religiões, realizada não apenas no passado, mas ainda hoje. Aborda as mudanças cruciais realizadas pelo cristianismo: KENNEDY, D. James; NEWCOMBE, Jerry. E se Jesus não tivesse nascido? São Paulo: Editora Vida, 2003.
} 
para atingir o objetivo comum, para o bem da própria civilização sob a influência concomitante dessas esferas. Ambas, buscando dentro de suas forças e capacidades o que é melhor para vida humana, devem clarificar mutuamente suas próprias e respectivas missões, ${ }^{285}$ e legitimando-se não pela força, coação, medo, ou qualquer outra forma opressora, violenta ou por argumentos sofismático sendo essa condição a pedra angular para sua legitimação ou descrédito, para desvendar a falsidade ou veracidade da sua própria constituição salvífica intrínseca.

No entanto, essa legitimação fica obstruída ou comprometida quando o interesse político, religioso e dos mais diversos setores da sociedade civil entram em jogo com interesses excusos, trivializado, desvirtuando ou desconsiderando a ética, a moral, a verdadeira religiosidade, a religião.

A religião, em nosso caso o cristianismo - apesar de decrescer sua evidência na consciência e na cultura da sociedade ocidental - conseguindo apresentar sua essência à atual sociedade, poderá esclarecer o seu direito, o seu sentido e sua realidade como integrante fundamental da vida humana, ${ }^{286}$ Legitimando-se enquanto fundamentada na transcendência e não como fenômeno utilitarista de caráter mágico-religioso, ou enquanto identificada como expressão política, ideológica ou socioeconômica.

\section{2 \\ Considerações pastorais}

Enquanto, percebemos que a secularização não deveria implicar em descristianzação, anticlericalismo, laicismo ou ateísmo poderíamos nos perguntar por outro lado, como perpetuar uma instituição cristã - pricipalmente em relação à Igreja Católica - cujo muito de seus pressupostos não são mais socialmente aceitos? Para Grumelli, a resposta à secularização deverá ser respondida no campo da teologia com equilíbrio em duas posturas fundamentais, isto é, uma de defesa e outra de acomodaçao, com variações em seu interior. No entanto, ambas

\footnotetext{
${ }^{285}$ Para aprofundar as discussões do debate político-religioso: HABERMAS, Jürgen; RATZINGER, Joseph. Dialética da Secularização: sobre razão e religião. Aparecida: ideia e Letras, 2007; FERRY, Luc; GAUCHET, Marcel. Depois da Religião: o que será do homem depois que a religião deixar de ditar a lei? Rio de Janeiro: DIFEL, 2008; HUNTINGTON. Samuel. O Choque de Civilizações: e a recomposição da Ordem Mundial. Rio de Janeiro: Objetiva, 1997.

${ }^{286}$ Cf. ZILLES, Urbano. Filosofia da Religião, op. cit., p. 10.
} 
incapazes de fazer frente à complexa situação. Dessa forma, se buscaria evitar dois possíveis erros. O primeiro, na busca de defender a instituição, esquecer-se de que a sociedade de hoje é diferente do passado, tendo as Igrejas e cristãos a necessidade de se contextualizarem para apresentar a mensagem cristãs na atual realidade. $\mathrm{O}$ segundo, na busca de acomodar a instituição e seus princípios à atual sociedade, esquecer-se dos princíos inegociáveis intrinsecamente, e que não deveriam faltar à Tradição. Nessa tarefa, a Igreja não poderá perder de vista que, na tentativa de neutralizar o ateísmo advindo da secularização, deve-se tomar cuidado para não buscar neutralizar movimentos socioculturais interpretados como se fossem baseados na negação a Deus. E sobretudo, deve valorizar os aspectos do mundo secularizado que possam servir à maturação religiosa, sendo este o melhor antídoto contra os germes do ateísmo, caso contrário, o remédio pode ser pior que o próprio mal. ${ }^{287}$

Outra atitude errada seria apelar à fidelidade à fé, fechando-se ao mundo secularizado, impedindo o conhecimento adequado do mesmo, recusando-se a dar reposta às questões impostas pela secularização. Igualmente errôena e ver nesse processo só o poder do pecado, isto é, do ser humano desejar ser semelhante a Deus, negando assim o mundo em sua integralidade, apenas prevendo o caos para o futuro. ${ }^{288}$

Retornar ao mundo pré-secularizado não é só impossível, como também indesejável. No entanto, buscar respostas a este mundo em nome de uma contextualização da fé cristã que deve ser identificada com o mesmo, sem nenhuma reflexão ou reserva, cancela por completo o verdadeiro fundamento da fé em nome de um cristiansimo irreligioso tranformando o conteúdo da fé numa antropologia puramente imanentista, reduzindo a fé cristã à um postulado que qualquer um pode dizer. ${ }^{289}$

O mundo deve ser entendido como à disposição dos seres humanos, que em sua liberdade dará ao mesmo a configuração de suas mãos. O dilema surgido entre secularização e fé poderia ter sido contornado no início, se os representantes desta fé não colocassem a secularização em chave de oposição com o cristiansimo. Dando a impressão que o cristianismo negasse a auto-suficiência do mundo,

\footnotetext{
${ }^{287}$ Cf. GRUMELLY, Antonio. Dimensão sociológica. In: op. cit., p. 43-44; 47.

${ }^{288}$ Cf. FRIES, Heinrich, op. cit., p. 85.

${ }^{289}$ Cf. Ibid., p. 87.
} 
impedindo as pessoas de exercitarem domínio sobre o mesmo. Domínio que só seria possível apenas passando da secularização para o secularismo. No entanto, a correlação da tese da criação com a secularização não deve justificar aos proponentes da fé um triunfalismo, mas levar à adequada vivencia desta fé num mundo de secularização e, certamente, rejeitando o seculariamo. Ao mesmo, tempo afirmando que uma secularização legítima se constitui na medida que é suscetível à abertura à transcedência, e que admita a distinção entre Deus e o mundo. Onde o sentido e significado desse mundo não podem ser resolvidos pelas formas puramente imanentes. ${ }^{290}$

Fries declara que Karl Rahner é esclarecedor, ao perceber que tanto alguns aspectos advindos da secularização, quanto as formas errônas do teísmo, podem encontrar espaço em qualquer coração humano, produzindo hibridismo na vida pessoal com efeitos múltiplos. Tal fenômeno pede empenho à pastoral cristã, que será crucial na tentativa de superação deste desafio. ${ }^{291}$

\section{3 \\ Respostas e interpelações às implicações teológico-pastorais}

Para uma adequada fé cristã na sociedade moderna, faz-se necessário interpelar e responder as implicações teológico-pastorais advindas do processo de secularização do Ocidente. Objetivo que se utilizará das reflexões e da teologia de Hans Küng. Este teólogo será crucial, por seu conhecimento da relação do cristianismo com Modernidade.

\subsection{1}

\section{Contributos à ciência versus religião: abertura dialógica}

A superação do dualismo entre ciência e religião, constitui-se em possibilitar uma abertura dialógica. Para esta contribuição será necessário abordar: 1) resposta ao ateísmo da ciência evolucionista; 2) criação versus evolução: proposta de superação.

1) Resposta ao ateísmo da ciência evolucionista. O percurso desta réplica deve esclarecer: a) as questões fundamentais entre ciência e religião; b) os limites

\footnotetext{
${ }^{290}$ Cf. Ibid., p. 87-89.

${ }^{291}$ Cf. RAHNER, Karl. Considerações teológicas. Dimensão sociológica. In: Ibid., p. 65-84.
} 
da ciência moderna; c) qual é o principio de todas as coisas?; d) Deus: ao menos como hipótese; e) ciência e os milagres.

a) As questões fundamentais entre ciência e religião. Küng em sua avaliação afirma que a filosofia, a teologia como as ciências naturais possuem dificuldades com as mudanças da imagem do mundo, e estas mesmas áreas do saber não podem por si mesmas resolver esta enorme dificuldade, o que somente será possível com mútua colaboração. E hoje, essa realidade se torna possível já que foram eliminados muitos obstáculos, mal-entendidos e arrogância por ambos os lados. Hoje, pode existir uma colaboração razoável, crítico-dialógica entre teologia e ciências naturais proporcionando um melhor olhar sobre o mundo e o ser humano. Sendo necessário, por parte da teologia, abandonar a imagem do mundo medieval e aceitar a imagem do mundo moderno, avançando em direção a um novo paradigma teológico que permitirá solucionar os problemas teológicos, éticos, pastorais e sociais ainda pendentes. ${ }^{292}$

b) Os limites da ciência moderna. A ciência moderna exalta a razão. No entanto, os ser humano não vive exclusivamente da razão. Logicamente, foi legítimo o uso da razão para buscar solucionar as dúvidas humanas em relação à existência. Porém, a ciência deveria, de forma sistemática e imparcial, analisar a natureza com suas leis, o próprio humano e as relações sociais em seus múltiplos aspectos. Porém, apesar da legitimidade teórica, da necessidade histórica da racionalidade autônoma e do conhecimento científico, essa racionalidade com seu método, sua clareza, precisão e matematização dos problemas é questionável quando se pretende captar e racionalizar todas as complexas dimensões humanas de sentimentos, dentre outras, emoções e paixões, pois estas fogem a sua mensuração, não podendo os métodos científico-matemáticos pretender exclusividade sobre o espírito humano. Os métodos e a ciência não devem ser um fim em si mesmo, mas meios para atingir a humanização do homem, não podendo nenhuma ciência, como também a teologia, se converterem em um saber único pretendendo a universalidade. Deve sim, pretendendo ser ciência, atuar racionalmente, isto é, criticamente e com responsabilidade intelectual. ${ }^{293}$

Os proponentes das ciências naturais, mesmo pretendendo elevar seus conhecimentos à certeza matemática, necessitam compreender os limites das

\footnotetext{
${ }^{292}$ Cf. KÜNG. Hans. O princípio de todas as coisas, op. cit., p. 143-172.

${ }^{293}$ Cf. Ibid., p. 178-180.
} 
mesmas. Deve-se delimitar tanto os enunciados físico-matemáticos, como os metafísico-teológicos. As ciências naturais, mesmo sendo legítimas em seu método e princípio, não podem absolutizar seus resultados, devendo constatar que não existe um critério científico-matemático que permita afirmar que os enunciados metafísico-teológicos carecem de sentido ou são pseudoproblemas. Mesmo sendo a base da civilização moderna, as ciências naturais não podem abarcar o todo desta mesma civilização. E a ciência moderna pretendendo ser honesta a seu método, deveria prescindir de Deus, pois o mesmo não pode ser como os demais objetos, isto é, não pode ser constatado e analisado empiricamente. Muitos cientistas já assumem que por cima do âmbito de conhecimentos da ciência natural há uma pergunta mais ampla: a pergunta metafísica pelos problemas da vida - Wittgenstein, da cosmologia - Popper, do mundo -Kuhn. ${ }^{294}$

Os cientistas deveriam não se limitar ao seu estreito campo de visão, podendo sentir-se desafiados pela questão da religião. A integridade intelectual é mais importante que a conformidade dogmática, valendo este enunciado tanto para a autoridade eclesiástica ou secular. ${ }^{295}$

Buscando descobrir a origem e o sentido do universo, duas perguntas devem ser norteadoras. A primeira, sobre o ser do universo: por que existe o universo? Porque não existe o nada? A segunda, sobre a maneira do universo: por que o universo é da forma que é? Por que possui propriedades decisivas para nossa vida e sobrevivência? Para Küng, a história universal não pode ser apenas entendida como a história da humanidade - algumas centenas de milhares de anos - mas como uma história do mundo - desde sua explosão inicial há 13,7 bilhões de anos. $^{296}$

No entanto, este modelo-padrão de explicação - numa surpreendente descrição exata para o surgimento do universo pela atual ciência - não responde todas as perguntas da existência, da constituição, do desenvolvimento e futuro do cosmos. O "acaso" é necessariamente associado a essa ciência. Aliado a isso, a impossibilidade de uma superteoria irrefutável, uma fórmula mundial buscando explicar todos os mistérios do universo - pretensão da comunidade científica -

\footnotetext{
${ }^{294}$ Cf. Ibid., p. 180-183.

${ }^{295}$ Cf. Ibid., p. 8-10.

${ }^{296}$ Cf. Ibid., p. 14-15. Küng utiliza os termos "cosmos" e "universo" como sinônimos nesta obra.
} 
onde Deus se tornaria supérfluo. Tal concepção, possui sua motivação ideológica, pretendendo desvendar o que "sustenta o mundo por dentro", como Stephen Hawking tentou explicar com sua presunçosa e irônica "Grande Teoria Unificada" (GUT), que alegara ser capaz de "conhecer o espírito de Deus"297, isto é, "uma teoria de todas as coisas", onde o mundo se explicaria por si mesmo, descartando a possibilidade da liberdade de Deus para estabelecer as condições iniciais e as leis do universo, como poderia ser atribuído na antiga teoria da explosão inicial. ${ }^{298}$

Também a matemática, de mãos dadas com a física, e ambas em crescimento retilíneo e constante, não pode pretender universalidade, pois não é irrefutável e isenta de contradições, sendo essas mesmas limitações aplicadas aos programas de computadores, que pretendem cálculos de natureza universalizante. A pretensão de universalidade pelos proponentes das ciências deve-se ao fato de estarem presos ao paradigma positivista, que já deveria ter sido superado. O homem não pode abranger tudo, não poderá por constatação científica ultrapassar os limites do seu próprio horizonte cósmico; no máximo, ao que parece, poderá consegui-lo por meio da especulação. ${ }^{299}$

c) Qual é o principio de todas as coisas? Küng aponta que os cientistas não se simpatizam pelo que é único e singular. As leis físicas se caracterizam não pela singularidade, mas pela repetição, apesar de em muitos casos a singularidade ter sido resolvida. No entanto, a singularidade inicial da criação não pode ser conhecida a partir das leis posteriores à explosão primordial, isto é, o ponto 0 (zero) da criação perturba os cientistas. Como a ciência poderia explicar que em uma minúscula unidade que originou a explosão primordial, estaria contido todo o potencial de cem bilhões de galáxias? Somente após essa explicação é que se poderá explanar sobre as peculiaridades do universo. Então, não seria a empreitada dessa explicação um envolvimento com algo meta-físico ou protofísico? O big bang não é o começo, não é o primeiro momento individual (o primeiro "centésimo de segundo"), o início absoluto. Também "não pode ser um início dentro do tempo do mundo, ou dentro no tempo, mas sem o qual o tempo do mundo ou o mundo no tempo não pode ser explicado." ${ }^{300}$. Esse início, que

\footnotetext{
${ }^{297}$ Originalmente "to know the mind of GOD", no entanto Küng prefere traduzir "mind" (plano) por "espírito", devido à fraqueza do primeiro termo.

${ }^{298}$ Cf. Ibid., p. 28; 30; 31-34.

${ }^{299}$ Cf. Ibid., p. 37-42; 44; 68.

${ }^{300}$ Ibid., p. 71.
} 
ultrapassa o tempo e o espaço pode ser expresso pelo termo "origem", que não pode ser de antemão identificada com criação ou criador. Após Kant, não sendo possível apelar às provas da existência de Deus nem às provas contrárias, é lamentável a existência das falsas batalhas entre fé em Deus e ciência, e entre teologia e ateísmo, e ainda hoje a presença da ridicularização da religião por parte de cientistas $^{301}$ com seus frágeis e desconexos argumentos, que nem de longe conseguem se aproximam da originalidade e profundidade de seus antecessores clássicos. $\mathrm{O}$ ateísmo pode até ser compreensível, porém desnecessário. ${ }^{302}$

De onde vêm as leis da ordem cósmica? De onde veio a bola de fogo primordial de alta densidade da qual surgiu a explosão inicial? O que provocou esta explosão? E de onde veio a energia para essa explosão? O que estabeleceu as condições para que o universo se configurasse no que é? Em suma: de onde veio a estrutura mínima que já existia? Não há resposta dos cientistas ${ }^{303}$, e muitos fazem rodeios apelando a sentimentos, sem argumentos científicos e racionais ${ }^{304}$, argumentos que eles alegam existir na religião - não significa que tenhamos que apelar a Deus devido à lacuna do conhecimento, mas isso pode tratar-se de um convite para reflexão das condições iniciais, também para os cientistas. ${ }^{305}$

O caráter misterioso do mundo não desapareceu, dando a impressão de que quanto mais se avança em desvendar esses enigmas, menos claro e mais misterioso ele se torna tanto em nível micro, como em nível macrocosmo.

\footnotetext{
${ }^{301}$ Nesta seção menciona-se: Stephen Hawking, Carl Sagan, Francis Crick, Richard Dawkins, Jacques Monod e Peter Atkins.

${ }_{302}$ Cf. Ibid., p. 69-76; 81 .

${ }^{303}$ Küng explana sobre as inconclusivas especulações cosmológicas -muitas fantasiosas - sobre a possibilidade da existência de múltiplos universos (Cf. Ibid., p. 93-101), e que muitos físicos já rejeitam como sem sentido a pergunta sobre o que existe fora do universo, presumindo que exista um "fora" do "todo" (Cf. Ibid., p. 97). Küng não vê objeções a um multiverso, "pois um Deu infinito não é de forma nenhuma limitado em sua infinitude por um universo infinito, nem por vários universos" (Ibid., p. 99), mas opõe-se às hipóteses puramente especulativas, conforme recentes especulações dos economistas dos EUA, perguntando: "iremos então, para evitar uma meta-física, admitir uma 'física de bolhas'?" (Ibid., p. 99), esta física de bolhas refere-se às especulações de Andrej Linde, da Universidade de Standford. Küng também compartilha da ideia de que uma prova física para existência de Deus não pode ser qualificada para emitir este juízo, e invoca como coerente as "reservas de muitos físicos, de que nenhuma lei física pode implicar na existência de um verdadeiro infinito"; vê "uma aplicação da ideia básica de Kant, de que fora da experiência espaço-temporal a razão teórica deixa de ser competente, não podendo, portanto, em absoluto concluir de uma realidade finita para um infinito real" (Ibid., p. 104).

${ }^{304} \mathrm{O}$ que pode ser observado conforme exposto pelo prêmio Nobel de física, 1964, Charles Townes, que constata que existe uma "oposição instintiva" em relação à hipótese que não se encaixa em seus modelos explicativos (Cf. Ibid., p. 92-93), principalmente as que possam se identificar de alguma forma com o livro do Gênesis, ignorando assim a questão de Deus, principalmente para se coadunarem com o ateísmo científico por razão de politicamente correto, como a "teoria física de um universo inteiramente fechado em si, sem margens nem limites, sem começo nem fim - é o que, sem qualquer fundamento empírico, foi postulado por Stephen Hawking" (Ibid., p. 105). Quando não nos deparamos com uma ciência identificada como uma resignada profissão ateísta de que o homem e o mundo não tem sentido (Cf. Ibid., 109).

${ }^{305}$ Cf. Ibid., p. 88-93.
} 
Principalmente quando se pergunta por que existe o ser e não o nada, isto é, o mistério primordial da realidade, a pergunta por uma possível razão primeira e última deve ser posta a todos na busca de resposta e interpretação do sentido de toda realidade. ${ }^{306}$

d) Deus: ao menos como hipótese. Para Küng, os cientistas deveriam reconhecer Deus, ao menos como hipótese, baseado na afirmação de Werner Heisenberg, alegando que a causa da existência deve buscar fora do nosso mundo tridimensional $^{307}$, onde Deus como realidade responderia tanto a pergunta de por que não existe o nada, como as condições de contorno do cosmo configurando-o no que é. Mas como se poderia ter acesso ao mistério dos primórdios? Como consigo chegar à certeza de que Deus não se constitui apenas como hipótese ou ideia? Sobre essas questões, já ficou claro - devido à própria limitação das ciências naturais, dando razão a Kant - que as respostas às grandes questões da realidade e de seu sentido não podem ser respondidas no terreno da teoria pura, mas através da prática vivida e refletida. Não podem ser respondidas por operações teóricas da razão pura, nem por sentimentos irracionais e por puras emoções, mas se fundamentando numa decisão e atitude confiante e racionalmente responsável. Essa postura envolverá a experiência, o proceder e o agir de todo ser humano em sua complexidade. Atitude semelhante de quem deseja aprender a nadar e deve lançar-se nas águas misteriosas, ainda que necessite da ajuda de outros, não sendo possível alcançar este objetivo permanecendo em pé na margem, lendo um manual. O critério de verificação é indireto, buscando perceber Deus na realidade vivida do homem e do mundo, isto é em toda a integralidade da existência. Essa verificação sendo exercida pela experiência é acessível a todos, podendo tornar-se clara e expressa em palavras. E mesmo diante de um esclarecimento, não deixa de ser problemática. Porém, não dispensa o ser humano de uma decisão livre. Somente dessa forma, e com ela a transmissão adequada dessa experiência, é que o falar de Deus terá

\footnotetext{
${ }^{306}$ Cf. Ibid., p. 109-10; 116-17.

${ }^{307}$ Küng entende que o universo provavelmente seja finito -conforme a grande maioria dos cientistas - demonstrando o caráter finito e transitório das criaturas e do mundo. No entanto, um admitindo um universo infinito, isso não excluiria do cosmo o Deus infinito, mais confirmaria um puro espírito que tudo penetra por sum infinitude, isto é, a fé em Deus pode ser conciliada com diferentes modelos do mundo, acrescentando-se a isso que nem o início do tempo, nem sua duração infinita podem ser imaginados por não se encontrarem dentro do horizonte da nossa experiência (Cf. Ibid., p. 118).
} 
fundamentação para merecer fé. ${ }^{308}$ É esclarecedor observar a citação de Rupert Riedl:

Mesmo o ateu, o mecanicista e o monista dos nossos dias não precisam senão deslocar a pergunta pelas causas deste mundo para antes da explosão inicial, para terem que, com toda nossa ciência, eles se encontram na mesma desorientação com que, talvez incessantemente, tenham ridicularizado o culto do urso das cavernas. Ninguém ousa afirmar, pode pensar sem que se envolva com premissas metafísicas. É verdade que se pode não ter consciência delas. Mas não se pode dar um mínimo passo em direção ao desconhecido sem que nos envolvamos em expectativas de natureza metafísica, que se encontram além daquilo que conhecemos. A fé e seus rebentos, religião, filosofia, e visão do mundo, são indispensáveis a toda e qualquer cultura. - A fé é a moldura insubstituível para o que não tem explicação. ${ }^{309}$

e) A ciência e os milagres. Abordando uma temática de extrema polêmica, Küng pergunta sobre o que devemos pensar a respeito da rejeição dos cientistas pelos milagres - como violação das leis naturais - descritos na Bíblia Hebraica como no Novo Testamento. Embasado na crítica histórica e literária da Bíblia, alega que os milagres narrados não podem ser historicamente comprovados, cabendo o ônus da prova a quem diz o contrário. Entende que na narrativa dos milagres a ênfase não deve ser dada na ocorrência, mas na interpretação tanto da forma quanto do conteúdo, onde as narrativas não querem transmitir conhecimento, mas sim levar ao arrebatamento, interpretando a fé e anunciando a bondade de Deus. Küng salienta que na Bíblia, em parte alguma exige fé nos milagres, tanto no passado como na existência dos mesmos hoje. Os milagres são metáforas que apontam para a mensagem e o poder de Deus - aqui se exige fé que se dirige aos seres humanos, envolvendo-se com eles e com a história do mundo - dando um sentido à existência - sem, no entanto, violar as leis naturais, podendo os milagres e a imagens bíblicas serem interpretados dentro de uma visão evolucionista do mundo. Para Küng, com essa compreensão, a fé pode ser apresentada àqueles para os quais os milagres constituem um obstáculo à fé. $\mathrm{Na}$ concepção tradicional de milagres, Deus, como Senhor e Rei, dirige e controla os

\footnotetext{
${ }^{308}$ Cf. Ibid., p. 120. Aqui, pode-se imaginar que, com certeza, não faltam críticas à Hans Küng: estaria ele abrindo mão de fundamentos da fé cristã para coaduná-la com a o pensamento científico? Ou realmente necessitamos aceitar os fundamentos de Küng para apresentar a verdade bíblica? Uma coisa é certa, a postura de Hans permite uma aproximação para o diálogo com as mentes críticas dos proponentes da visão materialista, científica e evolucionista do mundo.

${ }^{309}$ Ibid., p. 200. Küng cita este trecho de: RIEDL, Rupert. Die Strategie de Genesis: naturgeschichte der realen welt. Munique, 1976, p. 294.
} 
acontecimentos. Essa compreensão leva, consequentemente, ao questionamento pelos desperdícios e becos sem saídas da evolução, como extinção ou animais e humanos que morreram lamentavelmente, e do infinito mal que se manifestou na história deste mundo. Para esse beco, a teologia, com a visão tradicional dos milagres, não tem resposta. Deus como espírito coaduna com a visão evolucionária do mundo. O Espírito infinito de Deus atua no finito, não de cima para baixo ou de fora para dentro, agindo de dentro perpassando-o e completandoo, sendo origem, meio e fim do processo do mundo, continuadamente respeitando as leis da natureza mesmo nos processos mais dolorosos. ${ }^{310}$ Logo, não está em jogo “ou o mundo ou Deus. Nem o mundo sem Deus (ateísmo), nem Deus identificado com o mundo (panteísmo)! Mas Deus no mundo, e o mundo em Deus" 311 .

2) Criação versus evolução: propostas para superação. Hans Küng apresenta cinco passos para superação do debate entre criação e evolução. Passos que demonstram a necessidade da teologia desvencilhar-se do paradigma medieval e inserir em seu contexto um novo paradigma. Em suas propostas, apresenta alguns conceitos sobre Deus que podem coadunar com a concepção científica evolucionista. Podendo superar os obstáculos entre estas esferas, e tornar a concepção do Deus cristão inteligível às mentes reflexivas e questionadoras do modo tradicional de falar sobre Deus.

a) Um novo pensar e falar sobre Deus: o primeiro passo. A rejeição da realidade de Deus, na verdade se refere à rejeição da caricatura de Deus feita pela esfera religiosa e pelas atrocidades cometidas em seu nome. Então, como pensar em Deus adequadamente? Para Küng, falar de Deus deve ser feito de uma forma cautelosa e nova. Até porque muitos cientistas acreditam na existência de uma realidade transcendente, no entanto, possuindo dificuldades em compreender o Deus bíblico caricaturado. Algumas ideias de Deus precisam ser recusadas: a) Deus não pode ser identificado com o cosmos, não é um ser intraterrestre, não é deste mundo, não pode ser constatado empiricamente. No entanto, isso não significa que ele não é pai ou mãe num sentido humano; b) Deus não é um ser

\footnotetext{
${ }^{310} \mathrm{Cf}$. KÜNG, Hans. O princípio de todas as coisas, op. cit., p. 207-214.

${ }^{311}$ Ibid., p. 215.
} 
supraterreno, antropomórfico habitando um céu físico acima do mundo; c) Deus não é um ser extraterrestre habitando um céu metafísico. ${ }^{312}$

Para pensar e falar de Deus, principalmente à consciência científica atual, precisamos ter em mente o espaço temporal envolvido de eternidade $\mathrm{e}$ imensurabilidade numa concepção que coaduna com a moderna compreensão unificada e dinâmica da realidade: a) Deus está neste universo e este universo está em Deus, ao mesmo tempo em que Deus é maior que o mundo, ainda que houvesse outros universos; b) Deus está presente em toda parte, sendo imanente ao mundo, perpassando o universo e atuando sobre ele. Tem parte no seu destino, participando dos seus processos e do seu sofrer; c) Deus transcende o mundo perpassando e superando o universo, sendo infinito e não estático. Logo, Deus é inapreensível e sua relação com o homem só pode ser formulada dialeticamente: transcendência na imanência. ${ }^{313}$

b) Deus, mais do que pessoa: o segundo passo. No entanto, apesar de Deus ser inapreensível, ao mesmo tempo pode ser chamado de pessoa? Küng propõe romper com o conceito tradicional de Deus, entendido no sentido atual do termo "pessoa".

Em primeiro lugar, Deus é mais do que pessoa, rompendo este conceito humano. Deus não é um super-homem, um super-eu. Esta proposta supera a noção demasiadamente humana, isto é, antropomórfica do teísmo sobre a noção de Deus. A noção de Deus como pessoa não é aceita pelo budismo, como em outras concepções orientais, onde seus pensadores se referem ao "uno", ao "nirvana", ao "vazio", ao "nada", como uma expressão paradoxal que não pode ser presa em conceitos e ideias. Em segundo lugar, Deus não é menos do que pessoa, e pelo fato de não ser coisa, ele não é compreensível - como na tradição oriental -, sendo aquele que torna possível o vir-a-ser da pessoa. Deus também não é impessoal,

\footnotetext{
${ }^{312}$ Cf. Ibid., p. 149-150. Küng salienta: "Einstein não teria tido tantas dificuldades em aceitar a teoria quântica se não tivesse identificado Deus com a natureza, ou com as leis naturais, como seu 'filósofo doméstico' Espinoza" (Ibid., p. 149). E continua: "também esta ideia iluminista e deísta está superada: Deus não é nenhum interlocutor 'fora' do mundo, existente, objetificado, coisificado, no sentido espiritual ou metafísico, num além, num 'mundo oculto"' (Ibid., p. 150).

313 "Em sua infinitude ele envolve todos os seres, todas as estruturas e processos finitos. É a realidade dos seres, todas as estruturas e processos finitos. É a realidade transempírica a que tudo é referido e que tudo abrange" (Ibid., p. 150). "Sua realidade envolve o tempo. Não é uma realidade sem tempo, mas antes uma eternidade contemporânea de todas as partes do tempo. Deus não é uma realidade imutável do bem (Platão), sem relação com a historicidade do homem e do mundo. Também não é um 'motor imóvel' (Aristóteles), nem um uno primordial sem vida (Plotino). Não é nenhum mago que aplique truques. Não, Deus é o próprio dinamismo, ele cria o mundo em si mesmo, sustenta-o e move-o invisivelmente a partir de dentro" ( Ibid., p. 151).
} 
não é uma razão universal ou consciência anônima, Deus é a suprema e última realidade, porém, não é indiferente ao homem e nem nos deixa indiferente. Ao mesmo tempo em que é onipresente ao mesmo tempo nos é subtraído. É o Deus escondido, no entanto, próximo e envolvido com o povo e com o indivíduo, conforme na Bíblia Hebraica. ${ }^{314}$

c) Deus criador: o terceiro passo. Deus pode culturalmente ser expresso por conceitos e imagens antropomórficas, como na Bíblia. Um desses conceitos é o "Deus Criador". Esta compreensão é o terceiro passo para superação da controvérsia criação versus evolução.

No sentido bíblico, a criação significa que "o Deus único" fez existir todos os seres e o cosmos Nas religiões, a narração do surgimento do mundo indica que o mundo não é um fim em si mesmo, mas situando a vida dentro de uma ordem cósmica em harmonia com o mundo. Para uma compreensão bíblica, é necessário ater-se no que os relatos da criação acentuam de maneira única. No caso do primeiro relato, denominado sacerdotal $(\mathrm{P})$, conforme Gênesis $1,2-2,4^{315}$ a ênfase se encontra: a) na transcendência de Deus; b) na dignidade do homem; c) na ordem da criação. Aqui não se fala da criação do nada, mas uma criação a partir do caos, sendo Deus a origem de todo vir-a-ser, incluindo o caos ${ }^{316}$ original, conservando o todo na existência e na vida. A narração não é em ordem cronológica, mas numa estrutura poética, organizada em seis dias onde tudo era bom. No segundo relato da criação, javista $(\mathrm{J})$, conforme Gênesis 2,4b-25, por sua vez enfatiza: a) dá-se a organização do que ainda não havia sido organizado; b) ênfase na criação do primeiro casal e não como, mas sim no gênero "homem e mulher", esta, auxiliando ao homem e não se submetendo à ele. Ambos com espírito e corpo à imagem de Deus; c) "submeter a terra" não significa explorar, mas sim cuidar; d) onde "dominar" sobre os animais significa ser responsável por eles; e) e dar-lhes nomes significa familiarizar-se com seu ser. No entanto, a criação a partir do nada - creatio ex nihilo - não é mencionada, sendo apenas desenvolvida muito mais tarde nas comunidades judaicas sobre a influência do

\footnotetext{
${ }^{314}$ Cf. Ibid., p.146-152.

${ }^{315}$ Este relato eloísta, no entanto, foi escrito depois do segundo relato (Gênesis, 2,4b-25), este alguns séculos antes foi escrito ou redigido por volta de 900 a.C, é chamado de javista (J).

${ }^{316}$ "Chaos, em grego, significa originalmente o espaço vazio, a massa primordial informe; já na atual linguagem cotidiana ele tem o significado confusão. Em física, no entanto o caos significa um sistema complexo hipersensível, como o que se manifesta, por exemplo na meteorologia, onde causas extremamente pequenas podem provocar grandes efeitos" (Ibid., p. 196).
} 
helenismo, aparecendo pela primeira vez no $2^{\circ}$ livro dos Macabeus que trata dos anos 175-135 a.C. ${ }^{317}$ Então, "criar do nada" significa na realidade:

Uma expressão filosófico-teológica para o fato de mundo e homem, juntamente com espaço e tempo, serem devidos unicamente a Deus, e a nenhuma outra causa... Deus mesmo não se deve a causa nenhuma (...) Nem sequer podemos chamar Deus de 'causa sui - causa dele mesmo' (Descartes, Spinoza). Pois de forma alguma ele é causado....É - por definição - a realidade incausada, porque eterna e perfeita..... ${ }^{318}$

d) A linguagem e a harmonização bíblica: o quarto passo. A Bíblia apresenta uma linguagem metafórica e uma evolução da ideia de Deus. Nela existe uma constante, que se constitui na possibilidade do ser humano falar com Deus. No entanto, para Küng, a Bíblia não deve ser reconhecida como palavra por palavra citada diretamente por Deus, mas como a sua palavra na palavra dos homens. Para uma compreensão adequada a crítica bíblica, quando exercida com seriedade, não apenas possível, mas necessária e indispensável para que a comunicação de Deus não se encerre na Bíblia e no passado. Esta compreensão permitirá que a mensagem seja sempre revivida e reanunciada, devendo ser compreendida como relato de diversificados "testemunhos de fé", e não simplesmente a revelação de Deus. Sendo entendida como testemunho humano da Revelação em seu próprio 'Sitz im Leben'. Desta forma, respondeu aos questionamentos de ontem e, continua respondendo, aos de hoje sobre a origem e essência do mundo e do ser humano. ${ }^{319}$

Com relação à harmonização bíblica, não se deve harmonizar nem misturar a linguagem bíblica com a científica. A Bíblia não descreve os fenômenos científicos, mas interpreta-os para nosso viver e agir humano do presente. Para evitar mal entendidos do passado, estas duas linguagens devem ser separadas claramente. Desta forma, a linguagem bíblica e a visão científica do mundo não estão em contradição, mas também não é possível harmonizá-las. Não é o núcleo do que é científico que deve ser demonstrado pela Bíblia, mas sim o que é indispensável para a fé e a vida. A existência ou não-existência de Deus não é atributo da ciência, mas sim o universo físico, deixando espaço para o que não pode ser explicado fisicamente, e neste âmbito é a Bíblia que tem a palavra. No

\footnotetext{
${ }^{317}$ Cf. Ibid., p. 155-164.

${ }^{318}$ Ibid., p. 170.

${ }^{319}$ Cf. Ibid., p. 165-166.
} 
entanto, a ciência não pode confirmar ou refutar a clara mensagem bíblica dos dois relatos do Gênesis: no princípio do mundo está Deus, não dizendo, portanto, que no princípio houve a explosão, mas sim alegando que se fez energia, matéria, espaço e tempo. Para Küng, a teologia cristã insiste na criação do nada e na criação continuada que inclui o surgimento de novas estruturas, devendo ambas serem vistas como uma unidade. ${ }^{320}$

e) A síntese: o quinto passo. A síntese para superação permitirá a fé na criação, mesmo diante dos argumentos científicos. Küng sintetiza sua ideia que permitira compreender a criação numa perspectiva existencial: a) no início existia apenas o bom Deus; b) e toda sua obra criadora era boa, incluindo a matéria, o corpo e a sexualidade etc.; c) o objetivo da criação é o ser humano dentro do cosmo, sendo alvo da bondade de Deus desde a criação; d) o mundo não é Deus e em si, não é santo, mas está à disposição do homem; e) o mundo é ordenado e não um caos, e pode ser utilizado, cultivado e pesquisado pelas mentes. Esta fé na criação permite um saber de orientação, proporcionando descobrir um sentido na vida e no processo de evolução, transmitindo padrões para ação e uma segurança na vastidão do universo. Estas questões não podem ser respondidas pela ciência natural, mas, é respondida por uma razoável confiança que os cristãos chamam de fé, que aponta para o Deus eterno que antecede todo o tempo. No entanto, ninguém é obrigado a abraçar esta fé, mas aceitando-a em liberdade os seres humanos mudarão a forma de pensar e agir no mundo criado pela plenitude da luz, que habita numa luz inacessível, e como luz, irradia para o cosmo a força que ilumina, aquece e cura. ${ }^{321}$

Estabelecido os passos para superação da luta de braço de ferro entre criação e evolução, a fé na criação pelos parâmetros estabelecidos permitirá levar em consideração: a) a questão do início da vida do cosmos, permitindo entender que a narração dos seres humanos em Gênesis não permite uma interpretação literal, criação, do paraíso, da queda e da origem da humanidade a partir de um casal; b) pelo menos, ao que se refere ao cosmos e ao corpo do ser humano, deve ser admitido um processo de desenvolvimento natural, para a vida na terra há cerca de 3,5 bilhões de anos, e para o homem há cerca de 200 mil anos; c) a origem da vida, sobretudo o espírito do ser humano, é fruto de uma intervenção direta de um

\footnotetext{
${ }^{320}$ Cf. Ibid., p. 166-169; 171.

${ }^{321}$ Cf. Ibid., p. 171-177.
} 
ato criador; c) ainda que não haja conhecimento exato de como a vida veio surgir do material sem vida, porém, as explicações da transição para vida baseiam-se nas leis da bioquímica, enquanto, os princípios da seleção natural e da sobrevivência dos mais aptos promovem evolução às formas mais elevadas em processos de extremas complexidades, mas não se pode concluir que tenha tido uma intervenção especial do Deus criador, sendo possível ser entendido como um processo físico-químico; d) o acaso ou necessidade, indeterminação ou determinação, o materialismo ou idealismo não possuem um explicação "totalmente" persuasiva para explicar a evolução, como também, não devo postular a existência de Deus pelo fato da ciência não possuir uma explicação "totalmente" convincente para o surgimento da vida; e) qualquer explanação plausível, por sua vez, não descarta a possibilidade da existência de Deus; f) pela fé judaico-cristã, a evolução carece de conferir sentido existencial ao homem, o que parece não transmitir esperança ou racionalidade. ${ }^{322}$

Küng salienta que, a religião e a ciência possuem suas razões, autonomia e leis próprias, no entanto, podem se completar. Enquanto a religião vê a evolução como criação, a ciência a vê como um processo concreto; a religião atribui um sentido à evolução, enquanto a ciência não deduz esta realidade, no máximo pode suspeitar. $^{323}$

\subsection{2}

\section{Contributos à razão versus fé: o ser humano e Deus}

A superação desta segunda chave de oposição, razão versus fé, se faz urgente devido à extensão e o alcance desse dualismo, configurando um agravamento em relação à primeira chave de oposição apresentada. Este agravamento se dá pelas forças das narrativas que o sustenta, parecendo atingir o ser humano em suas raízes ontológicas.

1) Resposta à Feuerbach e aos mestres da suspeita. Küng os considera como os grandes ateus da humanidade: Feuerbach, Marx, Nietzsche e Freud. Um dos motivos para esta alegação é o fato de suas críticas à existência de Deus e a religião mesclarem-se com argumentos sólidos, que se fundamentavam no conceito equivocado de Deus e do cristianismo, e na práxis cristã que realmente

\footnotetext{
${ }^{322}$ Cf. Ibid., p. 178-199.

${ }^{323}$ Cf. Ibid., p. 206.
} 
não coadunava com os registros bíblicos, mas se apresentavam como errôneas e dignas de críticas.

a) Ludwig Feuerbach. Postulando uma crítica antropológica da religião que não ser pode superestimada e nem subestimada. Feuerbach em sua última fase é mais que um crítico da religião, é um filósofo da religião, devendo sua crítica ser discutida com seriedade, mesmo tendo falhado em vários prognósticos, incluindo o fim do cristianismo. A fundamentação do seu ateísmo em razões psicológicas, alegando ser Deus um produto psicológico da mente humana, certamente, foi o efeito mais duradouro de suas conclusões que atribui à experiência religiosa um desejo de Deus. Küng admite que em todo conhecimento que opere a imaginação, conhecendo pessoas e coisas a sua maneira e projetando algo de si mesmo. No entanto, isso não comprova que este objeto signifique apenas uma projeção. Mesmo diante de tal operação, este objeto não se torna irreal quando é real, o mesmo se pode dizer sobre o conhecimento e experiência de Deus, da mesma forma que minha experiência psicológica do mundo nada diz contra a existência do mundo independente de mim. A experiência psicológica de Deus pode responder a algo real, o mesmo pode ser afirmado em relação ao desejo de Deus. O que faz desta conclusão de Feuerbach apenas um postulado. Mesmo não fundamentado cientificamente, mas intuitivamente, o ateísmo de Feuerbach não pode ser ignorado, mas demonstra o quanto das operações psicológicas podem estar presentes no conceito de Deus. E demonstram a necessidade de superar as debilidades dos discursos excessivamente ingênuos e antropomórficos, e os marasmos dos discursos filosóficos e especulativos sobre Deus. ${ }^{324}$

b) Karl Marx. Desenvolve o seu ateísmo sociopolítico enfatizando o materialismo dialético e o socialismo materialista. O último Marx pode ser entendido também como humanista. Na esteira de Feuerbach, Deus para Marx é também projeção da mente humana, e a religião se configura como projeção e alienação, como também, ópio do povo. A alienação religiosa deveria ser superada pela práxis das relações sociais concretas. Para Marx e seus seguidores, sua proposta ateísta sociopolítica deveria se configurar como a visão de mundo para sociedade. Porém, Küng afirma que tanto o ateísmo de Marx, quanto suas críticas à religião carecem de fundamentos convincentes. Pelo mesmo fato - como

\footnotetext{
${ }^{324}$ Cf. KÜNG, Hans ¿Existe Dios?, op. cit., p. 288-289; 294-304.
} 
a crítica à Feuerbach - de que a religião utilizada como ideologia em diferentes esferas não pode ser utilizada como negação da realidade da existência de Deus. Küng salienta que Marx é mais um revolucionário utópico do que um cientista analítico da realidade, sendo mais um profeta de suas pressuposições do que fundamentador científico das mesmas, principalmente no seu prognóstico de uma sociedade socialista sem religião. Entretanto não se pode ignorar Marx. Mesmo não estando o seu ateísmo fundamentado, de forma alguma isso liquida a sua crítica à religião, que continua valendo para hoje. Quando a religião torna-se exclusivamente criação humana e Deus - insondável em sua realidade -, torna-se apenas produto de projeção da mente. $\mathrm{O}$ mesmo pode-se dizer da utilização da religião para os mais perversos fins ideológicos, fatos presentes na história das religiões e, infelizmente, realidade ${ }^{325}$ que se entende até nossos dias. E o que dizer se pode um cristão ser socialista. Para Küng, o cristão não deve ser impedido de aderir a uma concepção política, apesar de não ser coerente identificar-se com ela em todos os seus aspectos, pois os sistemas políticos podem, além de possuir ambiguidades, possuir aspectos que devem ser rejeitados à luz da Bíblia pelos cristãos. Porém, o cristão deve se envolver a sério com a justiça social, sem ver forçosamente a salvação com socialização no seu sentido estrito. Marxistas e cristãos podem mutuamente chegar a certo grau de entendimento para uma construção crítica e frutífera da sociedade. Porém, a verdadeira e última autoridade para o cristão não vem de Marx, mas de Cristo. ${ }^{326}$

c) Friedrich Nietzsche. Com sua crítica contra os teólogos e contra a razão segura de si mesmo, possui também uma postura cética em relação à ideia de progresso do século XIX. Prioriza o instinto da vida humana, dentro da concepção darwinista. Provocando com suas concepções o cristianismo, a cultura europeia e os proponentes dos costumes desta civilização. Utilizando para estas críticas, a esteira da pessimista cosmovisão de Schopenhauer. Apesar das múltiplas interpretações dadas a Nietzsche, devido ao fato que em sua própria obra pode se ver declarações contraditórias e a possibilidade de projetar a ele diversos pensamentos. Küng esclarece ser necessário confessar que o desafio do nihilismo deve ser aceito. A urgência em confrontar a postura de Nietzsche se legitima pela

\footnotetext{
${ }^{325}$ Não só a religião esta sujeita a esta realidade, mas também o próprio socialismo ateu e o ateísmo, conforme comprova a história, com suas atrocidades.

${ }^{326}$ Cf. Ibid., p. 305-364.
} 
capacidade de sua crítica gerar uma crise dos fundamentos de uma metafísica ingênua. Não sendo possível apelar como escapatória para os seus deslizes, nem pela suposição de seu ateísmo não fundamentado. Não sendo razoável desconsiderar suas demais críticas pela impossibilidade de provar a concepção cíclica do seu mito do eterno retorno, do mito do seu super-homem ou pela falha de seu prognóstico da morte de Deus. Não pode ser desprezado pelo fato, apesar da paixão de Nietzsche pela verdade, de suas verdades serem muito frequentemente meias verdades. E muito menos por suas críticas não possuírem força com o modo de ser do cristianismo neotestamentário, mas sim com as expressões equivocada das Igrejas cristãs e seus fiéis. Porém, mesmo com todas as possibilidades de refutação à Nietzsche, todos os religiosos e Igrejas podem aprender com as graves acusações de Nietzsche. Dentre suas críticas, pode-se salientar: a) a necessidade de superar a hierarquia absolutista e inflexível, a vontade de poder, os modos dominadores antidemocráticos das instituições cristãs e suas imposições à sociedade e aos sacerdotes; b) o perigo das igrejas e seus sacerdotes dominarem as almas dos homens utilizando-se de ideologias semelhantes a do Estado; c) a urgência do cristão testemunhar o evangelho pela práxis e não apenas pela pregação; d) a necessidade das igrejas investirem cada vez mais esforços para valorizar o ser humano em sua totalidade: espiritualidade, corporeidade, sexualidade em conformidade com a essência do cristianismo; e) rever o conceito do Deus cristão conforme pregado e vivido por Jesus de Nazaré. Desta forma, a mensagem do evangelho se mostrará não como alienação da realidade, mas como veículo de liberdade e verdade para humanização dos seres humanos e desta forma, superar a radicalidade provocativa de Nietzsche e as consequências alarmantes do nihilismo individual e social. Sendo estas modalidades de nihilismo tanto irrefutável quanto indemonstrável, não havendo argumento racional demonstrando a sua impossibilidade, como não há nenhum argumento racional que o justifique. ${ }^{327}$

d) Sigmund Freud, o pai da psicanálise, nascido em 1856, numa época onde se imaginava que o mundo se explicava por si mesmo, pelas interações entre os materiais e suas forças, incluindo o espírito humano, sendo Deus considerado supérfluo e a religião, no máximo, era questão privada. Sobretudo, por causa dos

\footnotetext{
${ }^{327}$ Cf. Ibid., p. 470-578.
} 
avanços da anatomia e da físiologia - sendo preponderante o Darwinismo - que favoreceram o materialismo da medicina e fomentou o ateísmo da segunda metade do século XIX.

Ao aplicar seus postulados à religião, Freud apresenta duas questões interrelacionadas: a origem da religião e sua essência. Acreditava que a origem da religião é uma questão meramente psicológica. Assumindo a explicação etnológica da religião de sua época e o esquema evolutivo dos primeiros clássicos da história da religião, fundamenta a tese que os ritos religiosos assemelham-se às ações neuróticas compulsivas ${ }^{328}$. Considerava a religião como uma neurose compulsiva universal, onde Deus é o pai biológico sublimado e raiz da necessidade da religião. No entanto, Freud tirava suas conclusões de sua visão psicanalítica global e de suas experiências clínicas que apontavam para o Complexo de Édipo. Logo, as ideias religiosas que inexoravelmente deveriam desaparecer, não são merecedoras de crédito. Ideias que para Freud não podem ser provadas ao mesmo tempo em que não podem ser refutadas. Sendo estas ideias, desejos que são frutos do desamparo infantil do homem e da humanidade diante dos perigos externos ou nascidos no próprio íntimo. Para Freud, a religião é uma fase de transição por qual o homem passa até chegar ao amadurecimento racional, por isso deve-se tentar uma educação arreligiosa, educando o homem e a humanidade para realidade. A religião em Freud pode constituir-se no maior adversário à visão científica do mundo, mesmo Freud possuindo certas reservas em relação a alguns postulados científicos. Suas conclusões, apesar de estarem presas dentro do esquema mental da época e apresentadas como hipótese, visão, suposição e tentativas, são criticadas por etnólogos e cientistas da religião. Estes alegam que as conclusões de Freud não são plausíveis por ele ter apenas se preocupado com a sua natureza psicológica, e não com o seu teor de verdade. ${ }^{329}$

Muitos postulados de Freud foram criticados por outros dois astros da "psicologia do profundo",330, Adler e Jung. No entanto, a pesquisa destes três, principalmente concernente ao inconsciente, possibilitou uma decisiva e profunda mudança na visão da realidade humana em diversas esferas do conhecimento. ${ }^{331}$

\footnotetext{
${ }^{328}$ Organizadas em artigos quatro em Totem e tabu ,1912.

${ }^{329}$ Cf. KÜNG, Hans. Freud e a questão da religião. São Paulo: Verus, 2005, p. 13-48.

${ }^{330}$ Deve-se esta expressão ao psiquiatra de Zurique, Eugen Bleuler, professor de Jung.

${ }^{331}$ Cf. Ibid., p. 48-76.
} 
Küng destaca quatro críticas à Freud que devem ser levadas em consideração: a) ele teria exagerado na sua abordagem da libido atuando este em todas as coisas. Sendo concretamente muito difícil dar esta universalidade à sexualidade, quanto esta sexualidade na fantasia dos sonhos. Quanto a essa questão, Küng afirma: "nem tudo quando é esquecido é reprimido, nem todo lapso possui um sentido oculto. Os sonhos estão longe de ser sempre realizações de desejos insatisfeitos" ${ }^{332}$. Sendo esclarecedor, no caso das pesquisas de Freud, que a "transferência de teorias científicas, fisiológicas e de mecânica cerebral de um aparato reflexo, depara-se com seus limites quando estão em jogo as necessidades

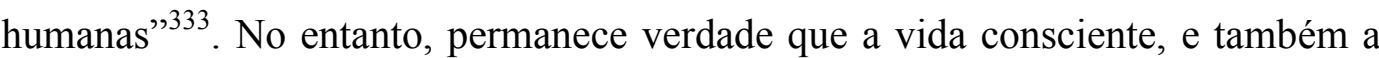
vida religiosa, continua sendo afetada por experiências e lembranças passadas, incluindo a sexualidade. E esta, sendo perturbada pode influenciar negativamente proporcionando uma religiosidade degenerada, podendo até ser onipresente e violenta, quando não integrada harmonicamente na estrutura da personalidade; b) Freud teria supervalorizado as experiências da primeira infância e fatores ambientais em relação aos fatores inatos. Küng faz as seguintes elucidações: 1) os traumas da infância não podem ser supervalorizados e os conflitos da puberdade subestimados, pois ambos são decisivos para a personalidade adulta; 2) os sonhos não se relacionam apenas com o passado, mas preponderantemente com a atualidade. Contudo, as experiências da primeira infância certamente podem influenciar a pessoa por toda a vida sem que disso a mesma tome consciência; c) as perturbações sexuais podem ter origem em motivos não sexuais. Tanto a livre atividade sexual quanto o próprio tratamento psicanalítico pode levar consequências negativas às pessoas. Küng esclarece: 1) concretamente se objeta que a terapia freudiana não deve ser considerada o único meio para superação dos conflitos psíquicos, devendo ser levadas em consideração metas positivas, éticas e religiosas; 2) deve-se apelar também à consciência, à responsabilidade e a vontade do paciente, devendo a orientação não ser apenas retrospectiva, mas também prospectiva, onde a religião poderá ser de extrema relevância; 3) não se pode abrir mão para uma educação no tocante a sexualidade, condição importante, principalmente para a ética. É preciso uma orientação para uma solução amadurecida, que abra caminho para um novo desenvolvimento e utilização plena

\footnotetext{
${ }^{332}$ Ibid., p. 85 .

${ }^{333}$ Ibid., p. 85.
} 
das forças vitais; d) o Complexo de Édipo no homem, correspondente ao complexo de castração na mulher. Porém não foram comprovados universalmente, apesar das tentativas no âmbito clínico, ontogênico ou filogenético. Küng salienta que a ligação incestuosa aos pais como fenômeno de ocorrência normal na infância não pode ser provado, nem por etnólogos e nem por psicólogos. Sendo preponderantemente maiores para o surgimento de neuroses, as condições adversas tanto na família quanto na sociedade. Não podendo ser generalizadas as fixações de relações infantis incestuosas como uma forma grosseira de sexo. No entanto, sendo de importância crucial para o desenvolvimento humano, os relacionamentos afetivos contraídos na primeira infância, que poderá afetar positivamente ou negativamente. Não podendo se esquecer de que o complexo de Édipo para muitos psicólogos é considerado um mito. Küng, no entanto, declara que depois de desmitificado, este complexo exprime uma realidade: a relação do recém-nascido - a fase edipiana, do segundo ao sexto ano de vida - com sua mãe ou substituta, refere-se a um círculo fechado que se abre com o surgimento da percepção de uma terceira pessoa, o pai, podendo acarretar conflitos que poderão ser preponderantes. Onde as experiências desta fase não são dominadas, como praticamente uma regra, os sintomas neuróticos se apresentarão mais tarde. Chame esta realidade Complexo de Édipo, ou não. ${ }^{334}$

Feuerbach e os mestres da suspeita, Marx, Nietzsche e Freud com suas teorias e posturas críticas à religião, mesmo não sendo capazes de provar que a religião e a crença em Deus fossem projeção da mente e desejo, ópio e alienação, ou neurose. Suas críticas às formas errôneas, imaturas e até neuróticas da religião e da crença, ainda hoje, possuem lugar na contemporaneidade. Sendo necessário aos proponentes das expressões religiosas sempre avaliarem a própria fundamentação e legitimidade.

\subsection{3}

\section{Resposta à repressão da religião e da expressão religiosa}

Em nossos dias é de crucial importância confrontar a repressão da religião e das expressões religiosas na psicologia, na psiquiatria e na psicoterapia. Para

\footnotetext{
${ }^{334}$ Cf. Ibid., p. 85-90.
} 
Küng, pode haver mútuo esclarecimento entre estas e a teologia, entre os especialistas e os teólogos. É necessário ser reconsiderado o tradicional confronto destas ciências com a religião, onde esta é sempre um objeto de estudo e a religiosidade apenas uma deformação doentia passiva de terapia. É imprescindível cautela de ambos os lados, para não apresentar a religiosidade unicamente como patologia e nem desconsiderar possíveis desvios patológicos presente na mesma, quando esta não é autêntica.

Estas áreas atribuem a toda forma de religião a incapacidade de ser construtiva para autocompreensão do ser humano. Nesta postura, não reconhecem a possibilidade que o conhecimento dos fenômenos religiosos pode proporcionar para auxiliar a autocompreensão dos profíssionais destas áreas, em relação aos pacientes que aderem a alguma forma ao religioso. No entanto, Küng alega que há outros que pensam diferentes. Como teólogo, abertamente declara que dá preferência para profissionais conscientes de que a religião não pode ser eliminada do horizonte do exercício desta profissão, devendo ser levada a sério. Os profissionais das áreas em questão, não se devem enquadrar a religiosidade como patologia, mas devendo as convicções psicológicas ser compreendidas psicologicamente. Neste contexto, Küng levanta o seguinte questionamento: não deveriam os psiquiatras e os profissionais acadêmicos, se questionarem se não estariam manifestando um fenômeno de repressão da religião, e que deveria ser levado a sério ${ }^{335}$

As convicções religiosas, segundo Freud, são o mais antigos, intensos e urgentes desejos da humanidade que são satisfeitos, ainda que ilusoriamente, através da religião. E o segredo da força da religião é a força desses desejos. Logo Küng questiona: a repressão desses desejos por estas áreas do saber, além de outras, não poderiam acarretar consequências destrutivas? Para Küng, uma forma moderna de repressão seria a realização humana em formas puramente seculares, como a profissão, a política, o engajamento social e o esporte. No entanto, estas realizações atingem áreas parciais da vida humana. Porém, a religião interpela o ser humano pelo sentido da sua vida e do mundo, que não pode ser respondida por experiências parciais da vida, e não podendo ser função do superego. Valendo ressaltar: a neurose característica do nosso tempo não seria a sexualidade

\footnotetext{
${ }^{335}$ Cf. Ibid., p. 101-108.
} 
reprimida, mas a falta de orientação, normas, sentido e o vazio existencial que sofrem inúmeras pessoas da nossa época. Küng questiona: não seria isso a causa de dependências químicas, criminalidade, niilismo prático, terrorismo, o anarquismo terrorista e suicídio, que apontariam para o descompromisso éticoreligioso que caracteriza o modo pós-moderno de ser? ${ }^{336}$

Küng enfatiza a necessidade por parte dos profissionais mencionados, buscar por terapias mais humanas sem repressão mútua por parte da religião e da psiquiatria. Tendo em mente o mútuo desafio de orientar os seres humanos em sua integralidade. Desta forma, deve-se advogar o respeito e não marginalização da religião por parte da psiquiatria, psicologia e da psicanálise. Porém, sem advogar uma psicoterapia religiosa, mas sim, uma terapia que leve a sério o fenômeno da religião, não se restringindo a perguntar, apenas, pela confissão religiosa do paciente, mas pela integralidade do seu relacionamento com a religião do coração. Deve-se lembrar que não há retorno depois de Freud. E independentemente de determinadas teorias freudianas terem sido refutadas, não se pode, até agora objetar que:

A partir de Freud tudo o que é humano, ou seja, toda atividade consciente individual e social do homem, inclusive sua religião e sua fé em Deus, tem que ser visto necessariamente em conexão com aquela região da psique que possui suas leis próprias e que, não obstante, se subtrai ao controle consciente e á observação direta $-\mathrm{o}$ inconsciente, o estranho profundo do homem. ${ }^{337}$

Os teólogos muito têm a aprender com Freud, para que possam discernir o desequilíbrio da própria religião e religiosidade, e aprofundarem o conhecimento do próprio ser humano no mundo, buscando mais emancipação e liberdade amadurecida para os mesmos. No entanto, são patentes a limitações da própria psicanálise:

Pode, na verdade, remover sentimentos neuróticos de culpa, mas não pode libertar da culpa real. Pode remover doenças psicossomáticas, mas não pode responder às perguntas essenciais sobre o sentido e o não-sentido, sobre o viver e o morrer. Sua meta é o conscientizar, não o perdoar, é a cura, não a salvação. ${ }^{338}$

\footnotetext{
${ }^{336}$ Cf. Ibid., p. 114-117.

${ }^{337}$ Ibid., p. $76-77$.

${ }^{338}$ Ibid., p. 84.
} 


\title{
4.4 \\ Interpelação aos modos de críticas pós-modernos
}

Os modos pós-modernos de crítica caracterizam-se por não apresentarem nenhuma fonte de orientação à existência e, por descartar a religião como detentora de sentido, possuindo, além destes aspectos, convicções normalmente ateístas, tudo atacam, mas não oferecem alternativa. Esta corrente, por não apresentar propostas à pergunta fundamental para os seres humanos: qual a causa primeira e o sentido último do homem e do universo? No entanto, os "profetas pós-modernos da falta de sentido" reconhecem que estamos numa época de desorientação, sendo esta, também um reflexo da falta de sentido e desconfiança de tudo que apresente como tendo sentido.

Uma postura adequada e moderadora para condição humana na atual sociedade secular e pós-moderna, deve considerar o sentido da vida em seu aspecto mais amplo: a postura de equilíbrio não deve ser de "contramodernidade, nem de ultramodernidade, mas de superação da modernidade."339 Küng apresenta a seguinte consideração:

\begin{abstract}
Não pode se contentar-se com um pluralismo radical ou um relativismo ("verdade, justiça, humanidade no plural”, assim em referência a J-F. Lyotard, W. Welsch), pois essas são características da modernidade tardia desintegrada. A arbitrariedade, a diversidade, a mistura de tudo e de todos, a anarquia das linhas de pensamento e estilos, o "anything goes" metodológico, a concepção moral do "tudo é permitido", essas e outras coisas semelhantes não podem ser identificadas como o rosto da pósmodernidade. Caso isso seja realidade, justifica-se a crítica conservadora à modernidade (ex.: a crítica de R. Spaemann). ${ }^{340}$
\end{abstract}

Hoje, não se deve conceber um antimodernismo religioso genérico, nem um anti-iluminismo programático. Estas modalidades não colaboram para superação da crise hodierna. A nossa época deve ser considerada a partir do atual paradigma pós-moderno, e sob a luz de um novo macroparadigma. Levando em consideração a possibilidade de sobrevivência de qualquer sociedade democrática e pluralista. $^{341}$

O paradigma da modernidade deve ser superado pelo novo macroparadigma, que deve ser entendido como pós-modernidade. Não devendo

\footnotetext{
${ }^{339}$ KÜNG, Hans. Projeto de ética mundial, op. cit., p. 48.

${ }^{340}$ Ibid., p. $48-49$.

${ }^{341}$ Cf. Ibid., p. 50-53.
} 
ser confundido com contentamento com o pluralismo radical, ou com o relativismo. Este macroparadigma emerge se constituindo devido à nova constelação que está se esboçando: a) geopolicimente configura-se não uma hegemonia mundial centrada nos países europeus, mas uma constelação policentrista de diversas regiões do mundo; b) política externa, pós-colonialista e pós-imperialista; c) econômica, pós-capitalista e pós-socialista configurando-se numa economia ecossocial de mercado; d) político-social, uma sociedade pósindustrial, onde os países desenvolvidos cada vez mais oferecerão prestação de serviços e de comunicações; d) relações sociais, pós-patriarcal tendendo a mútuo entendimento entre homem e mulher; e) político-cultural, pós-ideológica tendendo a uma cultura pluralista e integral; f) político-religiosa, pós-confessional e interreligiosa, com muita dificuldade, podendo desenvolver uma comunidade mundial multiconfessional e ecumênica. ${ }^{342}$

Küng denomina a época atual, a pós-moderna, como uma comunidade global com grande possibilidade de diálogo entre religiões, confissões e regiões, que chegou a um alto grau de inabitabilidade desencadeada pelo desenvolvimento moderno. ${ }^{343}$ Esta época é vista por Küng com otimismo.

\section{5}

\section{Contributos ao ser cristão e suas instituições}

A busca da superação das problematizações advindas deste horizonte é crucial, para a vivência e perpetuação tanto das instituições cristãs, quanto das expressões da fé em seu nível individual, para o exercício adequado de suas respectivas missões.

1) A Igreja Católica: contextualização institucional e relacional. A Igreja Católica Romana, que na época do Concílio do Vaticano II gozava de grande prestígio público, adentra o terceiro milênio atacada em alguns setores da sociedade e convivendo com crises internas. Situações que problematizam a questão da adesão de novos membros na atual sociedade secularizada.

Para superar estas dificuldades, e continuar perpetuando sua missão de anúncio e novas adesões ao reino de Deus, Hans Küng sugere a necessidade de

\footnotetext{
${ }^{342}$ Cf. Ibid., p. 45-49.

${ }^{343}$ Cf. KÜNG, Hans. Teología para la postmodernidad: Fundamentación ecuménica. Madrid: Alianza Editorial, 1989, (T.N), p. 17.
} 
democratização das estruturas da Igreja, abrindo-se às propostas de mudanças emitidas por críticos e pessoas inseridas em sua própria fileira. Küng propõe algumas posturas que deveriam ser superadas, e assim superar também as problematizações que se encontram diante da Igreja. Apresentamos, dentre elas: a) a postura de não ordenação às mulheres, quanto à proibição de contraceptivos; b) a obrigação à vida celibatária; c) a Infabilidade Papal. ${ }^{344}$ Outro movimento urgente promovido pela Igreja para maior sustentabilidade e perpetuação da sua missão, deve buscar: a) enfatizar o que é essencial na teoria e na prática; b) superar o êxodo do ministério eclesiástico; c) incentivar e promover vocações no seio da nova geração; d) fortalecer a disciplina, principalmente do culto dominical, entre os fiéis e eclesiásticos; e) buscar a superação das crises, principalmente nos países anglo-saxões, de escolas católicas, revistas, editoras e associações; f) buscar e perpetuar uma constante inspiração para solucionar de forma construtiva os problemas atuais; g) fomentar cada vez mais uma liderança espiritual em Roma, entre os bispos, e que esta liderança seja também intelectual e inspiradora. $^{345}$

Küng vislumbra uma Igreja para atualidade e futuro voltada às suas origens e presente, apresentando e representando a flexibilização necessária aos novos tempos. Para viver e proclamar tais características, a Igreja deve nutrir e perpetuar em sua essência: a) o ecumenismo e abertura; b) a universalidade, a parceira e hospitaleira transparente e convidativa. Onde todos possam exercer seus dons, e sintam-se autenticamente como pessoas, e contentes em servirem à sua comunidade em liberdade e amor. ${ }^{346}$

Imbuída deste espírito, a Igreja continuará a ser exemplo pelo seu próprio ser para os cristãos. E suas afirmações poderão ser cada vez mais eficazes, podendo recrutar as mentes e os corações para compreensão e adesão de sua missão, dialogando com a atual sociedade e fazendo sua mensagem do reino de Deus inteligível, não apenas aos cristãos, mas para toda humanidade e expressões religiosas.

2) A senda protestante: da imersão na secularidade ao equilíbrio. É necessário que a senda protestante se reoriente algumas de suas atitudes,

\footnotetext{
${ }^{344}$ Cf. KÜNG, Hans. A Igreja Católica, op. cit., p. 19-24.

${ }^{345}$ Cf. Id., O que deve permanecer na igreja. Petrópolis: Vozes, 1976, p. 15-17.

${ }^{346}$ Cf. Id., Para que um ethos mundial?, op. cit., p. 143-144.
} 
principalmente a vertente pentecostal e neopentecostal, devendo superar uma religião ou religiosidade que possui alguns aspectos: a) não junta, mas separa; b) constrói suas próprias redes de sociabilidade; c) não unifica, mas cria espaços separados formando ilhas de sentido, apresentando múltiplos e às vezes irreconciliáveis sentidos à sociedade; d) cria um abismo entre religião e nação; e) cada religioso se encontra em desencantos e desentendimentos que o fazem aderir uma nova religiosidade; d) esta forma de religião não possui mais a idade dos séculos, a idade do encontro com a transcendência, mas possui idade adolescente; e) uma religiosidade, onde cada vez mais segue se aproximando à relação de consumo nas regras do mercado, passando o fiel a ser seu consumidor. Entretanto, consumo religioso não implica necessariamente em conversão, mas uma prática à procura de socorro mágico-religioso que agrega diversas crenças e tradições, e esta prática se escondem em diversas camadas sociais. Porém, estas formas de religiosidade - que se desenvolvem mais rapidamente nas camadas sociais menos desfavorecidas - são realizadas sobre a insinuação que a "oferta financeira" moverá o mundo espiritual a favor da pessoa, parecendo um contrassenso o fato de que aqueles que não têm como se sustentar dignamente, devam pagar por uma coisa cujo acesso deveria ser de graça, isto é, a religião. ${ }^{347}$

Como se observa, o principal ponto de superação desta imersão ao secular constitui-se na concepção da religião utilitária e triunfalista, necessitando de ser interpelada na busca de uma religiosidade autêntica.

a) Interpelação a religião utilitarista e triunfalista. A grande dificuldade destes movimentos se encontra em não conhecer, reconhecer ou aceitar uma adequada hermenêutica bíblica, seja qual for o motivo do pano de fundo para tal compreensão: interesse próprio (financeiro, agrado das massas), a projeção da qual falava Feuerbach, a alienação identificada por Marx ou a aplicação das teorias freudianas.

Para esclarecer os equívocos destas interpretações, salientado que, a vivência da fé cristã triunfa não só pelo que é vencido, mas triunfa também diante da derrota. A verdadeira fé que permite confrontar e superar a concretude da vida, mesmo diante da dúvida e da incerteza, na insegurança atormentadora ou na segurança absoluta, no fracasso ou sucesso, no temor ou na esperança, diante da

${ }^{347}$ Cf. PIERUCCI, Antônio Flávio; PRANDI, Reginaldo. A realidade social das religiões no Brasil. São Paulo: HUCITEC, 1996, p. 260-261; 266; 272-273. 
consciência do pecado ou da graça perdoadora, até mesmo diante da morte. Esta fé reconhece que independente do que esteja sendo vivenciado, Deus continua sendo bondoso, misericordioso, justo e amor. ${ }^{348}$

A postura da fé cristã é antagônica à trama capitalista, à concorrência e ao individualismo como práxis. O comportamento cristão deve se fundamentar no ensino e nas ações de Jesus de Nazaré, onde encontrará o modelo de vida, transformando-a, vivendo-a em autenticidade e de forma humanizadora, tanto na individualidade quanto em comunidade. Esta fé pode aspirar em oferecer uma proposta concreta de orientação básica para toda sociedade, apresentando um novo caminho, um novo estilo, e um novo sentido a vida.

Em Jesus de Nazaré encontramos uma verdadeira postura diante da concretude da vida. Postura que oferece e possibilita viver sobre uma nova orientação:

\begin{abstract}
Uma nova orientação e atitude fundamental, uma nova abordagem à vida, que Jesus convida indicando suas consequências. $\mathrm{O}$ indivíduo ou a comunidade que aceitam Jesus Cristo como padrão e modelo para as suas relações com os homens, com o mundo e com Deus podem viver de forma diferente, mais autêntica e humana. Ele faz possível uma identidade e uma coerência interna na vida. ${ }^{349}$
\end{abstract}

Novas motivações:

Motivos novos para atuar, que podem ser tomados da "teoria" e "práxis" de Jesus. A partir dele é possível dá uma resposta à pergunta de por que o homem deverá agir por seu exemplo e não o contrário, por que devemos amar, não odiar, por que - e a isto não poderia responder o próprio Freud - deve ser honesto, que perdoa e bondoso quanto possível, mesmo quando isso o prejudique e o desprezo e brutalidade dos outros o fazem de objeto de seus golpes. ${ }^{350}$

Novas disposições:

Novas e estáveis convicções, tendências e intenções, adotadas e mantidas no espírito de Jesus Cristo. Produzindo disponibilidade, criando atitudes e comunicando possibilidades que são capazes de dirigir o comportamento, e não apenas em momentos isolados e passageiros, mas sim de maneira durável. Tais disposições visam o compromisso humilde em favor do próximo, a solidariedade com os despossuídos, a luta contra estruturas injustas; disposições de gratidão, liberdade, generosidade, abnegação, alegria, mas também de indulgência, perdão e

\footnotetext{
${ }^{348}$ Cf. Id., ¿Existe Dios? op. cit., p. 824-825.

${ }^{349}$ KÜNG, Hans. Ser Cristiano, op. cit., p. 699.

${ }^{350}$ Ibid., p. 699-700.
} 
serviço; disposições que se mantêm também nas situações-limite, a doação total de si, na renuncia não necessária, e a entrega a causas nobres. ${ }^{351}$

Novas ações:

Novos fatos de maior ou menor alcance, que se realizam em seguir Cristo, só que precisamente ali onde ninguém ajuda, não apenas programas gerais para a transformação da sociedade, mas sinais, provas, testemunhos concretos de humanidade e da humanização do homem e da sociedade. ${ }^{352}$

Um novo sentido:

E uma nova meta na realidade última, a consumação do homem e da humanidade no reino de Deus, capazes de assumir não só o positivo, mas também o negativo da vida humana. A luz e a força de Jesus Cristo dá ao crente um sentido último não só para avida e ação, mas também para a dor e a morte do homem, e não só para tempos de sucesso, mas também para as horas dolorosas da humanidade. ${ }^{353}$

Este modelo remove o eclipse promovido pela concepção utilitarista e triunfalista da religião, descortinando a verdadeira fonte de transcendência, fonte de meditação e práxis cristã. Não obscurece a experiência do encontro com Deus e o fascínio que envolve o ato de fé diante do mistério. Sendo justamente deste encontro e fascínio com o Deus Transcendente, revelado e escondido, a causa primeira e última do pensar e do agir cristão.

A verdadeira religiosidade advoga o ideal de não escravizar, mas libertar; não prejudicar, mas curar; não desequilibrar, mas estabilizar. A religião, com seus ritos e símbolos, deve favorecer a individualidade oferecendo padrões éticos à sociedade, principalmente à juventude. Apesar da complexidade humana, deve permitir o desenvolvimento da identidade e da dignidade para superar as angústias e fundamentar a confiança, compreensão e respeito, amizade e amor. O cristianismo poderá favorecer, dentro deste aspecto global, a sensibilidade e emotividade, abrindo a consciência para um maior engajamento à humanização, verdadeira condição humana. ${ }^{354}$

\footnotetext{
${ }^{351}$ Ibid., p. 700.

${ }^{352}$ Ibid., p. 700.

${ }^{353}$ Ibid., p. 700. Principalmente pelo exemplo da cruz do Crucificado, que torna possível a superação do negativo, no entanto, superação com sentido. $\mathrm{O}$ crucificado nos ensina a não buscar a dor, mas suportá-la; não apenas suportar a dor, mas sim combatê-la; não só combater a dor, mas transformá-la. Numa atitude de liberdade diante da realidade, excluindo a ilusão da fuga do negativo, em atitude de superação (Cf. Ibid., p. 722-734).

${ }^{354} \mathrm{Cf}$. KÜNG, Hans. Freud e a questão da religião, op. cit., p. 127-131.
} 
Esta autêntica religiosidade fundamenta a importância da oração, proporcionando força em qualquer ocasião e momento da vida. A oração exprime que qualquer êxito é um dom e expressa gratidão, possibilitando pedir perdão pelos erros. Afinal, somos exortados a orar sem cessar, não significando a toda hora, mas apontando para a certeza de está em boas mãos, mantendo a esperança que apontam à realidade de outra dimensão da vida, a vertical, a transcendência pela qual somos sustentados. ${ }^{355}$

3) Superação da ruptura e descompasso. A interação entre a instituição cristã e seus fiéis deve estabelecer um consenso que busque equilíbrio, não só entre igreja e cristãos, mas também entre estes com os princípios neotestamentário.

a) Subjetividade: da imersão ao equilíbrio. A religião tem com sua doutrina, ritos e instituições um aspecto de subjetividade: a religiosidade e a experiência religiosa. No entanto, na compreensão cristã, uma espiritualidade equilibrada não pode ser fundamentada na emersão subjetiva, nem na erupção emotiva, mas deve fundamentar-se numa espiritualidade que possui em equilíbrio os fatores subjetivos e objetivos. Esta interação permitirá uma atitude básica que repercutirá numa postura integradora do ser cristão diante da história, da salvação, da ética, da sociedade e da cultura. Esta concretude da experiência cristã no mundo, não permitirá relativismo ou indiferentismo, mas um engajamento profundo em generosidade e altruísmo. No contexto destas experiências subjetivas, não é adequado generalizar suas coincidências, como também não é adequado difundir suas diferenças, nem absolutizar as experiências subjetivas por serem ambíguas. No entanto, apesar da ambiguidade das experiências religiosas, o cristianismo, pretende a verdade objetiva, absoluta, última e primeira, e não só a psicológicosubjetiva ou conceitual e abstrata. Para este propósito o cristianismo deve apresentar uma religiosidade que conduz às práticas e valores reais, para configurar a pessoa em sua humanidade, e que mantenha unida a experiência religiosa e reflexão sobre a mesma. ${ }^{356}$ Em síntese, Küng afirma:

Tanto o pragmatismo quanto o intelectualismo são apenas um aspecto da realidade religiosa: a experiência e reflexão devem estar unidas (...). Sem experiência religiosa, carece de conteúdo a reflexão sobre a mesma: a reflexão vive da

\footnotetext{
${ }^{355}$ Cf. Id., Para que um ethos mundial?, op. cit., p. 97-99.

${ }^{356}$ KÜNG, Hans ¿Existe Dios?, op. cit., p. 821-834.
} 
experiência (...). Sem reflexão religiosa, a experiência religiosa é cega: a experiência religiosa necessita de uma reflexão que a ilumine e lhe dê garantia crítica. ${ }^{357}$

b) Do "crer sem pertencer" ao "crer pertencendo". O comportamento do "crer sem pertencer", especificamente, emergindo da característica que se inseriu na mentalidade de uma sociedade plasmada pela escolha que, consequentemente, reflete no trânsito religioso, ainda que não signifique trânsito institucional e confessional de fato.

Deve ser acrescentado a este quadro crítico, que a pregação e práxis cristã poderá não agradar a todos, e desta forma, sempre haverá uma situação de poder verificar em outros arraiais aquilo que lhe apraz.

Será este um caminho sem volta? Ou poderão as Igrejas reverter ou amenizarem este quadro? O que poderíamos intuir em Küng para que as Igrejas cristãs, principalmente a Igreja Católica, possam confrontar esta situação e diminuir a possibilidade de evasão e falta de identificação entre fiéis e a Igreja? Além de possíveis contextualizações para aproximar a identificação dos fiéis em relação à Igreja, quais seriam as propostas mais específicas para este objetivo?

Em Küng percebemos as seguintes propostas para as Igrejas cristãs: a) proporcionar a vivência na comunidade de fé baseada em princípios não individualistas, mas comunitários, preservando e nutrindo o planejamento conjunto, interagindo fiéis e clero, para práxis das Igrejas. Favorecendo a realidade e o sentimento de plena comunhão e mútuo serviço, garantindo à comunidade e a cada cristão individualmente, a percepção de se constituir como um agente ativo, como membro do corpo de Cristo, proporcionando sentimento de acolhimento em sua expressão individual, sendo esta última a característica fundamental da sociedade hodierna; b) promover a comunhão norteada pelos princípios de igualdade, fraternidade e liberdade entre instituição e fiéis, e entre a própria comunidade; c) garantir que esta comunhão reconheça, preserve e nutra em prol da mensagem de Cristo e em amor, a pluriformidade em vez de uniformidade, tanto na pluralidade de constituições eclesiais, quanto na diversidade das estruturas comunitárias, que devem servir não a particularidades mas ao todo. No entanto, para concretizações destas propostas, deve apresentar as

\footnotetext{
${ }^{357}$ Ibid., p. 834.
} 
seguintes ideias norteadoras para própria instituição: a) evitar em suas fileiras, não só o tradicionalismo romântico como também o absolutismo político; b) observar a condição de transitoriedade da Igreja que, uma vez reconhecida, não permitirá que foquem ou se constituam em si mesmas, mas estejam centradas em Deus que irrompeu em Cristo, em torno do qual a Igrejas cristãs esperam a consumação crítica de sua própria missão. ${ }^{358}$

Desta forma, as Igrejas poderão perpetuar a fé, a tradição e o fortalecimento dos símbolos cristãos, possibilitando uma espiritualidade elaborada pela reflexão eclesial autêntica na comunhão do Espírito de Jesus Cristo, comunicando-a às gerações presentes e às vindouras, criando uma melhor condição e possibilidade para o "crer e pertencer".

\section{6}

\section{A proposta de orientação básica cristã para sociedade}

Por suas reflexões e práxis diante da concretude do real o cristianismo pode configurar como uma a possibilidade de apresentar uma proposta de orientação básica para atual sociedade secular.

A sociedade se encontra numa crise de orientação ampla e profunda. Desde 1960 as instituições guardiãs das tradições estão em crise ou estão sendo seriamente questionadas, principalmente pela juventude. Esta crise de orientação instalada num alcance inimaginável. Com a perda do poder regulador da religião e das instituições sobre a sociedade, perdeu-se também a moral e instalou-se o niilismo, previsto por Nietzsche. Küng afirma que a ética não pode ser fundamentada unicamente de forma racional - como desejava Freud. No entanto, muitas pessoas diante desta crise anseiam por uma base de orientação, que é diferente de regulamentos e prescrições. Deste fato, observa-se a possibilidade de abandono e solidão espiritual que acomete os mais jovens, enquanto os mais velhos se orientam a seus modos por formas simplistas como horóscopos, biorritmo, dietas, ioga, terapia de grupo e ação política. Enquanto manipula-se a energia nuclear e a genética demonstrando "os poderes do fazer" dos seres

\footnotetext{
${ }^{358}$ KÜNG, Hans. Ser Cristiano, op. cit., p. 610-642.
} 
humanos, por outro lado, não se sabe especificamente, qual seria a proposta para orientar esta sociedade. ${ }^{359}$

Três perguntas norteiam as propostas de Küng para este desafio de oferecer uma proposta de orientação para sociedade: por que precisamente uma orientação cristã? Onde encontrá-la? E o que ela significa na prática?

Por que precisamente uma orientação cristã? Inicialmente, Küng salienta três aspectos cruciais: a) a maioria dos nossos contemporâneos está convencida que diante da crise de valores e orientação, não poderá haver convivência humana sem o mínimo consenso sobre padrões de orientação; b) não se pode fundamentar uma ética apenas racionalmente, não podendo impunemente deixar a religião de lado, não existindo "ação moral, humana, incondicionalmente obrigatória, nem uma ética também incondicionalmente obrigatória, sem religião!” ${ }^{360}$ Esta função se não for assumida por uma religião verdadeira, será assumida por uma pseudoreligião ou simulacro de religião. Para religião, a autoridade incondicional não é condicionada pelo humano, mas provêm do Absoluto, de Deus; c) cristãos e nãocristãos devem reconhecer, que o cristianismo possui valores e normas favoráveis aos seres humanos, quando não manipulado. Estes valores e normas podem conduzir à felicidade, à dignidade, à liberdade, à justiça e solidariedade. A mensagem cristã não é somente teórica e abstrata, mas prática e concreta. ${ }^{361}$

No entanto, esta proposta, não significa voltar à Idade Média, mas guiarmonos por uma bússola segura. Küng justifica sua proposta, para que seja compreensível, diante dos protestos dos não-cristãos e dos que não possuem fé, não somente aos descrentes de fora, mas também aos descrentes de dentro. Em primeiro lugar, não podem ser consideradas como cristãs: a) todo dogmatismo autoritário e não inteligível; b) a moralidade estreita e distanciada da realidade; c) a arrogância, intolerância, oportunismo e legalismo; d) a piedade ineficaz de muitos que estão ligados à Igreja, em todas as suas esferas; e) a identificação e o amparo de governos tirânicos; f) as discriminações, inquisições, guerras e mortes em nome de Deus. Tudo isso não é cristão, cabendo uma crítica impiedosa. Estas posturas, não tem relação com Cristo, mas com interesses; não tem relação com a mensagem de Jesus de Nazaré. Muitas posturas foram pseudocristãs ou anticristãs.

\footnotetext{
${ }^{359}$ Cf. Id., Por que ainda ser cristão hoje? Campinas: Verus Editora, 2004, p. 11-16.

${ }^{360}$ Ibid., p. 18.

${ }^{361}$ Cf. Ibid., p. 17-19.
} 
Deve-se tomar todo cuidado para a fé em Cristo não apelar à outra autoridade que possa contradizer a mensagem cristã. Em segundo lugar, Küng apresenta os aspectos positivos do cristianismo para sociedade: a) seus valores e normas são intrinsecamente favoráveis à humanização dos seres humanos, possibilitando a convivência entre estes e, podendo conduzir às causas nobres e ao sentido da vida; b) o Deus da fé judaico-cristão é favorável à humanidade, podendo os seres humanos depositar a fé nele e dirigir-lhe a palavra; c) o Deus cristão pode ser percebido mesmo dentro da visão moderna do mundo; d) a orientação para o Deus verdadeiro não permite a pessoa escravizar-se às coisas deste mundo, mas que se expresse como ser humano com elas. ${ }^{362}$

Onde encontrar esta orientação? Sem segredo algum, esta orientação é encontrada na pessoa histórica de Jesus de Nazaré, autoridade para os cristãos, em todas as eras, em todas as coisas, que anunciou; viveu e revelou o Deus vivo que possui um rosto humano de Pai, no entanto, que também é mãe. O Deus bondoso e próximo aos seres humanos, não só exige, mas também dá; não humilha o homem, mas reergue-o, cura, poupa os que caem, liberta fazendo valer a graça com justiça. O Deus que é amor. Jesus de Nazaré, pela causa deste Deus, viveu e foi executado. Esta fé capacita o cristão a viver à medida de Jesus de Nazaré, que é seu Messias, o Cristo, a Imagem e filho de Deus. Jesus de Nazaré se constitui na medida última e confiável do que realmente significa o que é ser humano. ${ }^{363}$

O que significa a orientação básica cristã na prática? Küng salienta que Jesus é mais que um professor e mestre. Ele chama aos que desejam segui-lo, a assumir os seus ensinos e práticas não por imitação, mas por correlação, isto é, eu o sigo seguindo o meu próprio caminho, comprometendo-me e sendo orientado por Jesus. Não por força, nem por obrigação, nem por "ter que", mas sim, por "ter-oportunidade-de" viver um verdadeiro presente e uma autêntica graça na qual podemos fundamentar nosso pensar e agir. Um modelo que não tem como objetivo massagear almas, mas converter corações com mudança de mentalidade e mudança de condições de práxis, conduzindo a um novo sentido e a uma nova meta na realidade última, vivendo não apenas como humano, mas radicalmente humano ${ }^{364}$. Tratando-se de uma humanidade radical que é capaz de abraçar

\footnotetext{
${ }^{362}$ Cf. Ibid., p. 19-37.

${ }^{363}$ Cf. Ibid., p. 38.

${ }^{364}$ Cf. KÜNG, Hans. Ser Cristiano, op. cit., p. 701-759.
} 
positivamente a concretude da vida, incluindo o sofrimento e a luta, e tudo superar. $^{365}$

\section{7 \\ O estabelecimento do diálogo ecumênico e inter-religioso}

Não se pode prescindir do diálogo ecumênico e inter-religioso na busca de um ethos mundial de paz, justiça e convivência pacífica para o presente e futuro da humanidade. Este empenho poderá auxiliar na superação de intolerâncias, radicalizações e fundamentalismos que podem acometer a esfera religiosa.

As Igrejas cristãs devem buscar mútua colaboração, para formular uma teologia ecumênica para juntar e não separar. No entendimento mútuo tanto ad intra, isto é, interconfessional e intracristã, quanto ad extra, isto é, uma ecumene no âmbito mundial extra-eclesial e extracristã. Sendo necessária que esta formulação teológica intente para uma melhor missão da Igreja em nossa sociedade. O desenvolvimento de uma solução ecumênica deve admitir a necessidade de uma interpretação histórico-crítica da Escritura. No entanto, esta interpretação deve compreender a relatividade deste corte diante da leitura crítica. Devendo a inspiração bíblica ser entendida de acordo com o processo da história como testemunho da revelação. No entanto, deve existir um "sim" para a centralidade da Bíblia, para a Tradição e à autoridade eclesiástica, ao mesmo tempo em que deve existir um "não" para o biblicismo, para o tradicionalismo e ao autoritarismo. ${ }^{366}$

A centralidade da crença dos cristãos não deve ser a Igreja ou a Tradição, e por mais polêmica que pareça esta postura, Küng segue adiante e afirma esta mesma concepção em relação a Bíblia:

O cristão protestante não crê na Bíblia, mas naquela de quem ela dá testemunho (...) $\mathrm{O}$ cristão ortodoxo não crê na Tradição, mas naquele que ela transmite (...) O cristão católico não crê na Igreja, mas naquele que ela anuncia (...) Aquilo que merece a confiança incondicional do ser humano e no que ele pode apoiar-se no tempo e na eternidade, não são os textos bíblicos nem os Padres da Igreja e tampouco o magistério eclesiástico, mas o próprio Deus como ele se manifestou

\footnotetext{
${ }^{365}$ Cf. Id., Por que ainda ser cristã hoje?, op. cit., p. 45-52.

${ }^{366}$ Id., Teologia a caminho: fundamentação para o diálogo ecumênico. São Paulo: Paulinas, 1999, p. 66; 75-76; 80-82. Küng utiliza nesta obra, o raciocínio de: KUHN, Thomas. A estrutura das revoluções científicas. São Paulo: Perspectiva, 1978; onde Kuhn analisa o paradigma no processo de desenvolvimento das ciências. Küng utiliza destas reflexões transferindo-as para teologia, observando a necessidade de um novo paradigma.
} 
em Jesus Cristo. Os textos bíblicos, as afirmações dos Santos Padres e da autoridade eclesiástica - cada um em seu grau - apenas têm a finalidade de ser expressão dessa fé. ${ }^{367}$

É o próprio Jesus Cristo que constitui a força do Espírito na Bíblia, mantendo-a viva independentemente da limitação da nossa compreensão. Ele é o fundamento da fé que revela e nos faz crer em Deus Pai. Fé que pode ser experimentada em nossos dias pelo Espírito que inspira a Escritura. ${ }^{368}$

Uma teologia ecumênica deve-se fundamentar a partir do horizonte da experiência do mundo na atualidade. No entanto, criticamente baseada na mensagem cristã. Küng apresenta os seguintes critérios para fundamentação e estabelecimento desta teologia, que essencialmente há de ser:

1) "Católica", continuadamente preocupada com a "totalidade" e a "universalidade" da Igreja, e, ao mesmo tempo "evangélica", estritamente ligada à Escritura, ao Evangelho; (...) 2) "Tradicional", feita com responsabilidade histórica, e "contemporânea", encarando com seriedade os problemas do presente.(...) Além disso: 3) "Cristocêntrica", com diferencial decididamente cristão, e "ecumênica", aberta à oikumene, a todo o "mundo habitado", a todas as Igrejas, religiões e regiões. (...) 4) "Teórico-científica", dedicada à doutrina e à verdade, e, "prático-pastoral", preocupada com a vida, com a renovação e a reforma. ${ }^{369}$

O diálogo inter-religioso é condição prévia para paz entre as religiões e, consequentemente, entre as nações. Não podendo as religiões ficar centradas em si mesmas. Apesar dos antagonismos e paralelismos, das divergências e convergências, as religiões devem nutrir o diálogo crescente para entendimento mútuo. Mesmo diante das enormes dificuldades, esta é uma tarefa urgente e passos consideráveis têm sido alcançados, principalmente, entre o budismo e o cristianismo. $^{370}$

Em seu ensaio sobre uma criteriologia ecumênica, Küng salienta que as grandes religiões devem reconhecer a corresponsabilidade para elaboração da paz mundial, devendo existir para alcançar esta realidade a paz entre as religiões. A paz entre as Igrejas cristãs é condição para paz entre as religiões. O ecumenismo estabelecido no cristianismo deve ser considerado como parte integrante do

\footnotetext{
${ }^{367}$ Ibid., p. 83.

${ }^{368}$ Cf. Ibid., p. 83-84.

${ }^{369}$ Ibid., p. 199, sendo apresentada novamente na página 238 da referida obra de Küng.

${ }^{370}$ Cf. Ibid., p. 241-242.
} 
ecumenismo mundial. No entanto, é necessário perguntar se existe uma única religião verdadeira, porquanto a confrontação das grandes religiões não se reduz à questão da paz, mas também um esclarecimento sobre a verdade.

Küng apresenta quatro posições fundamentais sobre a religião, que devem ser recusadas: a) nenhuma é verdadeira, todas são falsas. Sendo esta a pretensão atéia; b) apenas uma é verdadeira. Todas as outras são falsas. Sendo a antiga pretensão católica romana, em relação à primazia e a veracidade do cristianismo sobre as demais religiões e confissões, sendo reavaliada no Vaticano II; c) todas são igualmente verdadeiras. Quem conhece de perto todas as religiões não faria esta afirmação; d) só uma pode ser verdadeira e as demais podem participar $^{371}$ da verdade da religião única. Apesar de parecer uma postura tolerante revela-se como uma forma de dominação por inclusão. ${ }^{372}$

Então, qual seria a proposta sobre a delicada questão da verdade nas religiões? Para Küng, nenhuma religião pode pretender o monopólio da verdade, e nem renunciá-la em nome de um pluralismo convencional. De antemão, é necessário verificar a fronteira entre verdade e falsidade na própria religião que se adere, para depois poder avaliar as demais, não podendo renunciar a apresentar seus critérios de verdade às outras, porque o diálogo não significa renúncia dos próprios princípios. É importante observar, em relação à possiblidade de comparação entre o cristianismo $\mathrm{e}$ as demais religiões, que a função criteriológico-libertadora da Bíblia seria adequada entre as Igrejas cristãs, podendo, talvez, ser estendida aos judeus. No entanto, com relação às demais esse critério seria inadequado. ${ }^{373}$

O critério de verdade, tendo como objeto as religiões, deve ser verificado em três aspectos: a) o critério ético geral para o ser humano: aplicáveis a todas às religiões, levando em consideração o direito dos povos. Onde critérios éticos universais precisam ser levados em consideração à liberdade de fé, de consciência e de religião. Cabendo a estas liberdades promover, numa escala universal, a liberdade, igualdade, fraternidade e o respeito à dignidade humana. Desta forma, interagem com os direitos e deveres humanos. Este critério permite identificar

\footnotetext{
${ }^{371}$ Cf. Ibid., p. 264-265; 268; 270-271.

372 Aqui Küng, inclui e recusa a proposição do "cristão anônimo" de Karl Rahner, e demais posturas semelhantes.

${ }^{373}$ Cf. Ibid., p. 272-274.
} 
uma religião verdadeira e boa à medida que, ela sirva à humanidade ajudando o ser humano a ser verdadeiramente humano; b) o critério de autenticidade e canonicidade $^{374}$ : um critério religioso geral sobre a originalidade e normatividade aos próprios princípios intrínsecos; c) o critério especificamente cristão: sendo verdadeira e boa quando se deixar sentir o Espírito de Jesus Cristo. ${ }^{375}$

Segundo Küng, só quando uma religião atinge o mais profundo do ser humano $^{376}$ abrindo-o para a questão da verdade de forma radical e existencial. Neste sentido, existe apenas uma verdadeira religião para esta pessoa e, este critério, só pode ser avaliado pela própria pessoa imersa nesta realidade, não podendo a mesma pessoa perceber esta verdade apenas como observadora, pois, se posicionar de forma neutra, acima de todas as tradições, não permitirá descobrir nada em nenhuma delas. ${ }^{377}$. Por este motivo, Küng alega que, o cristianismo é para ele a verdadeira religião e, por conseguir apresentar boas razões em favor desta verdade espera convencer outros. Pois, é onde ele pensa ter encontrado a verdade para sua vida e para sua morte. Porém, isso não significa que as demais religiões tenham que ser falsas, cabendo aos seus teólogos explicar os motivos por ser esta a sua confissão. E por outro lado, cabe aos teólogos cristãos determinar, pelo menos basicamente, o que diferencia cristãos de não-cristãos. Existindo a compreensão que, o único absoluto na história é o próprio Absoluto, para o qual as religiões apontam, e por isso os cristão não creem no cristianismo, mas no único Deus verdadeiro que enviou Jesus de Nazaré como seu Cristo, seu Ungido, sendo este, a regra decisiva. ${ }^{378}$

Cristãos, budistas, islâmicos, hinduístas e todos que anseiam verdadeiramente vivenciar a própria expressão religiosa, necessitam reconhecer que o Absoluto, a realidade última para cada uma dessas expressões, não podem ousar compreender o Incompreensível, nem conhecer o Inescrutável ${ }^{379}$. A verdade, que é Deus, só pode ser conhecida apenas parcialmente e em fragmentos, e somente segundo a capacidade de compreensão de cada momento na história. Todos devem estar conscientes que

\footnotetext{
${ }^{374}$ A partir de fora, isto é, vista de fora, "que apesar de sua ambivalência, ao menos em princípio, correspondem a critérios estabelecidos (ético e religioso): diferentes caminhos de salvação que levam ao mesmo fim, que às vezes se cruzam e sempre podem se enriquecer mutuamente" (Ibid., p. 289).

${ }^{375}$ Cf. Ibid., p. 274-283.

${ }^{376}$ A partir de dentro, isto é, o testemunho e experiência do próprio fiel.

${ }^{377}$ Ibid., p. 285.

${ }^{378}$ Cf. Ibid., p. 284-290.

${ }^{379}$ Cf. 2 Coríntios $13,12$.
} 
estão em caminhada, peregrinando. E nesta jornada, milhões de pessoas de todas as confissões e religiões seguem seu próprio caminho. Nestas condições, todos deveriam estar dispostos de maneira ilimitada a acolher algo de verdade do outro, e comunicar generosamente a própria verdade. ${ }^{380} \mathrm{E}$ devido as dificuldade das diferenças de cultura e linguagem, como agente moderador deste diálogo, o amor deve adentrar onde o entendimento fica de fora. ${ }^{381}$

\section{8}

\section{O ethos mundial para justiça e da paz}

Em seu Projeto de ética mundial, não está em jogo uma ideologia, mas uma práxis que tem como objetivo possibilitar a convivência das pessoas, das famílias e das nações. Neste Projeto, não está em questão a verdade em si, mas valores e posturas éticas, concretas e elementares que estão ao alcance dos seres humanos, independente da orientação espiritual, religiosa ou filosófica. No entanto, se posiciona contra a ditadura do relativismo quanto à ditadura do absolutismo. A prática de convivência que o projeto advoga são as constantes que deveriam estar presentes em todos os lugares, tais como a negação ao assassinato de inocentes, o

\footnotetext{
${ }^{380}$ KÜNG, Hans. Teologia a caminho, op. cit., p. 290-291.

${ }^{381}$ SUDBRACK, Josef. Mística: a busca do sentido e a experiência do absoluto. São Paulo: Loyola, 2007, p. 125. "A salvação do homem é possível fora da Igreja Católica, ou mesmo fora do cristianismo: a questão da verdade e a questão da salvação não são a mesma coisa" (KÜNG, Hans. Religiões do mundo: em busca dos pontos comuns. Campinas: Verus, 2004. p. 282). Diante de tal complexidade o cristianismo não poderá perder o seu centro. Conforme nos orienta o Cardeal Joseph Ratzinger, atual Papa Bento XVI, a ação salvífica de Deus não pode ser generalizada e relativizada de forma arbitrária baseada no lema de que todas as religiões são caminhos de salvação: "A salvação não reside nas religiões como tais, mas depende delas na medida em que as religiões conduzem o homem ao bem único, à procura de Deus, da verdade e do amor. Por isso, a questão da salvação contém sempre um elemento de crítica da religião; tal como se pode relacionar também de modo positivo com as religiões. Em qualquer caso, ela tem a ver com a unidade do bem, com a unidade do verdadeiro - com a unidade de Deus e do homem" (RATZINGER, Joseph. Fé, verdade e cultura. op. cit., 560). No entanto, o cristianismo deverá conseguir articular teológica e coerentemente esta temática urgente e complexa. Uma boa orientação é emitida pelo padre França: onde a ação salvífica de Deus é universal transcendendo épocas, culturas e religiões. E que seu Espírito é derramado em toda humanidade sendo eficaz para salvação de não-cristãos, para possibilitar a capacidade salvífica das religiões não-cristãs e dos não-religiosos, permitindo e capacitando os seres humanos acolherem a orientação fundamental -encontrada objetivamente em Jesus de Nazaré - proporcionada por Deus, como também permitir à todos a reconhecerem o risco do não acolhimento desta orientação. Esta ação salvífica universal pode ser relacionada com a pessoa de Jesus Cristo, sem macular, retirar ou desmerecer a fé dos cristãos nele como mediador e salvador da humanidade. Logicamente, o sentido de missão tradicional passa a ser questionado, porem, não priva a ação missionária de sentido que permitirá apresentar a plena realização e verdade da salvação cristã (Cf. MIRANDA, Mário de França. A salvação de Jesus Cristo. São Paulo: Loyola, 2004, p. 216). Logo, em sua ação missionária, o cristianismo não pode abrir mão da necessidade de corretivo mútuo para que o homem acolha devidamente esta salvação.
} 
abuso de crianças e de mulheres, mentira de governantes e a ajuda aos moribundos. ${ }^{382}$

As quatro diretrizes do Projeto, proclamadas em 1993 no Parlamento das Religiões Mundiais são: a) não violência e respeito a toda forma de vida; b) solidariedade e ordem econômica justa; c) tolerância e lealdade de vida e; d) igualdade de direito entre os sexos. Küng alega que as maiores dificuldades para que estas diretrizes sejam inseridas como paradigma na sociedade ocidental hodierna????-(seria moderna?) trata-se, principalmente, dos libertinos, que não aceitam nenhuma norma ou moral para si, que utilizam o próximo apenas como meio de interesse, e dos governantes, que por meio de mentiras conduzem povos inteiros à guerra. Porém, os grandes escândalos proporcionados pela política, economia e até pela ciência impeliram a constatação de que nem tudo pode ser permitido, sendo prejudicial também para a implantação das diretrizes do Projeto a identificação e associação destas diretrizes com as exigências rigorosas e bem concretas, como as da doutrina moral católico-romana tradicionalista. Logo, recusando estas, tendem também a rejeitar aquelas por identificação e associação. $^{383}$

Uma ética mundial deve se referir aos direitos e deveres humanos. A dignidade humana está em primeiro plano, sendo ela a base da moral da sociedade, independente da fundamentação religiosa, cultural ou pragmáticohumanista das diretrizes do Projeto. O que importa é a convivência de maneira prática, unificando-o em relação às próprias normas e não em relação à fundamentação das mesmas. O Projeto já pressupõe todas as diferenças que de fato existem na sociedade mundial, em perspectiva múltipla, reconhecendo que não é possível eliminar todas as diferenças existentes. O objetivo é a convivência humana pacífica dentro da multiplicidade. A necessidade de um ordenamento democrático deve, para poder funcionar, pressupor valores éticos básicos que ele próprio não pode criar. ${ }^{384}$

\footnotetext{
${ }^{382}$ Conforme entrevista concedida ao Instituto Humanitas Unisinos - IHU Disponível em: http://www.ihu.unisinos.br/entrevistas/10167-a-dignidade-humana-em-primeiro-plano-a-base-damoral-da-etica-mundial-entrevista-especial-com-hans-kueng. Acesso em 28 de abr. 2012. ${ }^{383}$ Cf. Ibid.

${ }^{384}$ Cf. Ibid. A declaração sobre o ethos mundial anunciado no Parlamento das Religiões Mundiais, em 04 de setembro de 1993. Pode ser encontrado em: KÜNG, Hans. Para que um ethos mundial?, op. cit., p. 173-190.
} 
A ausência destes valores na sociedade coloca em xeque a possibilidade dos avanços democráticos. O essencial no projeto de uma ética mundial de Küng segue a constatação da impossibilidade de haver sobrevivência na terra sem uma ética mundial. Não podendo existir paz no mundo sem paz entre as religiões. ${ }^{385} \mathrm{E}$ mais:

Não haverá paz entre as nações sem paz entre as religiões (...) Não haverá paz entre as religiões sem diálogo entre as religiões (...) Não haverá diálogo entre as religiões sem padrões éticos globais (...) Não haverá sobrevivência na Terra com paz e justiça sem que surja um novo paradigma nas relações internacionais, baseado em padrões éticos. ${ }^{386}$

Para fundamentação de um ethos $^{387}$ mundial, a religião deve ser considerada como legítima. No entanto, diante da atual época conturbada e em constante transformação em todas as esferas, a empreitada para o estabelecimento desta ética mundial para a paz entre as religiões e para mundo, trata-se de uma tentativa provisória que se fundamenta na análise das atuais transformações que esboça o surgimento do novo macroparadigma Entendido como termo chave de envergadura histórico-universal. ${ }^{388}$

Mas, com a avalanche de notícias ventiladas sem especificidade pela mídia, parece tornar os indivíduos cada vez mais alheios à realidade que se configura. Fazendo-se necessário que as pessoas sejam atingidas por um conhecimento orientador abrangente:

Este mundo uno não necessita de uma ética básica. Certamente a sociedade mundial não necessita de uma religião unitária, nem de uma ideologia única. Necessita, porém, de normas, valores, ideais e objetivos que interliguem todas as pessoas e que sejam válidos. ${ }^{389}$

Tal empreitada não se trata de uma pretensão político partidária, mas um movimento que leva em consideração o todo da situação mundial, incluindo todas as religiões e confissões cristãs. Não defendendo os conceitos idealistas destas,

\footnotetext{
${ }^{385}$ Cf. KÜNG, Hans. Projeto de ética mundial, op. cit., p. 7.

${ }^{386}$ Id., Para que um ethos mundial?, op. cit., p. 9. Texto de parte da declaração proferida diante do Plenário das Nações Unidas. Disponível nas páginas 7-9, da obra citada.

${ }^{387}$ Küng dá primazia ao termo "ethos" em relação a "ética" por sua maior abrangência que se movimenta em direção a um acordo entre os variados sistemas éticos, postura que não se insere estritamente na ética (Cf. Ibid., p. 26-27).

${ }^{388}$ Id., Projeto de ética mundial, op. cit. p. 8.

${ }^{389}$ Ibid., p. 9.
} 
mas apontando a responsabilidade destas para a paz no mundo. Devendo as religiões acentuar mais os aspectos que as une, e não que as dividem. Mesmo que as religiões e as Igrejas cristãs possam possuir uma boa intencionalidade para colaborar com esta empreitada, com suas exigências éticas, esta colaboração cairá no vazio se não for possível recrutar e conquistar os representantes da política e do mundo econômico-financeiro para este programa. Apesar do projeto se configurar como extraordinariamente complexo, porém, diante da calamidade que se agiganta cada vez mais no cenário mundial como a fome, as doenças, guerras e mortes, torna-se urgente a primazia desta proposta, para poder preservar a esperança de mudança, paz e justiça. É de extrema necessidade a união dos especialistas religiosos e da ética, e dos demais setores da sociedade, tanto prático como teórico, para criar ou sedimentar a consciência de uma ética mundial necessária à sobrevivência da humanidade. ${ }^{390}$

Küng acredita que diante da configuração do novo macroparadigma, as transformações não apontam necessariamente para decadência de valores, mas para uma fundamental transformação de valores e as mesmas podem ser intuídas por diversas transições:

A passagem de uma ciência sem ética para uma ciência eticamente responsável (...) A passagem de uma tecnocracia que domina as pessoas para uma tecnologia que serve à humanidade das pessoas (...) A passagem de uma indústria que destrói o meio ambiente para uma indústria que promove os verdadeiros interesses e necessidades das pessoas em harmonia com a natureza (...) A passagem de uma democracia formalmente de direito para uma democracia vivida, na qual liberdade e justiça estão conciliadas. ${ }^{391}$

\section{9}

\section{Hans Küng e a América Latina}

Qual a aproximação que podemos fazer do pensamento e teologia de Hans Küng em relação à América Latina? Qual a colaboração que podemos extrair de Küng para uma realidade de sofrimento, morte, opressão, pobreza, desumanidade, desrespeito aos direitos e a vida que atinge muitos de seus habitantes? Pode Küng nos apresentar uma visão equilibrada, sincera e profunda, que poderia lançar luz sobre as possíveis respostas para esta realidade socioeconômica e cultural?

\footnotetext{
${ }^{390}$ Cf. Ibid., p. 9-12.

${ }^{391}$ Ibid., p. 46-47.
} 
Como os fenômenos da secularização e da globalização atingem a América Latina, criando problemas sociopolíticos e econômicos, o conceito de ethos mundial de Küng encontra um imenso terreno na busca de sua aplicabilidade. A pluralidade religiosa latino-americana pode usufruir das ideias ecumênicas e do diálogo inter-religioso do teólogo em questão. Da mesma forma, as exposições que caracterizam a postura do cristianismo, tanto institucional quanto individual, em suas próprias fileiras e no relacionamento com sociedade, categoricamente possuem fundamentação para arraigar-se neste solo.

O projeto de ética mundial de Küng é conveniente para a situação socioeconômica, política e cultural da América Latina. Seu projeto pode cultivar interação entre as expressões religiosas e as ideologias seculares, em torno da defesa da vida, do trabalho pela paz, da proteção ao meio ambiente, da cultura da não violência, da solidariedade e da tolerância, e enaltecer o pressuposto de dignidade à vida como fundamento da sociedade. Promovendo com esta ética, a igualdade e mútua colaboração entre homens e mulheres. Propondo uma ética para a religião, economia e a política, capaz de criticar as situações de descasos realmente existentes, e apresentar alternativas construtivas e racionalmente realizáveis, assim como impulsos para a sua realização.

No mundo Latino Americano, a religião ainda possui sua representação na sociedade. Logo, a proposta de orientação cristã para a sociedade ganha enorme valor no contexto latino americano. Como a pastoral cristã poder atuar em sua dupla face de serviços: internos da vida de fé; e externamente, atuando em relação às esferas das necessidades humanas, sociais, políticas, culturais e econômicas. ${ }^{392}$ Esta pastoral, possibilita a esperança para os atores sociais desfavorecidos, que à margem da realidade econômico-social dominante, experimenta situações concretas que lhe fogem ao controle e podem levar ao desespero.

Apesar da forte representação cristã no solo latino americano, existe a urgência de corretivos em diversas concepções desta fé. Correção necessária, principalmente, nos ambientes e confissões que promovem a fé utilitária e que cultivam modos excessivamente imersos na subjetividade. Necessidade que se estende para corrigir o descompasso na relação entre os paradigmas institucionais e individuais. Estas expressões errôneas da fé cristã se fazem presente e possuem

${ }^{392}$ Cf. LIBÂNIO, João Batista. Olhando para o futuro, op.cit., p. 22-26. Nesta obra o autor trabalha diversos aspectos da teologia e da pastoral no contexto latino americano. 
forte representação na mídia, apresentando-se ao grande público com forte apelo. Sendo imperativo que os desvios sejam contornados. Nesta empreitada, as reflexões de Küng proporcionam compreensão para novas motivações, novas ações e um novo sentido, a partir de uma religiosidade autenticamente cristã.

$\mathrm{O}$ cristianismo pode exercer um papel preponderante e fundamental. $\mathrm{Na}$ concepção cristã, no desenrolar da história da humanidade, existe um constante chamamento de Deus à livre responsabilidade humana, diante do sentido último da vida e do outro. O cristão pode colaborar para uma realidade de justiça e liberdade quando vive e auxilia a viver, agir, sofrer e morrer de modo verdadeiramente humano e fecundo de ajuda pelos outros.

No contexto Latino Americano permeado por diversas tradições religiosas é fundamental o diálogo ecumênico entre as tradições cristãs, e prática do interreligioso buscando evitar a reivindicação de superioridade de verdade, de ética e da salvação. Globalmente, as diversas tradições religiosas podem interagir contra todas as manifestações de injustiças e desigualdades que atentam contra a dignidade humana.

Em Hans Küng observamos que as imagens bíblicas, a luz de Jesus de Nazaré, podem se descritas dialeticamente como vida, justiça, liberdade, amor e salvação. Imagens, esperanças e motivação para um povo que é movido pela esperança de novos e melhores tempos.

Em suma, as reflexões de Küng foram cruciais para interpelar e responder as implicações teológico-pastorais que questionam o cristianismo na atualidade. As contribuições deste teólogo proporcionaram a possibilidade de legitimação da existência de Deus, da prática das religiões e do exercício das expressões religiosas, ainda que passíveis de corretivos. Confrontando os abusos dos profetas da pós-modernidade, apresenta que a existência pode ter sentido em seu fundamento, e esta base é encontrada na pessoa e na mensagem de Jesus de Nazaré. Mensagem que pode fornecer orientação para sociedade e desdobrando-se em princípios norteadores para paz entre as religiões e entre as nações. 


\section{5 \\ Conclusão}

Sobre o fenômeno da secularização e seu relacionamento com o cristianismo, diante das perspectivas apresentadas, tudo parece indicar que, a secularização é inexoravelmente um fenômeno necessário e de fato realizado, ou pelo menos em andamento. Apesar do caráter ubiguitário, dos múltiplos atributos semânticos que o termo recebeu, deve ser considerado, objetivamente, como o processo de legitimação e emancipação do poder secular, isto é, da esfera pública em relação ao domínio religioso, reconhecendo a historicidade do mundo. A esfera secular agora emancipada e legitimada, não fundamenta suas ações no divino, nem em qualquer outra ideia que transcenda a ação comum contemporânea dos seres humanos, e não apenas a transcendência religiosa. Logo, no significado original, é um fenômeno historicamente verificável e sem controvérsia. Em outras palavras, foi o processo de secularização da lei e da normatividade jurídica geral que se configurou na construção do Estado moderno.

Este processo teve como consequência o declínio da legitimação religiosa e a saída da religião do espaço público. Porém, nada impede que na condição secular uma sociedade preserve formas religiosas No entanto, não deveria significar a rejeição ou hostilidade à religião, ocorrendo esta dimensão de oposição estamos diante do secularismo e não da secularização.

$\mathrm{O}$ fato interessante é que, a racionalização religiosa impulsionou e desdobrou no desencantamento do mundo implicando na racionalização jurídica, que produziu o desencantamento da lei e a dessacralização do direito, erigindo o moderno Estado laico como domínio da lei. No entanto, secularização e desencantamento não podem ser tomados como sinônimos. Sendo o desencantamento a luta da religião contra a magia, e a secularização a luta da modernidade cultural contra a religião.

No decorrer de toda a história que cobre este processo, verificou-se que a hostilidade entre os proponentes da esfera religiosa e os proponentes da secularização e da racionalização científica, estes, buscando autonomia para investigação do ser humano e do universo, constituiu-se na má interpretação de ambas as partes, iniciada pela esfera religiosa. Tal antagonismo desencadeou um dualismo em chave de oposição entre ciência versus religião e entre fé versus 
razão, sendo está última, um agravamento em relação à primeira, gerando uma crise existencial e colocando em chave de oposição o ser humano versus Deus. Porém, na verdade, não se constitui num confronto entre a essência destas duas esferas, mas sim, num confronto entre as versões equivocadas das mesmas, que extrapolam seus próprios limites intrínsecos e da sua estrita competência, para explicar a existência.

Diante da diversidade das formas religiosas que se instalaram em nossa era secular, e a complexidade do fenômeno religioso e da secularização, leva à compreensão da necessidade de ir além dos autores clássicos que se ocuparam com estas temáticas e que, como todos, estavam sujeitos ao tempo e ao espaço no qual estavam inseridos, confrontando-se com a realidade a ser analisadas diante de seus olhos e sobre influências que podem ter ofuscado alguns aspectos de suas pesquisas. No entanto, sem descartar que, logicamente, são caminhos obrigatórios para compreensão destas duas realidades.

$\mathrm{O}$ intento de ser uma sociedade sem religião ou lança-la à irracionalidade foi, e continua sendo, uma tentativa de catequizar o espírito e a mente humana para tal comportamento, direcionando o desejo de transcendência para outras atividades puramente imanente, até que, as condições forem propícias para a erupção do profundo desejo de ir além do florescimento humano. Mesmo que, esta erupção, tenha culminado numa efervescência religiosa que necessite de corretivos, no caso do cristianismo, à luz dos Evangelhos.

A efervescência religiosa em todas as suas variantes, não é paradoxal e contraditória ao espírito da modernidade, mas, a própria modernidade enquanto tentava eclipsar o religioso, causou uma espécie de saturação e inconformidade com uma vida reduzida ao puro imanente. Logo, o retorno do religioso parece ser paradoxal, quando se tem em mente que a profecia da eliminação da religião, de sua privatização ou à indiferença em relação a ela, fosse inexoravelmente inerente à realidade.

O mundo por seus mistérios, para além da compreensão humana, jamais poderá ser desencantado, nisto ele parece irremediavelmente encantado. Porém, o mesmo parece não se dar com a mente humana que, por árduo aprendizado, poderá levar ao fechamento do self a este mundo, buscando compreende-lo dentro de uma estrutura puramente imanente. 
O universo por sua própria constituição, e o ser humano pela própria limitação diante da realidade do mundo, implica em questionamentos profundos para o ser da existência humana e do universo. Deixar de se interpelar pelo sentido último da existência, é uma forma de desprezar a própria complexidade da realidade e a própria natureza humana.

A secularização é legítima enquanto proposta estrita de racionalização e burocratização da esfera político-jurídica e, como reconhecimento da historicidade do mundo, percebendo o ser humano como agente de transformação no mesmo. Porém, quando apresenta a proposta de ateizar o mundo e deslegitimar em qualquer âmbito a noção de Deus, a transcendência e a religião, tanto quanto relegar e promover propagandisticamente esta esfera à irracionalidade, falha no que lhe é próprio e se mostra ilusória, opinando naquilo que extrapola os seus limites intrínsecos. Isso deveria levar, pelo menos, à intuição de que nenhuma disciplina da esfera secular deveria abdicar de Deus e de toda realidade espiritual, ainda que por liberdade, rejeitasse a se entregar à esta dimensão.

Tudo parece indicar que, o self fechado jamais poderá explorar a potencialidade humana em sua plenitude, já que esta plenitude consiste também em reconhecer os mistérios do mundo e a possibilidade da existência de Deus, como termo para uma explanação final para o sentido primeiro e último dos seres humanos e do universo.

A postura mais adequada não seria de fechamento em qualquer dos extremos, isto é, por um lado, o fechamento no imanente excluindo a possibilidade de Deus e, por outro, o fechamento no transcendente sem reconhecer a historicidade do mundo e o papel humano na construção do mesmo.

Para o esclarecimento da condição humana, a postura secular instrumentalizada e racionalizada do self fechado, demonstrou-se em extrema dificuldade apresentar a razão do ser de toda existência. Por outro lado, o self poroso e intransigente com a realidade imanente teve e terá a mesma limitação.

Não nos encontramos diante de uma secularização que descarte irreversivelmente o religioso, nem diante de uma efervescência religiosa que seja possível reverter a secularização que constituiu a sociedade moderna. Estas duas realidades não podem ser descartadas sem colocar em xeque o que é propriamente 
humano, e ao mesmo tempo o que propriamente de uma sociedade organizada e democrática.

Estamos sim, diante de um mundo que por sua complexidade leva a mente humana a se mover como num tabuleiro de xadrez, buscando resposta para sua inquietude e o ser do mundo, que por sua profundidade na alma humana, poderá levar, como no jogo de xadrez, ao suicídio do seu intelecto, por não suportar a realidade que se encontra a sua frente. Seja esta realidade a irreversibilidade da secularização ou da realidade dos fenômenos religiosos e da religião, em seu sentido stricto, como fundamentada na realidade transcendente de Deus.

O sacrifício do intelecto consta em não aceitar essa dupla realidade como constituinte da própria condição humana, mas, num ato sacrificial ao próprio credo pessoal, descartar ou tomar partido de apenas uma destas esferas, que na realidade não podem ser descartadas. A sabedoria parecer permanecer na possibilidade do equilíbrio, que é desestruturado quando o que deveria caminhar junto e em dialética para o bem da humanidade, é colocado como indiferente, no dualismo em chave de oposição ou jogo de exclusão. Logo, para abordar a religião e os fenômenos religiosos de forma adequada, é necessária uma visão em sua extensão e profundidade.

O cristianismo inserido dentro do contexto do mundo secularizado, não perdeu o seu potencial de anunciar sua mensagem. Podendo despertar a busca pelo sagrado. Buscando, para este objetivo, atingir a sociedade na forma desta se relacionar com o mundo, isto é, reconhecendo que no contexto da cultura da autenticidade enfatiza-se mais a espiritualidade e não o religioso, sendo esta nova configuração distanciada do atual cristianismo.

O cristianismo transcorreu os séculos intrincados às transformações da sociedade. E como qualquer realidade histórica que pretenda perpetuar-se, deve inculturar-se no desenrolar das transformações da história da humanidade, mesmo sem abrir mão de seus princípios fundamentais.

O "tipo ideal” de Taylor com dois extremos de crença e descrença, sendo o espaço entre ambos extremos preenchido por múltiplas opções que assim se configuram e se fragilizam devido às pressões cruzadas. No entanto, este "tipo ideal" pode ser projetado às posturas dentro do próprio cristianismo, isto é por um lado, tende-se à busca de uma autossuficiência nas formas privatizadas do crer e, 
por outro, tende-se buscar a autoridade peremptória das formas tradicionais, sendo que, entre os extremos pode ocorrer a fragilização destas posturas, devido às pressões cruzadas.

Esse "tipo ideal" permite perceber que é possível escapar da "dialética dos extremos", pois existem múltiplas opções e que muito da vida espiritual-religiosa da contemporaneidade se encontra dentro destes espaços.

Nesse contexto de mobilidade, as instituições cristãs poderão passar por um processo de contextualização, e a fé cristã se encontrará num processo de redefinição e recomposição. No entanto, não se pode descartar que, muitos ainda encontrarão sua espiritualidade nas Igrejas tradicionais, que ainda possuem força no mundo moderno, e podendo receber a adesão daqueles que desejam vivenciar momentos em coletividade, podendo este momento ser proporcionado pelas Igrejas cristãs.

Tudo parece indicar que o cristianismo conviverá com pluralidade de expressões religiosas tanto à sua volta quanto em suas próprias fileiras, confrontando-se com o aumento dos que se dizem ateus, agnósticos e os sem religião. Porém, nada indica que a aspiração humana à religião se enfraquecerá no futuro.

Apesar das possíveis mudanças futuras da sociedade, previsíveis ou não, o cristianismo sempre transcendeu às transformações da sociedade, se inserindo neste contexto dinâmico de definição e redefinição, composição e recomposição, necessitando se reestruturar e se contextualizar como sempre fez, e jamais permitiu que Jesus de Nazaré, o Cristo de Deus fosse perdido. Mesmo diante do atual horizonte, que parece apontar para um cristianismo com múltiplas expressões religiosas dentro de suas fileiras, a pessoa de Jesus Cristo por sua presença e memória foi capaz de transcender às culturas e chegar até nós, sendo nossa firme esperança.

Apesar da não eliminação ou arrefecimento da religião na atual sociedade secular, o processo de secularização do Ocidente trouxe em sua esteira múltiplas implicações teológico-pastorais para o cristianismo. Estas implicações necessitam de interpelação e respostas por dois motivos fundamentais: o primeiro, por sua extensão, confrontando o cristianismo ou exigindo do mesmo uma reconfiguração e contextualização; o segundo, por sua profundidade, a capacidade de atingir o ser 
humano em suas raízes ontológicas, ou provocar uma forma deturpação na essência da mensagem cristã. Logo a postura cristã é de confrontação e correção em relação a estas implicações.

No movimento de confrontação e correção, para superação destas implicações, é de fundamental importância, reconhecer os limites da representação da imagem do mundo, como a necessidade da teologia cristã superar o paradigma teológico medieval. Desta forma, a fé cristã e sua teologia poderão apresentar uma linguagem sobre Deus contextualizada e o mais inteligível possível aos seus contemporâneos.

Hans Küng tornou-se fundamental para as reflexões do movimento de superação das implicações teológico-pastorais. Suas contribuições para o cristianismo são notórias. O próprio itinerário de sua vida levou-o a lançar-se sobre as reflexões teológicas, buscando colaborar para que a mensagem do Reino de Deus fosse assimilada por seus contemporâneos, e certamente para gerações futuras. Mesmo polemizando com sua Igreja Mátria e com diversas concepções teológicas tradicionais, sua relevância o coloca entre os baluartes da história da teologia.

Sua concepção da visão integral e da condição do ser humano, que é chamado a exercer com responsabilidade a própria liberdade diante da vida e no seu relacionamento com o outro; seu entendimento da relevância e dificuldades da religião na atualidade; o seu empenho a implantação de um ethos mundial para promoção da justiça e da paz em escala universal; a sua colaboração a favor da compreensão da existência de Deus. Sua escatologia, busca conferir unidade e sentido à história do cosmos e da ação salvadora de Deus. A elucidação proporcionada em suas, são mais que suficientes para imortalizar seu empenho. Diante de sua vultosa dedicação a causa do Reino, as críticas dirigidas a ele, ainda que fundamentadas, jamais poderão atenuar sua importância para o cristianismo. Mesmo buscando uma fundamentação para que a fé cristã tenha motivos racionais para adesão em confiança, não perdeu a sensibilidade em buscar e transmitir a realidade de Deus, que pode tocar o mais profundo do espírito do ser humano, mesmo sobre os radicais efeitos do processo de secularização.

É possível vivenciar a fé cristã na atual sociedade. As questões verdadeiramente religiosas atingem o ser humano em sua totalidade, em sua raiz 
ontológica. Onde podem ser encontrados os referenciais quanto ao princípio e ao fim de todas as coisas, atribuindo sentido à existência do ser humano, à história $\mathrm{e}$ ao universo. Sentido que é atributo da religião, e que a ciência e demais esferas, no máximo podem intuir o que a alma religiosa pode sentir.

A situação religiosa, em seu sentido estrito, envolve esta amplitude na existência humana, e para ser julgada necessita ser avaliada em seus próprios componentes intrínsecos que, intimamente se relacionam com a existência humana. E esta situação religiosa, se torna mais complexa por se julgar estritamente fundamentada no transcendente, desde a Antiguidade, relacionando os seres humanos com Deus ou divino, com o numinoso, o sagrado, a iluminação, a revelação e redenção, sempre remetendo à transcendência. Enquanto a religião se refere aos atos e ritos, tidos como espirituais e que são criações culturais da própria humanidade, para expressar a relação com o sagrado. Por isso deve-se ter o cuidado de não confundir o expresso com aquele que deve ser expresso podendo advir, daqui, toda espécie de confusão.

Com esta complexidade, torna-se no mínimo ambíguo qualquer julgamento fechado e definitivo à religião e aos fenômenos religiosos, que seja realizado observando apenas uma parte do todo, ou tentando avaliar tal complexidade reduzindo-a ao juízo de apenas um saber. Seja este saber a ciência evolucionista, a física com seus métodos cientifico-matemáticos, a química, a biologia, a neurociência, a psicologia, a psicanálise, filosofia ou demais saberes. Todas estas áreas poderão apresentar esclarecimentos de grande importância, porém, não carecem de instrumental adequado que abarque tal complexidade das religiões e dos fenômenos religiosos.

A religião e as expressões religiosas possuem autenticidade e legitimidade, não sendo lícito receber sobre seus ombros o opróbrio de projeção, ópio, ilusão, alienação ou neurose; apesar de muito destas máculas poder existir em diversas expressões da fé. $\mathrm{Na}$ busca da compreensão da mente humana, estas ciências podem colaborar tanto para o teólogo, quanto para o próprio cristianismo. Para existir mútua compreensão entre estas esferas, seus proponentes devem observar seus próprios limites de juízo da realidade, na busca da verdade, tendo como objetivo maior a construção de uma personalidade madura e crítica. 
A vida, em suas diversas esferas que buscam uma explicação para realidade, coadunando com a fé cristã, parece apontar um sentido último, a necessidade de uma explanação final para a existência do ser humano e do universo. Diante da seriedade desta possibilidade e das implicações da utilização da liberdade humana, a ditadura do relativismo e a falta de centro de alguns modos pós-modernos de críticas às posturas mais objetivas, não podem fazer justiça diante da seriedade que deve ser conduzida a vida.

As Igrejas cristãs devem julgar quando é lícita uma reconfiguração institucional, para proporcionar equilíbrio em suas próprias fileiras, e entre fiéis e instituição. Ao mesmo tempo, verificar a licitude de contextualização da teologia, reflexão e da práxis cristã exercida por elas. A necessidade destas constantes ponderações poderá possibilitar as interpelações da cultura e do pensamento hodierno à fé cristã. Ao mesmo tempo, poderá propor uma orientação básica cristã para atual sociedade secularizada. Por sua própria potencialidade, o cristianismo poderá exercer papel preponderante frente à urgência da necessidade de uma teologia ecumênica, no exercício do diálogo inter-religioso e para o estabelecimento de um ethos mundial, com o objetivo de promover a paz entre as religiões e paz entre as nações.

No mundo secularizado e globalizado surge a necessidade de um ethos mundial, pois com a globalização da economia, da tecnologia e das comunicações advém em sua esteira problemas globais que ameaçam o meio ambiente e os seres humanos. Sendo necessário a proclamação, o avanço e a adesão de uma ética global que possa fazer frente às ameaças nucleares, às ações terroristas e que possa permear a mente daqueles que atuam na política, na medicina, na engenharia genética, e demais áreas que no seu exercício se confrontam constantemente com princípios éticos. Além de buscar alcançar todos os setores da sociedade implantando o pressuposto que em primeiro lugar se encontra a dignidade humana. A implantação de um ethos mundial que tem como exigência fundamental que todos os seres humanos sejam tratados humanamente, sinalizando tanto os direitos humanos, quanto os deveres. Coordenado pelas diretrizes de comprometimento com uma cultura de não violência e respeito pela vida; com uma cultura de solidariedade e ordem econômica justa; com a cultura de tolerância e veracidade; com uma cultura de igualdade e companheirismo e 
mutualidade entre homem e mulher. Sendo fundamental para o estabelecimento deste ethos a transformação da consciência, sejam estas religiosas ou não religiosas, e a conversão dos corações.

A teologia, as considerações e reflexões do teólogo suíço-alemão, são cruciais para um mundo em constante transformação, podendo ser aplicadas com legitimidade no contexto latino americano. Por sua relevância, as contribuições de Hans Küng permitirão uma adequada vivência da fé cristã num mundo de secularização.

No mundo encantado, irremediavelmente encantado, a secularização se faz necessária. No entanto, necessária não para desencantar o mundo - o que se mostrou até agora impossível, no máximo se mostrou desencantadora da mente humana - nem para deslegitimar o religioso, mas para encontrar o equilíbrio para que o ser humano possa dar devidamente a César o que lhe pertence, como entregar a Deus o que é de Deus.

Afinal, para o bem da humanidade, tudo o que for verdadeiro, honesto, justo, virtuoso, transparente e com louvor deverá ocupar o pensamento para que a verdadeira esperança na verdade surja. E esta intenção, sendo operada em amor à verdade jamais permitirá confusão.

O perigo maior, mais do que uma sociedade sem Deus e, mais do que o conflito entre ciência e religião e entre fé e razão, é a construção de uma sociedade de homens e mulheres fechados em si mesmos gerando intolerância, violência e radicalizações, provas de desprezo pela própria humanidade que, constituída por seres humanos, para fé judaico-cristã são inexoravelmente feitos à imagem de Deus.

Ser cristão secularizado significa reconhecer e acolher, com consciência crítica e fundamentada nos Evangelhos, os aspectos necessários para a vivência da fé cristã no mundo de secularização. Pode-se dizer que o cristão secularizado vive e anuncia a mensagem de Jesus de Nazaré contextualizada à realidade do tempo em que se vive, hoje, a nossa era secular. Reconhecendo a historicidade do mundo e a própria postura do ser humano e do cristão como agentes históricos e transformadores no mundo, ainda assim, tendo Deus como fundamentação última da própria existência. Vivendo a realidade, do sim e do ainda não, do Reino de Deus, sem detrimento dos aspectos da natureza humana, como também sem 
detrimento do Reino. Tendo como paradigma Jesus de Nazaré, para viver o equilíbrio entre imanência e transcendência. Sendo relevante para ajudar o ser humano a superar sua própria ambiguidade, na construção de sua personalidade e de uma civilização que tenha amor pela verdade e amor pelos seus semelhantes.

O cristão secularizado e o cristianismo, caminhando sobre as pegadas de Jesus de Nazaré, podem apresentar não como imposição, mas como proclamação e convite, o sentido fundamental e último da existência humana em todos os tempos e culturas, restituindo ao ser humano, mesmo no mundo de secularização, qualidades e dignidades mais profundas, possibilitando o aprofundamento ou redescoberta do sagrado. 


\section{6}

\section{Referências Bibliográficas}

\section{Obras de Hans Küng}

A Igreja Católica. Rio de Janeiro: Objetiva, 2002.

¿Existe Dios? Respuesta al problema de Dios en nuestro tiempo. 4. ed. Madrid: Ediciones Cristandad. 1979.

. Freud e a questão da religião. Campinas: Verus Editora, 2006.

. Ser Cristiano. 3.ed. Madrid: Edições Cristandade, S.L, 1977.

O princípio de todas as coisas: ciências naturais e religião. 2. ed. Petrópolis: Vozes, 2009.

. O que deve permanecer na igreja. Petrópolis: Vozes, 1976.

. Para que um ethos mundial? Religião e ética em tempos de globalização. Conversando com Jürgen Hoeren. São Paulo: Loyola. 2005.

Por que ainda ser cristã hoje? Campinas: Verus Editora, 2004.

Projeto de ética mundial: uma moral ecumênica em vista da sobrevivência humana. 4. ed. São Paulo: Paulinas, 2003. 2004.

Religiões do mundo: em busca dos pontos comuns. Campinas: Verus,

Teologia a caminho: fundamentação para o diálogo ecumênico. São Paulo: Paulinas, 1999.

Teología para la postmodernidad: Fundamentación ecuménica. Madrid: Alianza Editorial, 1989.

\section{Demais obras}

ARNOULD, Jacques. A teologia depois de Darwin. São Paulo: Loyola, 2001.

BERGER, Peter L. A dessecularização do mundo: uma visão global. In: Religião e Sociedade, vol. 21, nº. 1, 2000.

The Desecularization of the World: A global overview. In: Berger (org), The Desecularizaton of the World: Resurgent Religion and World Politics. Grand Rapids MI: Ethic and Politic Policy Center and W. B. Eerdmans Publishing Company, 1999. 
O dossel sagrado: elementos para uma teoria sociológica da religião. São Paulo: Paulinas, 1985.

BERGER, Peter; BERGER, Brigitte; KELLNER, Hansfield. The Homeless Mind: Modernization and Consciousness. Nova Iorque: Vintage Books, 1973.

BÍBLIA. Português. Bíblia de Jerusalém. São Paulo: SOCIEDADE BÍBLICA CATÓLICA INTERNACIONAL e PAULUS, 1995.

BOFF, Lina. Da esperança à vida plena em Cristo: vivendo as realidades que entrevemos. Juiz de Fora: Editar Editora Associada, 2010.

BOLAN, Valmor. Sociologia da Secularização: a composição de um novo modelo cultural. Petrópolis: Vozes, 1972.

BRAGUE, Rémi. La Sagesse du Monde. Paris: Fayard, 1999. BRAGUE, Rémi. Edição em português: A sabedoria do mundo. São Paulo: Instituto Piaget, 2000.

BREUNING, Breuning. Gericht und Auferweckung von den Toten ais Kennzeichen des Vollendungshandeln Gottes durch Jesús Christus. en J. Feinery M. Lóhrer (edit.). Zurich: Mysterium Salutis, 1976, V, 882.

MARIZ, Cecília Loreto. Mundo moderno, ciência e secularização. In: FALCÃO, Eliane Brígida Morais (Org.). Fazer ciência, pensar a cultura: estudos sobre as relações entre ciência e religião. Rio de Janeiro: UFRJ, 2006.

. Secularização e dessecularização: comentários a um texto de Peter Berger. In: Religião e Sociedade, vol. 21, nº 1, 2000.

COMBLIN, José. Mitos e realidade da secularização. São Paulo: Herder, 1970. Comissão Teológica Internacional.

COX, Harvey. A cidade do homem. Rio de Janeiro: Paz e Terra, 1971.

DAWKINS, Richard. Deus: um delírio. São Paulo: Companhia da Letras, 2007.

DELUMEAU, Jean. História do medo no ocidente 1300-1800: uma cidade sitiada. São Paulo: Companhia das Letras, 2009.

DONDEYNE, Albert; FRIES, Heinrich, et al. Ateísmo e secularização. Caxias do Sul: Paulinas, 1970.

DURKHEIM, Émile. As formas elementares da vida religiosa. São Paulo: Martins Fontes, 2003.

ELIADE, Mircea. O sagrado e o profano. São Paulo: Martins Fontes, 1992.

FERRY, Luc; GAUCHET, Marcel. Depois da religião: o que será do homem depois que a religião deixar de ditar a lei? Rio de Janeiro: DIFEL, 2008. 
FEUERBACH, Ludwig. A essência do cristianismo. Campinas: Papirus, 1988.

FREUD, Sigmund. Os pensadores. São Paulo: Abril S/A cultural e Industrial, 1978.

GARCIA, Alfonso Rubio; AMADO, Joel Portela (Orgs). Fé cristã e pensamento evolucionista: aproximações teológico-pastorais a um tema desafiador. São Paulo Paulinas, 2012.

GAUCHET, Marcel. Le désenchantement du monde. Paris: Gallimard,1985.

GIBELLINI, Rosino. A teologia do século XX. 2. Ed. São Paulo: Loyola, 2002.

GOGARTEN, Friedrich. Verhängnis und Hoffnung der Neuzit. Die Säkularisierung als theologisches Problem. Muenchem/Hamburg: Siebenstern Tascchenbuch Verlag, 1966. Publicada primeiramente em 1953.

GONDIM, Ricardo. O evangelho da nova era: Uma análise e refutação bíblica da chamada teologia da prosperidade. 3 ed. São Paulo. ABBA, 1995.

HABERMAS, Jürgen. The structural transformation of the public sphere. Cambridge, Mass: MIT Press, 1989. Edição portuguesa: Mudança estrutural da esfera pública. 2.ed. Rio de Janeiro: Tempo Brasileiro, 2003.

; RATZINGER, Joseph. Dialética da Secularização: sobre razão e religião. Aparecida: ideia e Letras, 2007.

HAUGHT, J. F. Deus após Darwin: uma teologia evolucionista. Rio de Janeiro: José Olympio, 2002.

HEELAS, Paul. The New Age Moviment. Oxford: Blackwell, 1996.

HERVIEU-LÉGER, Danièle. O peregrino e o convertido: a religião em movimento. Petrópolis: Vozes, 2008.

HUNTINGTON. Samuel. O Choque de civilizações: e a recomposição da Ordem Mundial. Rio de Janeiro: Objetiva, 1997.

KENNEDY, D. James; NEWCOMBE, Jerry. E se Jesus não tivesse nascido? São Paulo: Editora Vida, 2003.

KUHN, Thomas. A estrutura das revoluções científicas. São Paulo: Perspectiva, 1978 .

LA DUE, Willian J. O guia trinitário para escatologia. São Paulo: Loyola, 2007.

LIBÂNIO, João Batista. Olhando para o futuro. Prospectivas teológicas e pastorais do cristianismo na América Latina, São Paulo: Loyola, 2003. 
MARIANO, Ricardo. Neopentecostais: sociologia do novo pentecostalismo no Brasil. São Paulo: Loyola, 2005.

MARRAMAO, Giacomo. Céu e terra: genealogia da secularização. São Paulo: UNESP, 1997.

MARTELLI, Stefano. A religião na sociedade pós-moderna: entre secularização e dessecularização. São Paulo: Paulinas, 1996.

MARX, Karl. Manuscritos econômicos e filosóficos. São Paulo: Martin Claret, 2001.

MENDONÇA, Antônio Gouvêa; FILHO, Prócoro Velasques. Introdução ao Protestantismo no Brasil. 2. ed. São Paulo: Loyola, 2002.

MIRANDA, Mário de França. A salvação de Jesus Cristo. São Paulo: Loyola, 2004. tempos.

Igreja e sociedade. São Paulo: Paulinas, 2009, p. 6-7- Coleção sinais dos Loyola 1996.

Um homem perplexo: o cristão na atual sociedade. 3.ed. São Paulo: MOLTMANN, Jürgen. Teologia da esperança: estudos sobre os fundamentos e as consequências de uma escatologia cristã. São Paulo: Editora Teológica, 2003.

NIETZSCHE, Friedrich .Ecce Homo. São Paulo: Martin Claret, 2000.

A gaia ciência. São Paulo: Companhia das letras, 2001.

Assim falou Zaratustra. São Paulo: Martin Claret, 2000.

NOLAN, Albert. Jesus hoje: uma espiritualidade de liberdade radical. São Paulo: Paulinas, 2008.

OAKLEY. Francis. Kingship. Oxford: Blackwell, 2000.

PIERUCCI, Antônio Flávio. O desencantamento do mundo: todos os passos de um conceito. São Paulo: Editora 34, 2003.

. Secularização em Max Weber. Da contemporânea serventia de voltarmos a acessar aquele velho sentido. Revista Brasileira de Ciências Sociais, v. 13, n. 37, jun. 1998.

; PRANDI, Reginaldo. A realidade social das religiões no Brasil. São Paulo: HUCITEC, 1996. 
RATZINGER, Joseph. Fé, verdade e cultura: reflexões a propósito da encíclica Fides et Ratio I. In: COMMUNIO. Revista Internacional Católica. Ano XVI, n. 5, out.1999.

Introdução ao cristianismo: preleções sobre o Símbolo Apostólico. São Paulo: Herder, 1970.

RIEDL, Rupert. Die Strategie de Genesis: naturgeschichte der realen welt. Munique, 1976.

ROMEIRO, Paulo. Supercrentes: o evangelho segundo Kenneth Hagin, Valnice Milhomens e os profetas da prosperidade. 6. ed. São Paulo: Mundo Cristão, 1998. Para uma leitura sociológica desta realidade:

RUBIO, Alfonso García. Unidade na Pluralidade: o ser humano a luz da fé e da reflexão cristãs. São Paulo: Paulus, 2001.

A visão científica evolucionista interpela a fé em Deus criador. In:

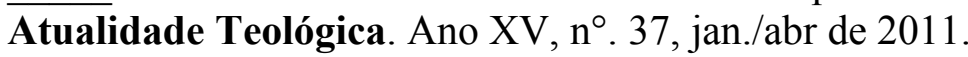

; AMADO, Joel Portela. Fé cristã e pensamento evolucionista. São Paulo: Paulinas, 2012, p.

SEGUNDO, Juan Luís. Que mundo? Que Homem? Que Deus? Aproximações entre ciência, filosofia e teologia. São Paulo: Paulinas (Coleção Teologia Atual) 1995.

SHELDRAKE, Philip. Espiritualidade e teologia: vida cristã e fé trinitária. São Paulo: Paulinas, 2005.

SUDBRACK, Josef. Mística: a busca do sentido e a experiência do absoluto. São Paulo: Loyola, 2007.

TAYLOR, Charles. Uma era secular. São Leopoldo: UNISINOS, 2010.

THILS, Gustave. Cristianismo sem religião? Petrópolis: Vozes, 1969.

VATIMMO, Gianni. Depois da cristandade: por um cristianismo não religioso. Rio de Janeiro: Record, 2004.

VEYNE, Paul. Quando nosso mundo se tornou cristão: 312-394. Rio de Janeiro: Civilização Brasileira, 2010.

WEBER, Max. A ética protestante e o espírito do capitalismo. São Paulo: Pioneira, 1999.

Rejeições religiosas do mundo e suas direções. In:__Ensaios de Sociologia. Rio de Janeiro: Zahar Editores, 1979.

ZILLES, Urbano. Filosofia da religião. São Paulo: Paulus, 1991. 


\section{7 \\ Sites Web apresentados}

\section{Instituto Humanitas Unisinos - IHU}

http://www.ihu.unisinos.br/entrevistas/10167-a-dignidade-humana-em-primeiroplano-a-base-da-moral-da-etica-mundial-entrevista-especial-com-hans-kueng. Acesso em: 28 e abr. 2012.

http://www.ihu.unisinos.br/entrevistas/9010-o-projeto-de-etica-mundial-de-hans$\mathrm{k} \% \mathrm{C} 3 \% \mathrm{BCng}$-entrevista-especial-com-manfredo-araujo-de-oliveira. Acesso em: 28 de abr. 2012.

http://www.ihu.unisinos.br/noticias/40194-a-igreja-precisa-de-pessoas-comohans-kueng-e-bento-xvi. Acesso em: 28 de abr. 2012.

http://www.ihu.unisinos.br/noticias/40253-o-olhar-critico-e-necessario-de-hanskueng. Acesso em: 28 de abr. 2012.

http://www.ihu.unisinos.br/noticias/40287--hans-kueng-ratzinger-se-converteuem-papa-tornando-se-certamente-mais-falivel. Acesso em: 28 de abr. 2012.

http://www.ihu.unisinos.br/noticias/noticias-arquivadas/20555-a-verdade-de-hansküng. Acesso em: 28 de abr. 2012.

http://www.ihu.unisinos.br/noticias/noticias-arquivadas/26676-\%60\%60vivi-setevidas-nao-tenho-medo-de-morrer $\% 60 \% 60$-entrevista-com-hans-k\% $\% 3 \% \mathrm{BCng}$. Acesso em: 28 de abr. 2012.

http://www.ihu.unisinos.br/noticias/noticias-arquivadas/32183-tenho-simpatiapelo-homem-joseph-ratzinger-entrevista-com-hans-kueng. Acesso em: 28 de abr. 2012.

http://www.ihuonline.unisinos.br/index.php?option=com_content\&view=article\&i $\mathrm{d}=2458 \&$ secao $=288$. Acesso em : 28 de abr. 2012.

\section{Demais sites}

PIERUCCI, Antônio Flávio. Secularização em Max Weber. Da contemporânea serventia de voltarmos a acessar aquele velho sentido. http://www.scielo.br/scielo.php?script=sci_arttext\&pid=S0102909199800020000 $3 \& \operatorname{lng}=$ pt\&nrm $=$ iso $>$. Acesso em: 29 abr. 2012.

http://www.teleios.com.br/2011/hans-kung-teologo-alemao-questiona-eatificacaode-joao-paulo-2\%C2\%B0/. Acesso em: 29 de abr. 2012. 